\title{
Elaborations: A Selective Annotated Bibliography of Reviews and Commentaries on the Poetry and Short Stories of Bill Manhire from 1967 to 2002.
}

\author{
by \\ Laurinda Elizabeth Thomas \\ Submitted to the School of Information Management, \\ Victoria University of Wellington \\ in partial fulfilment of the requirements for the degree of \\ Master of Library and Information Studies
}

10 February 2003 


\section{Acknowledgements}

I would like to acknowledge the assistance and support of the following people in completing this bibliography: Rachel Lilburn, Cameron McIntosh, Lindsay Corleison, Tony Cuttriss, Pauline LaRooy, Avril Loversidge.

I would also like to acknowledge the time given to be by Bill Manhire to allow me to discuss this project with him. 


\section{Table of Contents}

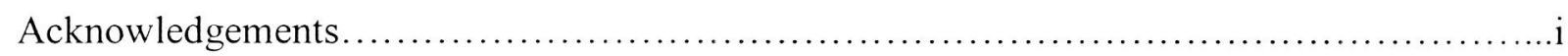

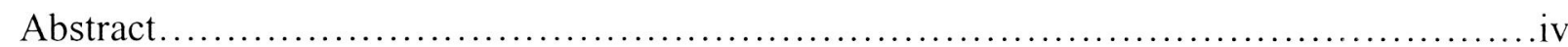

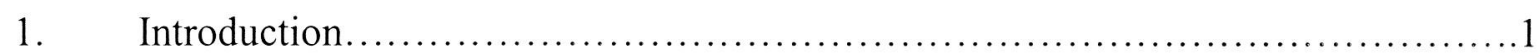

2. The Need for Bibliographic Coverage.........................................

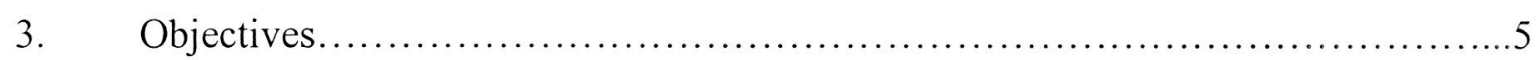

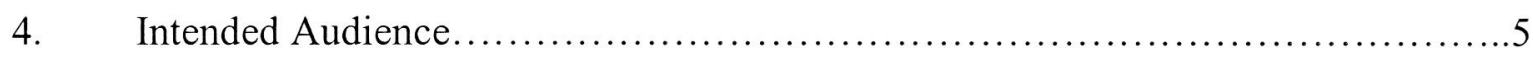

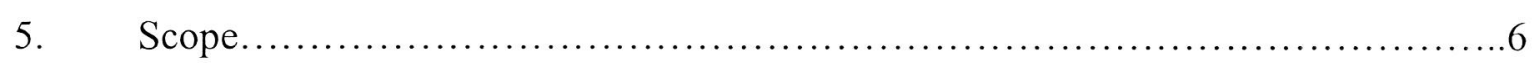

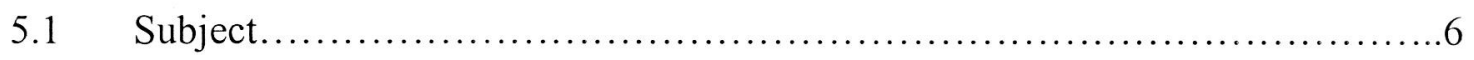

$5.2 \quad$ Material Types..................................................... 7

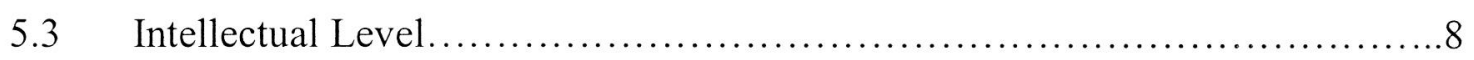

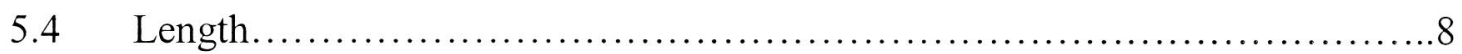

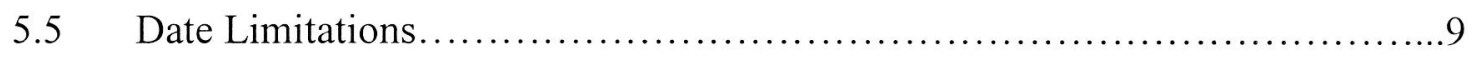

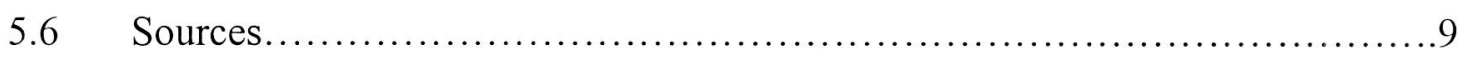

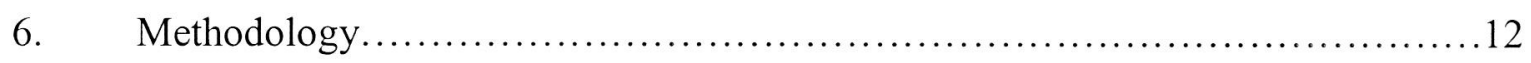

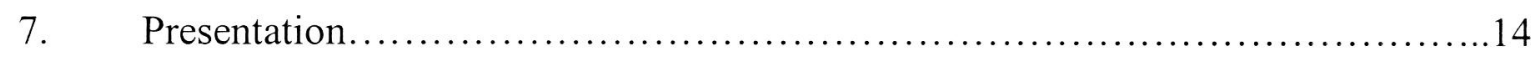

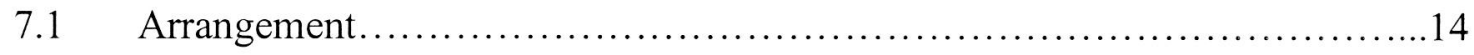

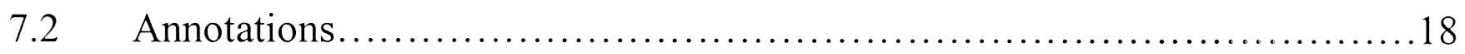

7.3 Appendices................................................... 18

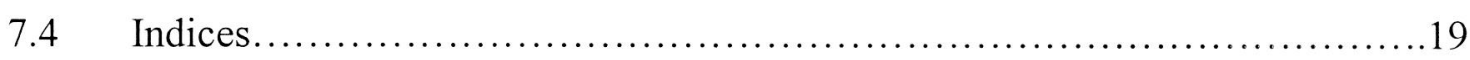

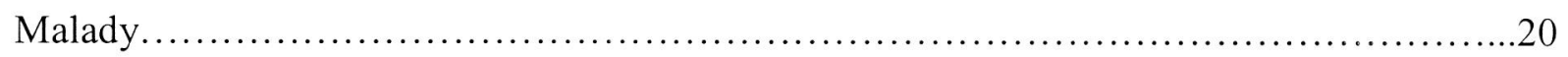

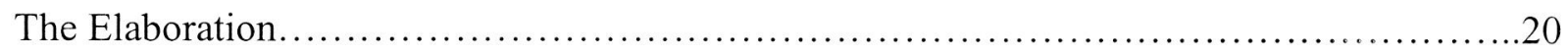

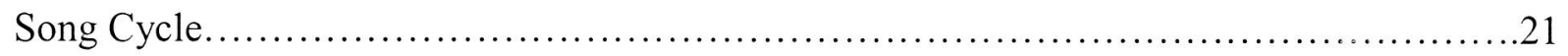

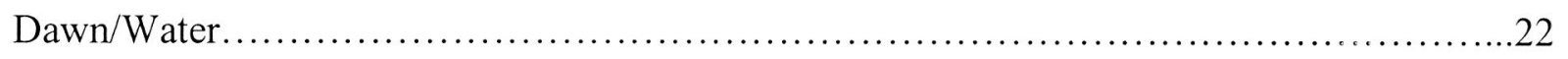

How to Take Your Clothes Off at the Picnic......................................22

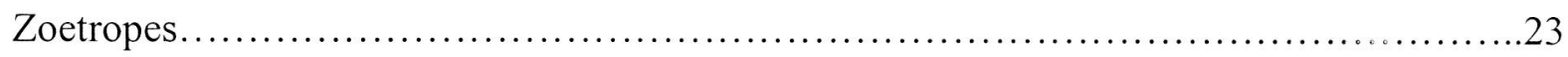


Good Looks.

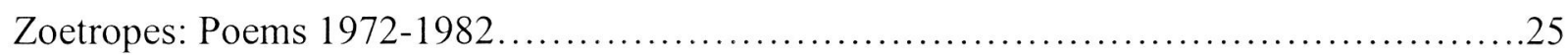

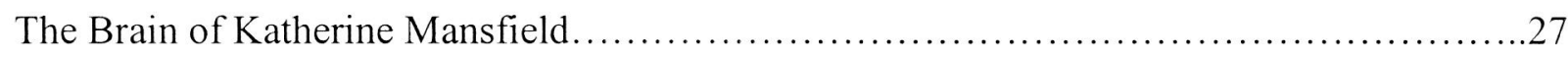

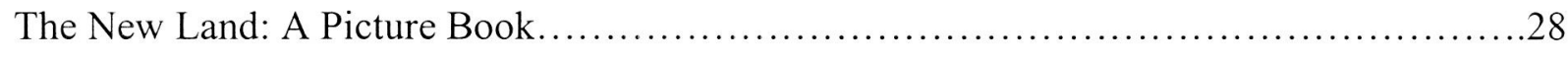

The Old Man's Example......................................................... 32

Milky Way Bar.............................................................. 32

An Amazing Week in New Zealand ............................................. 34

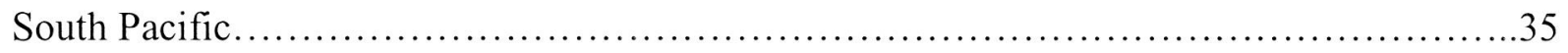

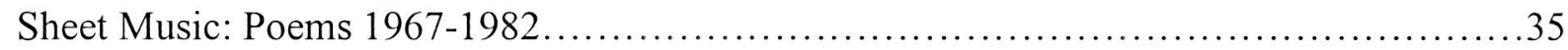

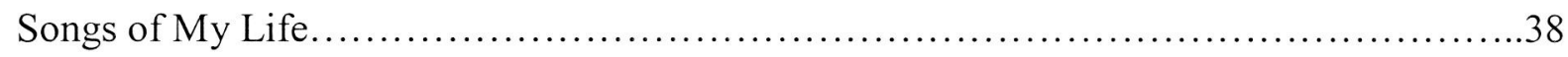

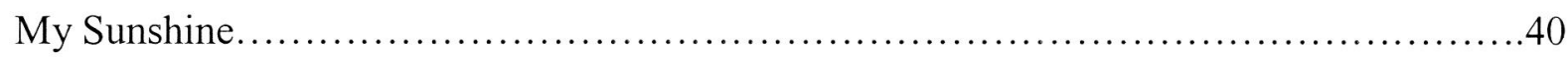

Homelight: an Antarctic Miscellany.............................................41

What to Call Your Child ....................................................42

Collected Poems..........................................................44

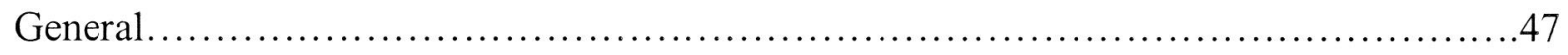

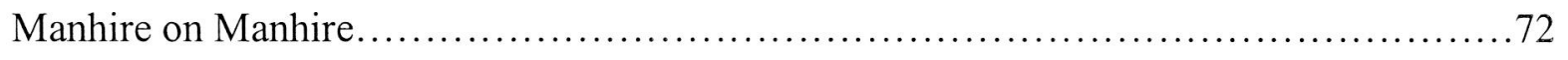

Appendix A: Reference for items which have not been sighted......................76

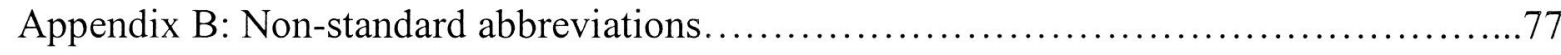

Appendix C: Bibliography to the Introduction.....................................

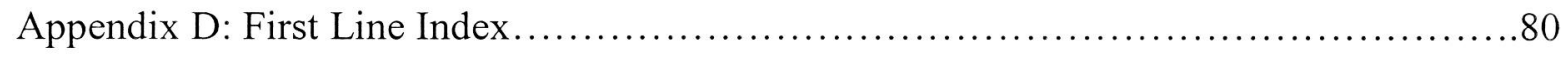

Appendix E: Poem Title Index ................................................. 86

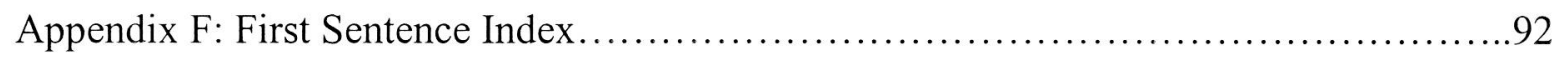

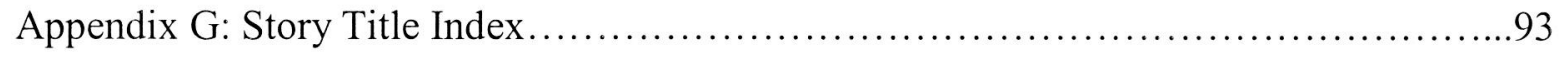

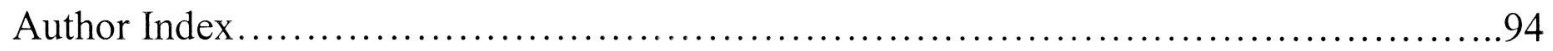

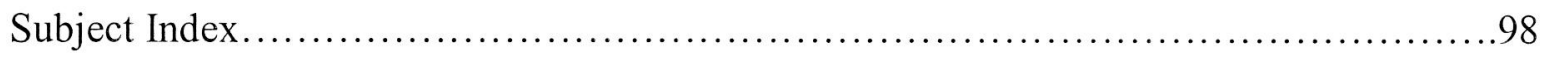




\begin{abstract}
Bill Manhire is one of New Zealand's most well-known writers, with a career that spans more than 30 years. His work has received little bibliographic attention, with available resources being incomplete or providing minimal descriptions.

This bibliography aims to redress this gap in coverage through the inclusion of additional media types such as archives, encyclopaedia extracts, sound and video recordings, and web pages. In addition, it adds value to previous work done in this area by correcting errors, providing additional bibliographic information, and annotations.

Citations and annotations are included for all items which fulfil the aim of providing significant comment on, or insight to the poetry and short stories of Bill Manhire. Citations are grouped by collection title, general works, and pieces written by Manhire himself. This bibliography will be useful to researchers, students, journalists and interested members of the public.
\end{abstract}

\title{
Key words
}

Bill Manhire

Poetry

Poet

Short Stories

New Zealand

Bibliography

Word Count: 23,803 


\section{Introduction}

Bill Manhire (1946- )

Bill Manhire has been a significant force in New Zealand literature from the early 1970's.

His literary career has spanned more than three decades thus far, making contributions to a multitude of genres, most significantly poetry. "The winner of many literary prizes...

he is recognised as among the two or three finest New Zealand poets of his generation." 1

Bill Manhire was born in Invercargill in 1946. He studied at the University of Otago and University College, London ${ }^{2}$, and took up a lectureship in the English Department at Victoria University of Wellington in 1973. In 2000, he became the director of the International Institute of Modern Letters (IIML), under whose auspices the creative writing programmes are run.

His works have been recognised through a host of awards, including the New Zealand Book Award (later the Montana New Zealand Book Award) for Poetry in 1978, 1985, 1992 and 1996, being appointed the first Te Mata Poet Laureate in 1997, and having his Collected Poems 1967-1999 published simultaneously by Victoria University Press and Carcanet in the United Kingdom.

Bill Manhire's contributions to the canon of New Zealand literature have been recalled frequently and reviewed often. The sheer number of interviews with the author, and commentaries reflect the amount of attention that is paid to his work. However, bibliographic work done in the area to date has been little, and of uneven quality. The

\footnotetext{
${ }^{1}$ New Zealand Book Council, MANHIRE, Bill (17 May 2002).

http:/www.ruw ac.nz/nbookeouncil/writers/manhireb.htm [Accessed 19 June 2002]

${ }^{2}$ Harvey McQueen and Lois Cox, Ten modern New Zealand poets (Auckland: Longman, 1974), 188.
} 
bibliographies that do exist of Manhire's work have had few or no annotations, are frequently badly referenced (with notable omissions of authors, titles, dates, and even whole collaborative efforts), and do not include archival collections, audiovisual recordings, internet resources, book chapters and excerpts, and unindexed literary journals, student newspapers and magazines.

In view of these points, made above, this research has endeavoured to render a more comprehensive annotated bibliography for the use of those with an interest in New Zealand literature, Bill Manhire, the poetry and short story genres, and the literary tradition in New Zealand.

\section{The need for bibliographic coverage}

The bibliographer need not think that the existence of a bibliography of a subject already necessarily renders further work in that direction valueless.

Augmentation and improvement is often possible. ${ }^{3}$

The availability of current bibliographic literature indicates a need for comprehensive studies of the works of New Zealand authors. Ralph C. Crane comments that

With the recent burgeoning interest in post-colonial literatures in universities around the world, and particular the growing interest in New Zealand literature in countries like Australia and Canada, among others, the need for collections of essays on single New Zealand authors, to complement the often very fine general collections of essays on New Zealand literature, seems to me apparent. ${ }^{4}$

\footnotetext{
${ }^{3}$ A. M. Lewin Robinson, Systematic Bibliography: A Practical Guide to the Work of Compilation (London: Clive Bingley, 1979), 34.

${ }^{4}$ Ralph C. Crane, Ending the silences: critical essays on the works of Maurice Shadbolt (Auckland: Hodder Moa Beckett, 1995), ix.
} 
This research brings together references not only to the essay-type material on Bill Manhire's work, but also the wide variety of other resources available that comment on the poetry and short stories of this author.

Previously, the options for researchers investigating Bill Manhire contained a variety of impediments to providing the information required. A large site is maintained by the Auckland University Library covering the works of New Zealand authors. On its page devoted to Bill Manhire ${ }^{5}$, items are divided by the works to which they refer (under which book reviews are placed), items edited by Bill Manhire, articles written by Bill Manhire, and articles about Bill Manhire. Last updated to January 2002, it includes works from 1970 onwards. It is useful as an introduction to the topic, covering all the journals indexed on Index New Zealand, and placing single items into more than one category, depending on its content. The bibliography contains several omissions, however. The reviews do not have titles listed, despite most reviews having them. This makes retrieval awkward, particularly if items are to be obtained through inter-library loan. Reviews under book headings are listed by date of publication rather than alphabetically, making looking for a particular reviewer or commentator time-consuming. The form of referencing is sometimes confusing to read in regards to differentiating volume numbers from page numbers. Omissions are also made; for example, it does not mention Song Cycle by Jack Body and John Casserly, which uses Bill Manhire's poetry ${ }^{6}$. Some commentaries on the piece examine the poetry used; however, this contribution is

\footnotetext{
${ }^{5}$ The University of Auckland Library: Te Tumu Herenga, Bill Manhire. http:/www2.auckland.ac nz/br/mzp/nzlit2/manhire.htm [Accessed 14 July 2002]

${ }^{6}$ Avril Jean Loversidge, "A Select Bibliography of Writings about Jack Body and his Compositions between 1965 and 2000" (Master of Library and Information Studies, Victoria University of Wellington, 2001), 26-30, 66.
} 
not recorded by Auckland's bibliography. Annotations are brief to non-existent in this resource. As Krummel notes, "there are very few bibliographies that would not benefit from annotations to their entries." 7

The other main resource for researchers is Index New Zealand. The material covered is largely similar to the Auckland bibliography, but with more detail. Index New Zealand is updated daily and indexes a range of publications from New Zealand and overseas. Coverage starts in 1987. Before this researchers must refer to Index to New Zealand Periodicals.

This resource is useful in the amount of detail given in regard to each item; for example, the full title of the article, subject and note headings (most commonly used to denote 'Book review' or 'Poetry', for example). The layout is much clearer, although there are some formatting inconsistencies in page number layout. A short abstract of each item is also given; however, this varies in quality from a simple statement (e.g. "REVIEW OF Milky Way Bar), to a summary of the material. As in the Auckland bibliography, there is no attempt to detail specific poems mentioned in the material. Neither includes any references to archival material, Internet resources or book extracts, for example.

The main limitation of Index New Zealand is the need to be very specific when searching. A general search on 'Bill Manhire' will generate several hundred hits. However, if a search is made only on a title that is specifically of interest (Dawn/Water

\footnotetext{
${ }^{7}$ D.W. Krummel, Bibliographies: Their Aims and Methods (London: Mansell Publishing Limited, 1990), 75.
} 
for example) other material of interest contained in interviews and general commentaries on his work is likely to be overlooked.

This research addresses the gaps and weaknesses in these resources, as well as identifying content in other formats; in particular, monographs, electronic information, and sound and video recordings. It will improve access through the provision of annotations. By so doing, this research builds on what has previously been done, making access easier and providing more comprehensive coverage of the available literature on the subject.

\section{Objectives}

- To facilitate access to relevant primary and secondary material that has not as yet been indexed, particularly in Wellington and Dunedin where the author has spent significant portions of his life;

- To build on the work of previous research in this area by addressing weaknesses in format and coverage;

- To provide a useful resource to those researching, studying or interested in New Zealand poetry and short stories, and/or Bill Manhire, by providing annotations for each item stating details such as poems cited, and themes and techniques mentioned where appropriate.

\section{Intended Audience}

This bibliography is most likely to be useful to the following user groups:

- Researchers of New Zealand literature, poetry and/or short stories; 
- Students and teachers at tertiary level;

- Students and teachers at secondary level;

- Researchers investigating particular themes in New Zealand literature;

- Speech and drama students;

- Journalists;

- Members of the general public with an interest in New Zealand literature, poetry, short stories and/or Bill Manhire's career.

\section{Scope}

The bibliography includes material in any format that reviews, evaluates, critiques or provides background to the poetry and short stories of Bill Manhire. Due to restricted resources and time, the following limitations have been applied:

\subsection{Subject}

This bibliography includes the following subject areas:

- Biographical information on Bill Manhire where it gives comment on or insight to his short stories and/or poetry;

- Reviews of the poetry and short stories of Bill Manhire;

- Commentaries on the poetry and short stories of Bill Manhire.

This bibliography does not include:

- Annotations for the actual poetry and short story collections themselves; 
- Writings by Bill Manhire, except where they make specific comment or provide insight into his own poetry or short stories;

- Writings from other authors who do not make substantial comment on Bill Manhire's poetry or short stories (for example, general overviews of New Zealand poetry).

\section{$\underline{5.2}$ Material Types}

This bibliography includes the following media and format types:

- Books or parts thereof;

- Periodical articles, reviews and commentaries;

- Newspaper articles, reviews and commentaries;

- Audio recordings;

- Moving images;

- Archives (unrestricted);

- Theses;

- Webpages.

Advertising and promotional material is not included. Due to its stated purpose and subsequent bias, it is unlikely that this material would include substantial critical commentary of value to the researcher.

Material is restricted to that written in the English language, due to the time and cost restrictions of translations. Due to these restrictions of time and cost, material has 
been limited to that which can be obtained within New Zealand, with the exception of items that can be sourced through document delivery systems such as Ariel.

As Bill Manhire spent time in 1999 on a Fulbright Scholarship at Georgetown University in Washington DC, significant relevant material published in the United States may not be listed in this bibliography due to the time and cost involved in identifying and accessing these resources. References to items that were identified but could not be obtained are cited in the appendix.

\section{$\underline{5.3 \text { Intellectual level }}$}

Items in this bibliography include material suitable for young adults (teenager) and upwards, where the material offers suitable comment on the poetry and short stories of Bill Manhire. This bibliography does not include material suitable for children (intermediate age or younger). The bibliography is aimed at the level of the user groups previously stated.

\subsection{Length}

Items have been accepted or rejected for inclusion on the basis of their content and its applicability to the subject and scope. No minimum or maximum word limits on items have been imposed. 


\section{$\underline{5.5 \text { Date Limitations }}$}

Material was looked for between the dates of 1946 (the birth of Bill Manhire) to the present day. However, particular emphasis was placed on searching sources from 1967 onwards, being the start of his working career (as indicated by his Collected Poems 1967-1999).

\section{$\underline{5.6 \text { Sources }}$}

The following sources were searched during this research:

- Te Puna (National Bibliographic Database and Archive);

- Index to New Zealand Periodicals 1941-1986;

- Index New Zealand (INNZ) 1987-

Index New Zealand indexes significant publications for this research including:

- Arts \& Community

- Dominion

- Dominion Post

- Evening Post

- Islands

- Journal of New Zealand Literature

- Landfall

○ Metro

- New Zealand Books

- New Zealand Herald

- New Zealand Listener 

- North and South
- Press
- Quote Unquote
- Times Literary Supplement

- Newstext INL;

- Reuters;

- Unindexed material was searched manually from 1967, including:
- Arts Times
- Cave
- Common Tatta
- Critic
- Illusions
- JAAM
o Kite
- Meanjin
- Morepork
- Numbers
- NZU Arts Festival Yearbook
- Poetry New Zealand
- Printout
○ Rambling Jack
- Salient
- Southerly 

- Spin
- Spleen
- Sport
- Stand
- Stout Centre Review
- Takahe
- Westerly

- General reference works on:
○ New Zealand poetry;
- New Zealand short stories;
- New Zealand literature.

- Who's Who works;

- Union list of Higher Degree Theses;

- Indices to Literary Criticism;

- Archives held at:

- Alexander Turnbull Library (Wellington);

- Archives New Zealand (Wellington);

- Radio New Zealand Sound Archives;

- TVNZ Archive;

- Webpages using the following search engines:
○ http://www.google.co.nz;
- http://nz.altavista.com;
○ http://www.engines2go.com/nz/. 
- Catalogues of University Libraries in New Zealand;

Any items located were checked for any further bibliographic references.

\section{Methodology}

The following Library of Congress subject headings were used:

- Manhire, Bill, 1946 -

- Manhire, Bill, 1946 - Criticism and Interpretation

- Manhire, William, $1946-$

General Library of Congress subject headings:

- New Zealand - History - Fiction

- New Zealand - History - Poetry

- New Zealand fiction $-20^{\text {th }}$ century - History and Criticism

- New Zealand fiction $-21^{\text {st }}$ century - History and Criticism

- New Zealand fiction - Bibliography

- New Zealand fiction - Criticism and Interpretation

- New Zealand fiction - History and Criticism

- New Zealand fiction - Periodicals

- New Zealand poetry $-20^{\text {th }}$ century - History and Criticism

- New Zealand poetry $-21^{\text {st }}$ century - History and Criticism

- New Zealand poetry - Bibliography

- New Zealand poetry - Criticism and Interpretation 
- New Zealand poetry - History and Criticism

- New Zealand poetry - Periodicals

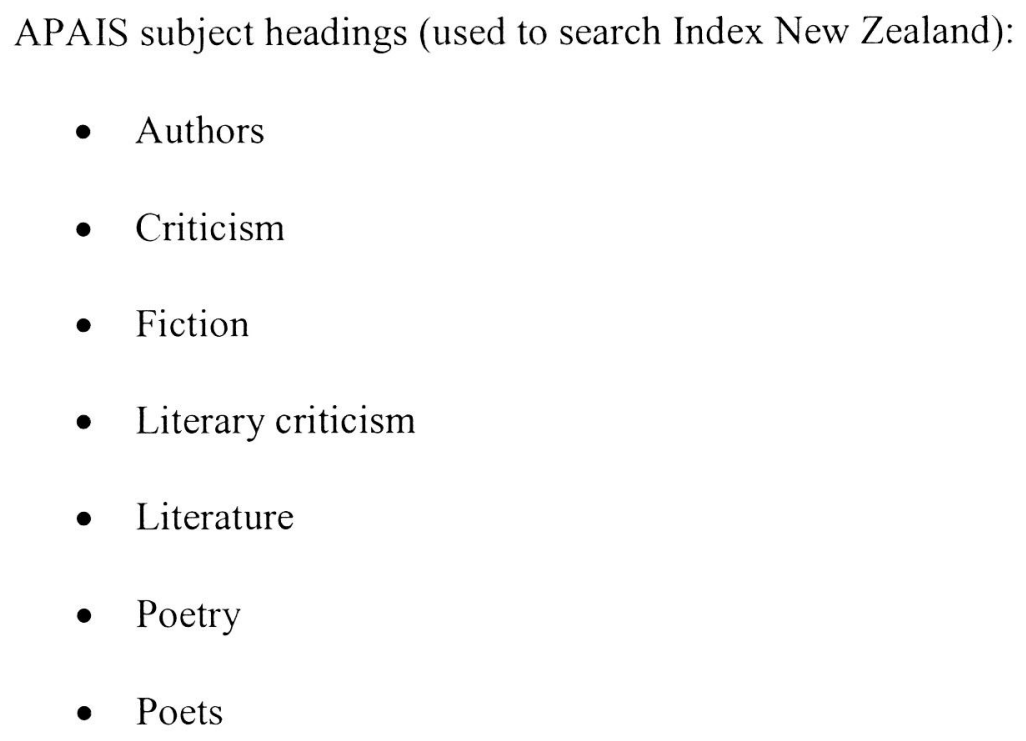

Keyword searches (used to search the Internet):

- Bill Manhire

- Commentaries

- Criticism

- Interview

- Poetry

- Reviews

- Short Stories 


\section{Presentation}

The bibliography is presented in paper format. The possibility of providing the bibliography to a wider audience through a website will be investigated at a later date.

\subsection{Arrangement}

Citations are grouped in three ways. Firstly, each collection of poetry and short stories acts as a heading. These appear in order of publication. Items that relate to each title are arranged by the author's family name or the corporate name under the appropriate heading. Where more than one item appears by the same author (or corporate name), the entries are arranged alphabetically by item title (disregarding A, An, The). Titles are included for all items, where available. Items that relate to more than one heading have a main entry under the title that is referred to most in the item content. Under the other titles that are mentioned, a 'see also' reference appears with the item number.

Secondly, items that discuss Bill Manhire's poetry and short stories in general are entered in a separate list. These works are filed by the author's last name or the corporate name. Where more than one item appears by the same author or corporate name, the entries are arranged alphabetically by title (excluding A, An, The). Items that also refer to particular poems, stories or collections of works, show a 'see also' reference under the appropriate heading. 
Finally, items written by Bill Manhire which comment on or provide insight into his poetry or short stories, are entered in a separate section. These works are filed alphabetically by title (excluding A, An, The).

This arrangement has been chosen as the most helpful to potential users of the bibliography. Subdividing by the title of Bill Manhire's work enables potential user groups to quickly identify useful references for specific pieces of poetry or short story titles (as would be needed by speech and drama students, or teachers). As the titles are listed in order of publication date, the list is also semi-chronological. A strictly chronological order of reviews and commentaries combined was considered too rigid and awkward for the ways in which a potential user might approach the bibliography, despite having some merit in tracing the evolution of thought on Bill Manhire's work. Bill Manhire's commentaries which include comment on, or insight into his own work are addressed separately. This allows the researcher to identify opinions of the work which are strictly the author's own, rather that an interpretation of his work.

Each entry has been given an individual reference number rather than a page number, to assist in creating accurate indices which are non-dependent on page numbers.

The citation style follows the Chicago A style of citations (as outlined in the Chicago Manual of Style, $14^{\text {th }}$ edition). 
Examples of citations are as follows:

\section{Monographs:}

Author surname, Author first name. Title of book. Place of publication: Publisher, Year.

\section{Chapters in Monographs:}

Author surname, Author first name. "Chapter title." In Title of book, ed. Editors name. Place of publication: Publisher, Year: Page Numbers

\section{Thesis:}

Author surname, Author first name. "Title of Thesis." Degree information, Institution completed at, Year.

\section{Periodical Articles:}

Author surname, Author first name. "Title of Article." Name of Periodical Volume, no. (Year): Page numbers.

\section{Newspaper articles:}

Author surname, Author first name. "Title of Article." Name of Newspaper (Date): Section of Newspaper, Page numbers.

Encyclopaedias and Reference books: 
Author surname, Author first name. "Name of Entry". In Name of book. Place of Publication: Publisher, Year: Page numbers.

\section{WWW Document:}

Author surname, Author first name. Name of Page. (Date Published if available). Web address [Accessed Date]

\section{Article in Electronic Journal:}

Author surname, Author first name. "Name of Page." Name of Journal Volume, Number (Date). Web address [Accessed Date]

\section{Full-text Article in Electronic Database:}

Author surname, Author first name. "Article name." Name of Journal Volume, Number (Date): Pages. Database/Article ID number

\section{Moving Images:}

Title of recording, Produced by Name, Length, Year, Video Recording.

\section{Sound recordings:}

Interviewer First Name, Interviewer Last Name. Title of recording, Produced by Name, Length, Year, Sound Recording. 
Archives:

Archives are referenced in the format of the institution from which it originates.

\subsection{Annotations}

Each citation is followed by an annotation. The annotation:

- Summarises the content;

- Names specific works mentioned;

- States where the item was obtained, if the item is rare or unique;

- Mentions the presence of illustrations, photographs, graphics etc;

- In the case of archives, notes the nature of the item (e.g. letter, journal).

The aim of the annotations is to provide descriptive rather than analytical information.

Where factual errors occur, this is also noted in the annotation.

\subsection{Appendices}

Appendices contain the following information:

- References found for items that were unable to be viewed including any information provided about the citation;

- Non-standard abbreviations used;

- The bibliography to the introduction.

- An alphabetical listing of first lines of poems, with reference to the poem title and book to which they belong.

- An alphabetical listing of poem titles and the book to which they belong. 
- An alphabetical listing of first sentences of short stories, with reference to the short story title and book to which they belong.

- An alphabetical listing of short story titles and the book to which they belong.

\subsection{Indices}

The following indices will be provided:

- Author/Personal Name;

- Subject 


\section{Malady. Dunedin: Amphedesma Press, 1970.}

1. Collier, Gordon. "Reviews." Review of Malady, by Bill Manhire. Landfall 24, no. 4 (December 1970): 418-421.

Reviews Malady, and the use of the poems in Ralph Hotere's Black Paintings I-XV from "Malady" a poem by Bill Manhire. Describes poem as "a linguistic exercise-a concrete poem by Bill Manhire based on the triad MALADY, MELODY, MY LADY".

Comments on the use of symbolism in Malady, portrayal of women, and the use of inflection. Explores the concept of extending the words into space and time and its successfulness as "an experiment in visual communication".

See also: 59, 79, 99, 115, 124, 134, 136-138, 151, 152, 156, 162.

\section{The Elaboration. Wellington: Square \& Circle, 1972.}

2. Adcock, Fleur. "Post-O'Sullivan." Review of The Elaboration, by Bill Manhire. Journal of Commonwealth Literature 9, no. 1 (August 1974): 73-74.

Describes Manhire's poetry as in a "completely opposed tradition" to that of David Mitchell (also reviewed). Briefly describes layout of publication. Mentions the use of understatement and influences. Quotes from "The Elaboration".

3. Cunningham, Kevin. "Reviews". Review of The Elaboration, by Bill Manhire. Cave 3 (February 1973): 9-10.

Briefly discusses the drawings of Ralph Hotere. Discusses the impersonality of the poems and the lack of declaration. Mentions the use of images including "darkness, light, trees, hands". Comments on the use of "I" in the poems and the "perpetual woman". Mentions the theme of love and its difficulties referring to "The Elaboration". Explores the ability of the poem to talk about life without being autobiographical and compares this to the work of Charles Spear. Discusses the use of phrasing and rhythms, comparing "The Proof" and "A Death in the Family" to "Pavilion" and "The Prayer". Briefly discusses line-endings.

\section{Gager, Owen. "Reviews". Review of The Elaboration, by Bill Manhire. Salient 35, no. 11 (31 May 1972): 13.}

Discusses the title in relation to the poems. Critiques the idea of the "metaphysical distinction between truth and fiction, art and reality". Briefly discusses "A Hope for Frank and Anne" and the 'poetic' vocabulary. Mentions the surrealist quality of the work referring to "The Spell". Briefly mentions Glover, Auden, and Dylan Thomas in relation to the poems. 


\section{Graculus. "Reviews". Review of The Elaboration, by Bill Manhire. Critic (27} June 1972): 13.

Briefly mentions the appearance and composition of the volume including the contribution of Ralph Hotere and noting "A Death in the Family" and "The White Pebble". Discusses the idea of arbitrariness and that the poems may "gain...only that form given them by the reader". Discusses and quotes "Your Absence" and the 'Elaboration' technique.

6. Long, D. S. "Literary Notes". Review of The Elaboration, by Bill Manhire. Arts \& Community 8, no. 9 (September 1972): 9.

Compares Manhire to Ted Hughes' "Crow" and John Haines. Briefly discusses Hotere's drawings. Mentions the recurring images including the moon and water. Explores the idea that "a poet's skill lies in the manner in which a poem might lead us to our own discoveries, suppositions, identifications, reinforcements" giving "Pavilion" as an example.

\section{Roddick, Alan. "Fictions in Miniature". Review of The Elaboration, by Bill Manhire. Islands 1, no. 1 (Spring 1972): 73-74.}

Describes Manhire's use of characters and truth, quoting "A Hope for Frank and Anne", and noting the obvious influence of American poetry. Discusses "The Elaboration", quoting the poem, and the movement and lines. Mentions Hotere's drawings and their relationship to the poems, quoting "Pavilion".

See also: 25, 59, 86, 92, 93, 99-101, 133, 134, 138, 151, 152, 166, 168

\section{Song Cycle. Performed 1975.}

8. Body, Jack, 1944- : Papers (MS-Group-0141). "Song Cycle ; [for 2 dancers, 2 musicians, tape]”. Alexander Turnbull Library, f-80-264-53.

Item number two (typed A4 page, author not identified), describes the way the poems were used, particularly the "disassembling the poems into single words and phrases". Notes the non-recording of two of the original seven poems, and mentions the poetic differences in these to the others. Comments on the usage of the poems throughout the piece, including repetition, noting "The Seasons". Discusses the "liberties" taken with the poems, mentioning boundaries, spaces and sound. Notes the voices on the recordings as Manhire and Kris Klocek. 
Other contents include annotated (circling and/or noting of key words, underlining) copies of Manhire's poems including "The Wind (I)", "The Wind (II)", "The Voyage", "Love Poem", "Vidyapati's Song", and "Wulf".

See also: $124,136-138,162$

\section{Dawn/Water. Eastbourne: Hawk Press, 1979.}

9. Green, Tony. “An Artist's Edition". Review of Dawn/Water, text by Bill Manhire, images by Andrew Drummond. Art New Zealand 17 (1980): 70-71.

Provides a physical description of the volume and the layout of the text on the page.

Discusses the contribution of the text to the prints and vice versa.

10. Robinson, Roger. "A Poem and a Housefly". Review of Dawn/Water, text by Bill Manhire, images by Andrew Drummond. Listener 95, no. 2111 (28 June 1980): 73 .

Briefly discusses the layout of the book. Comments on use of words, the enigmatic quality of the poem, and the use of irony.

See also: 115, 124, 136, 156, 162

\section{How to Take Off Your Clothes at the Picnic. Wellington: Wai-te-ata Press, 1977.}

11. Arvidson, K. O. "Comprehending Death". Review of How to Take Off Your Clothes at the Picnic, by Bill Manhire. Listener 90, no. 2033 (16 December 1978): 69.

Discusses the disconcerting qualities of the work including the ease of response and the difficulty of describing the poetry. Mentions the use of love lyrics to comment on the nature of reality. Interprets Manhire's stylistic preoccupation as "the constant and random shifting of man's focus of perception and comprehension". Quotes from "The Song". Discusses the use of the symbolist technique, and the childlike quality of the poetry through the use of imagery, mentioning "The Kiss". Comments on the use of tonal shifts. 
12. Edmond, Lauris. "Reviews". Review of How to Take Off Your Clothes at the Picnic, by Bill Manhire. Landfall 33, no. 1 (March 1979): 72-77.

Questions the value of style and grace as opposed to "force and simplicity". Discusses the use of changing imagery and the subversion of the readers expectations. Talks about the relationship between the titles and the poems themselves, noting "The Incision" and "Turtle". Examines Manhire's ability to give new meanings to "well-worn phrases", creating humour, or metaphors for behaviour. Describes poems as a sort of conversation, quoting "Summer". Briefly discusses "The Snow". Comments on the use of phrasing, ideas and verbal games in "The Mutability Cantos" and "Devotion". Posits the idea of "figures of speech" as the basis for some of the compositions. Concludes Manhire's poems are dissimilar to those of Yeats, Rilke, Walt Whitman and Baxter.

13. Simpson, Peter. "Dangerous Beautiful Dislocations". Review of How to Take Off Your Clothes at the Picnic, by Bill Manhire. Comment, n.s., 4 (August 1978): 34-36.

Discusses the relationship between the poet and the reader in "Contemplation of the Heavens". Posits that Manhire's poetry "repel[s] all possibility of "understanding"”. Discusses the use of distortions, "verbal nonsense", absurdity, fantasy and wit. Briefly draws a comparison with Creeley. Examines the internal logic of the poems and the "apparently total indifference to the reader's presence or comprehension". Briefly mentions "The Importance of Personal Relationships" and "The Paperweight". Concludes that if Manhire has an antecedent, it would be Charles Spear. Comments that only two poems identify the book as New Zealand in origin: "The Collection", and "How to Take Off Your Clothes at the Picnic".

See also: 25, 59, 93, 100, 101, 119, 133, 134, 152, 166, 168

Zoetropes. London: The Murihiku Press, 1981.

See: 168

\section{Good Looks. Auckland: Auckland University Press, 1982.}

14. Alley, Elizabeth. "Readings, and an Interview with Bill Manhire". Produced by Stout Research Centre, 6 min., 1982, Sound Recording.

Reads "Good Looks" and "When You're Dead You Go on Television". Discusses the naming of the collection, including the passing of time, and that if you are going to write "part of your function, presumably, is to look hard at what's around you". Examines the title, the role of words, and "how language handles reality". Comments on the origins of 
"When You're Dead You Go on Television", and the serendipity in language. Discusses Manhire's year in London, and his reading of British poetry.

15. Bland, Peter. "Still Water." Review of Good Looks, by Bill Manhire. London Magazine 22, no. 11 (February 1983): 79-81.

Discusses Manhire's “insights” and taking nothing for granted. Briefly mentions the technique of using a closed rhyme in free verse. Examines the number of styles and 'voices' in the collection.

16. Davis, Leigh. "Preferences II: a Programme about Choice in N.Z. Poetry". Produced by Stout Research Centre, 10 min., 1986, Sound Recording.

Reads "Good Looks". Discusses its abstract nature. Identifies five elements which make it abstract. Comments on the use of monosyllables, to create a jumpy effect, which creates confusion. Mentions the use of rhetorical questions which suggest that the reader should know the answer. Discusses the use of impersonal and philosophical subjects, repetition, the use of "we", and making "an abstract quality seem active". Examines how the poem builds an argument on abstract nouns, and the lack of context for these.

Comments on the momentum of time, including tone, and the use of the English Christian Tradition. Concludes that the poem "writes against its own appearance of a simple story".

17. Garrett, Simon. "Departures". Review of Good Looks, by Bill Manhire. CRNLE Reviews Journal 1 (July 1983): 12-14.

Mentions themes including "the physics of the universe, society, his family, friends, lovers". Discusses "The Breakfast Session" and the relationship between writing and life. Identifies the theme of the book as superficiality and "a study in the growth of a poet's mind". Discusses "The Buried Soap" and "A Song about the Moon" commenting on the use of tension. Briefly examines the use of "you" in the poems. Discusses "An Outline" and the connection between the last and first poems of the collection.

18. Johnson, Louis. "Fingertip Control”. Review of Good Looks, by Bill Manhire. Listener 101, no. 2221 (21 August 1982): 85-86.

Discusses the innovative quality of Manhire's poems without "transgressing the borders of literacy". Explores "The Swallow" and traps for the reader. Comments on what the poem is 'about', and the adequacy of this approach for the reader. Describes Manhire's "Modernism" as surrealist which goes into a "mystery-shrouded past", and explores the possibilities of the language. 
Includes head photograph of Manhire.

19. Pybus, Rodney. "American and Australasian Poetry". Review of Good Looks, by Bill Manhire. Stand Magazine 25 no. 3 (Summer 1984): 56-62.

Discusses the range of "modes", noting the "avoidance of narrative or discursive conventions", and the use and effects of imagery. Mentions the elusive nature of the poems, noting common images. Quotes "An Outline" as being symbolic of Manhire's attitude to poetry. Notes the satire of "Wellington" and the versions of Old English poems.

20. Rhodes, H. Winston. "Blurbs and Occasions". Review of Good Looks, by Bill Manhire. New Zealand Monthly Review 23, no. 247 (September 1982): 16-17.

Discusses at length the blurb from the book, including the references to "Wellington" and "Children". Explores the idea that the book has a "recurring theme that might be inadequately described as the human predicament" noting "You: A Fragment". Comments on themes including death, life, the past, future and present. Briefly discusses Manhire's use of words.

See also: 24, 25, 63, 92, 93, 98, 99, 100, 110, 119, 133, 134, 151, 166, 168

\section{Zoetropes: Poems 1972-1982. Sydney: George Allen \& Unwin Australia Pty Ltd, 1984.}

\section{Alley, Elizabeth. "An Interview with Bill Manhire”. Produced by Stout Research Centre, 14 min., 1985, Sound Recording.}

Discusses the word "zoetrope", its origins, and relationship to the poem "Zoetropes". Mentions the cover illustration and it's relationship to the collection. Comments on Manhire's sense of narrative, and the processes in life when looking through the book. Examines objectivity and observes that the "person who wrote the earlier poems isn't me, but something that I was". Discusses the difference between the person who makes the poems, and the presence in the poems, including invention and creation. Defines "the poem as an act of discovery, rather than the poem as a process of recording something you knew already". Discusses language in New Zealand poetry, and its use as a means of exploration. Mentions the poems at the end of the book, and the sense of distance between self and home, middle age and childhood. Comments on how the performance of poetry impacts on his writing, referring to rhythm and line endings on the page. Discusses his next projects including plans to write short stories. 
22. Gracewood, Jolisa. "Zoetropes by Bill Manhire".

http://www.arts.uwo.ca/ andrewf/articles/manhire.htm [accessed 19/06/02].

Interpretation of "Zoetropes" from the soc.culture.new-zealand newsgroup. Discusses Manhire's use of conceits. Makes a connection between "Zoetropes" and Sylvia Plath's "Balloons". Examines the use of the letter $\mathrm{Z}$ as a formula representing distance, New Zealand, the eye's movement when reading, and the pronunciation of the letter. Briefly discusses "Water, A Stopping Place".

23. Pybus, Rodney. "Recent Poetry". Review of Zoetropes: Poems 1972-1982, by Bill Manhire. Stand Magazine 28, no. 1 (Winter 1986/87): 69-78.

Mentions Manhire's eye for oddity, quoting "Breakfast". Notes the use of breaks between line, stanza and cadence, and parenthesis. Briefly discusses "The Afterlife" and the use of a cliché at the end of the poem. Notes the differences between the new poems compared to his earlier work in sentence and stanza structure. Quotes "A Scottish Bride" and it's use of "wry coolness".

24. Sharp, Iain and Peter Alcock. "Two Responses". Review of Zoetropes: Poems 1972-1982 by Bill Manhire. Landfall 39, no. 2 (June 1985): 237-244.

Sharp discusses the contents of the book, including its compilation from other works, notable omissions, and the contents which fall outside the stated dates. Lists authors with whom Manhire has some commonalities (Creeley, Bly, Roethke, Ignatow) and two actors - Buster Keaton and Bruno S. States Manhire is a pessimist who "tempers the gloom, however, with a warmth of human sympathy". Describes Manhire as a "private voice" with an emphasis on truthfulness as opposed to truisms. Characterises Manhire as a "domestic poet", mentioning "The Distance Between Bodies" and "Love Poem". Comments on the use of clichés, mentioning "The Pickpocket", and the use of "hesitations, hiccoughs, and vague little throwaway phrases" (noting "The Mutability Cantos"). Discusses the subject of life and the uncharacteristic weariness throughout Good Looks and "The Afterlife".

Alcock discusses "Contemplation of the Heavens (after Camille Flammarion)". Comments on the irony in "The Buried Soap" as an excoriation of Matthew Arnolds "The Buried Life". Briefly mentions "The Cinema". Describes Manhire as having "an acute

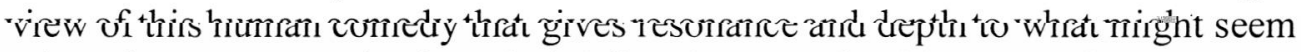
otherwise... communication of trivia". Discusses the title poems from The Elaboration and How to Take Off Your Clothes at the Picnic. Briefly examines "The Importance of Personal Relationships", "The Song", "Last Sonnet", "The Buried Soap", "Wellington" and "Good Looks". Also notes "The Anglo-Saxon Onion", "Wulf", "When You're Dead You Go on Television" (as a "throwaway family poem"), and "Declining the Naked Horse" (as an "ingenious joke"). Briefly discusses longer poems and the use of 6-8 line 
stanzas including "The Selenologist", "The Afterlife", "An Outline", and "The Voyeur: An Imitation".

25. Simpson, Peter. "Three Syllables above Two Wheels". Review of Zoetropes: Poems 1972-1982, by Bill Manhire. Listener 109, no. 2350 (2 March 1985): 32.

Discusses "Zoetropes" and the use of the word as a signifier. Posits that the word is a "metaphor (trope?) for Manhire's conception of poetry; at once a mechanical toy and the "wheel of life"" Comments on the national reference, the break this represents from previous poems, and compares it to poems by Brasch, Curnow and Wedde. Discusses the idea of poems made out of "found words" mentioning The Elaboration, How to Take Off Your Clothes at the Picnic, Good Looks, and quoting from "The Prayer", "Summer" and "The Afterlife". Comments that the new poems are more sequential and orthodox, quoting "Legacies". Examines the idea of originality, referring to "On Originality" and the relationship between a poet's work and the wider poetic tradition.

Includes head and shoulders photograph of Manhire.

See also: 93, 110, 157, 166, 168

\section{The Brain of Katherine Mansfield. Auckland: Auckland University Press, 1988.}

26. French, Blair. "Books". Review of The Brain of Katherine Mansfield, by Bill Manhire. Critic (4 April 1989): 11.

Discusses the use of the South Island as a setting unfamiliar land to most New Zealanders. Mentions the use of pop culture and myth. Examines his "desire to communicate in a tense relationship with deferral of meaning in the language". Explores the idea of the readers' decision making process and the predetermined outcomes created by the author.

27. Schofield, Dennis. "Beyond The Brain of Katherine Mansfield: The Radical Potentials and Recuperations of Second-Person Narrative". Style (University of Arkansas) 31, no. 1 (Spring 1997): 96-118.

Discusses the readers familiarity with the genre, including the typical second-person narrative. Comments on the readers role in as deciding the outcome through the "roleplay illusion". Explores the use of "you" and the "you" to which anyone can relate, which moves to a "more fully narrativized "you"". Notes that Manhire's "you" remains generalised. Provides a full discussion on the use of the second-person narrative from a variety of authors including Michel Butor, Daniel Gunn and Georges Perec. Posits that 
the first paragraph of The Brain of Katherine Mansfield is in fact "a disguised "I"".

Briefly discusses signifiers and proper nouns.

Includes diagrams illustrating the relationship between the world, reader, text, story, narrator, character and "you".

28. Sharp, Iain. "Reviews". Review of The Brain of Katherine Mansfield, by Bill Manhire. Landfall 42, no. 3 (September 1988): 327-330.

Discusses the title. Mentions the idea of mockery in the book. Examines the use of the "twist-a-plot" genre, its conventions, and the opening of the book. Comments on the use of Gregory O'Brien's illustrations. Briefly discusses "Magasin" and "Allen Curnow meets Judge Dredd", the use of high and low registers, and how these are used in the book. Examines use of language which mimics "New Zealand travel brochures", and those of other New Zealand writers. Mentions the notion of freewill, and the illusion of options. Discusses the ability of the author to bully the reader in the genre.

See Also: 56-58, 60, 62, 65-71, 114, 129, 132, 159, 166

\section{The New Land: A Picture Book. Auckland: Heinemann Reid, 1990.}

29. Atwool, Margaret. "Fiction". Review of The New Land: A Picture Book, by Bill Manhire. Infochoice, no. 5 (July 1990): 2.

Mentions the variety of contexts in which the stories take place, both geographically and historically. Describes the range of tones, mentioning "Highlights" and "Sienna". Briefly mentions the use of allusions.

30. Barrowman, Fergus. "Introduction". In The Picador Book of Contemporary New Zealand Fiction, ed. Fergus Barrowman. London: Picador, 1996: vii-xli.

Mentions Manhire as "the name critics reach for first when referring to post-modern tendencies in recent fiction". Discusses "Ponies" and the context of Gandhi's assassination. Comments on the use of realism, and the role of the narrator. Notes connections to the Antarctic and the anti-nuclear policy.

31. Byrt, Neville. "Collage of Colonial Tenses". Review of The New Land: A Picture Book, by Bill Manhire. New Zealand Herald (24 March 1990): 6.

Discusses techniques which enable the stories to move across time. Examines the theme of obsessions that "might be loosely defined as the national character". Mentions the range of subjects in the stories. Comments on the use of language and imagery 
particularly in "Highlights" and "The New Land". Discusses Manhire's humour noting "Some Questions I Am Frequently Asked".

32. Causley, Charles. "Reviews". Review of The New Land: A Picture Book, by Bill Manhire. Landfall 44, no. 4 (December 1990): 510-512.

Discusses Manhire's voice, including spareness in the language and the allusive quality of the text. Mentions the use of "disturbing images and intimations [which] operate just beneath the calm surface of the narrative". Explains the result as juxtaposing fiction and reality. Posits that Manhire's stories ask questions of himself and fellow New Zealanders ("Where do you come from? Why are you here?"). Summarises the stories as breaking stereotypes and received ideas.

33. Eggleton, David. "Assemblages of Entertainment". Review of The New Land: A Picture Book, by Bill Manhire. Otago Daily Times (21 July 1990): 21.

Discusses the "idea of things as national emblems" and Manhire's use of the first-person male narrator. Examines the use of the stories to illustrate the difference between what a thing is and how it is perceived through language, in particular the use of clichés and platitudes. Mentions the use of information snippets. Comments on "Highlights", "Days of Sail", "South Pacific", "Some Questions I Am Frequently Asked" and "Cannibals". Describes Manhire's style as "Zen-like and Japanese".

\section{Jones, Lawrence. "Disquieting Pictures of a New Land". Review of The New Land: A Picture Book, by Bill Manhire. Evening Post (24 March 1990): 31.}

Compares Manhire's poetry and prose styles. Discusses his ability to write in the vein of New Zealand realism, noting "South Pacific", "Highlights", and "Ponies". Examines metafictional fantasy in "Some Questions I Am Frequently Asked" and "Cannibals". Summarises "The Days of Sail". Briefly mentions parody in "Cannibals" and "Nonchalance or The New Land: A Picture Book". Comments on Manhire's "satiric element, aimed at the media simulacrum-touristy-post-modern surfaces world of contemporary New Zealand". Discusses his use of time and place in New Zealand.

35. Kaganoff, Penny. "The New Land: A Picture Book". Review of The New Land: A Picture Book, by Bill Manhire. Publishers Weekly 237, no. 20 (18 May 1990): 77.

Discusses the presence of wit and "contemporary middle-class experience" in the stories. Mentions "Some Questions I Am Frequently Asked", academia, and it's "tongue-incheek" approach. Briefly mentions the use of cynicism, and imagery, noting "The Days of Sail". Discusses "South Pacific" and human relationships. 
36. King, Michael. "Books: Closing the Gap". Review of The New Land: A
Picture Book, by Bill Manhire. Metro, no. 108 (June 1990): 146, 148.

Discusses the surreal and "manic" quality of the stories, and posits its antecedents as The Goon Show and Monty Python. Briefly mentions the use of time in the stories. Examines the negative effect of eccentricity in "Some Questions I Am Frequently Asked".

\section{Knox, Elizabeth. "The World as We Know It". Review of The New Land: A Picture Book, by Bill Manhire. Dominion (10 March 1990): 7.}

Describes the book as about "nationhood". Discusses the use of the index as a form of narrative. Explains the significance of the cover by Colin Edgerley. Mentions the use of contrasts in "Highlights". Examines "Some Questions I Am Frequently Asked" and the New Zealand literary stage. Briefly mentions "South Pacific". Describes Manhire's fiction as "satirical, but often compassionately so, funny, amusing while producing unease, and indefinably sad".

Includes head photograph of Manhire.

38. Lay, Graeme. "A Hall of Distorting Mirrors". Review of The New Land: A
Picture Book, by Bill Manhire. Dominion Sunday Times (18 March 1990): 15.

Discusses the use of time, space and culture. Summarises "Highlights". Examines the use of time and place in "Ponies". Mentions narrative and chronology in "Cannibals". Comments on the idea of ourselves in "Some Questions I Am Frequently Asked" and "Nonchalance". Describes the use of the index as "a bit too cute for words". Concludes that the book reflects ourselves and our heritage.

39. "Manhire, Bill The New Land". Review of The New Land: A Picture Book, by Bill Manhire. Books to Buy, no. 113 (13 May 1990): 20.

Mentions the use of humour, stating that the book will "appeal to some and elude others". Notes the storylines of "Ventriloquial" and "Cannibals". Briefly mentions the use of satire and the New Zealand context. Suggests that some people "would find it all tiresome and self indulgent". 
40. Neale, Emma. "Arts". Review of The New Land: A Picture Book, by Bill Manhire. Salient 53, no. 7 (20 April 1990): 9.

Discusses the setting up of expectations by the front cover, and the undercutting of definitions. Mentions the range of humour, and the mixture of humour and sadness, noting "South Pacific". Examines the presence of New Zealand in the stories, including the index. Mentions the movement of character between "Ventriloquial", "The Days of Sail", and the character in the index.

41. Sharrad, Paul. "New Zealand". Review of The New Land: A Picture Book, by Bill Manhire. World Literature Today 65, no. 1 (Winter 1991): 191-192.

Mentions Manhire's allusions to other writers and the index of "issues and figures". Comment on tone and comic elements. Mentions "Highlights", "Ponies", "Siena", and their comment on New Zealand in the world. Briefly examines "South Pacific", and the use of cliché in "Cannibals".

42. Standring, Douglas. "Strange Truths". Review of The New Land: A Picture Book, by Bill Manhire. Listener 127, no. 2622 (11 June 1990): 110.

Discusses the theme. Explores the idea of history and colonialism against tourism in "Highlights". Examines Manhire's concern with representation and the use of wit and parody against the national identity. Comments on "Days of Sail" and the use of time and fragments of the past. Briefly mentions "Siena", "Nonchalance, or The New Land: A Picture Book", and "Some Questions I Am Frequently Asked" and its use of the interview format. Examines "Ventriloquial" and the use of satire. Explores Parody referring to "Cannibals" and the use of past and present. Mentions Manhire's use of language, representation and juxtaposition in the index.

Includes full-length sitting photograph of Manhire.

\section{Wevers, Lydia. "The Short Story". In The Oxford History of New Zealand Literature in English, ed. Terry Sturm. Auckland: Oxford University Press, 1998: 245-320.}

Briefly discusses the collection, and its resistance to "textual classification" noting the index. Mentions the use of "texts" in order to 'know' New Zealand culture naming Janet Frame in "South Pacific" and adventure stories in "Cannibals". Posits that his fiction represents a move to post-colonial from the post-modern.

See also: 59, 70, 98, 129, 138, 148, 149, 151, 157, 163, 166 
The Old Man's Example. Wellington: Wrist \& Anchor Press, 1990.

See also: 134, 138, 166, 168

Milky Way Bar. Wellington: Victoria University Press, 1991.

44. Allan, Guy. "Of Wondrously Delicate Powers." Review of Milky Way Bar, by Bill Manhire. New Zealand Herald (15 June 1991): 6.

Discusses the effect created by not using obvious conceits, and making "no big deal even when the deal looks very big". Explores the idea of the reader and/or writer making a "mistake" and the ambiguity this creates. Briefly mentions "Allen Curnow meets Judge Dredd", "My Lost Youth", "Synopsis", and "Hirohito".

45. Ensing, Riemke. "The Shape and Stuff of Time". Review of Milky Way Bar, by Bill Manhire. Listener 130, no. 2675 (1 July 1991): 50-52.

Discusses the 'Out West' image. Briefly discusses "Milky Way Bar", "Out West", and "Phar Lap". Mentions Manhire's use of language as "quirky, clever, [and] full of wit".

46. Faith, Rangi. "Manhire's Humour". Review of Milky Way Bar, by Bill Manhire. Press (Christchurch) (24 August 1991): 27.

Briefly mentions the use of humour, noting "Out West" and "Magasin". Discusses the meaning of "Jalopy: The End of Love", "Factory" and "Milton".

47. Gadd, Bernard. "New Zealand". Review of Milky Way Bar, by Bill Manhire. World Literature Today 66, no. 4 (1992): 785.

Discusses Manhire's collection as broadly postmodern, notes the use of "scenes within scenes", and the place of the reader. Mentions the explanatory notes with "Synopsis (Handel's Imeneo)" and "Life with Madame Rosa" in order to help the reader.

Comments of the use of surprises and puzzles. Mentions the use of "everyday language", and the relationship between the author and the reader. Discusses the use of history, noting "Our Father", "Early Days in the Colony" and "Hirohito". Examines his use of geography, mentioning the South Island, Brazil and the Milky Way. Comments on "Allen Curnow Meets Judge Dredd" and the use of the "postmodernist idiom". Mentions the recording of poetry, and the "social and cultural conditions" that exist, noting "Agitated Nation" and "Princess: The Treatment". 
48. Greet, Annie. "Yours with Love, Bill \& Co." Review of Milky Way Bar, by Bill Manhire. CRNLE Reviews Journal, no. 1 (1993): 70-76.

Discusses Manhire's technique of recording "the tics, impulses and one-liners" of life, noting "Milky Way Bar" and "Synopsis (Handel's Imeneo)". Explores humour in Manhire's poetry, in relation to "Magasin". Touches on his use of characters and history ("Hirohito", "Phar Lap", and "Hurricane") and notes a similarity to Dinah Hawken. Discusses the amount of detail offered readers, noting "Allen Curnow Meets Judge Dredd" and "Out West". Posits the idea that the collection is written for a New Zealand audience. Briefly mentions "Brazil" and imagery.

49. Kennedy, David. "The Ongoing Past". Review of Milky Way Bar, by Bill Manhire. TLS: The Times Literary Supplement, no. 4636 (7 February 1992): 19.

Notes the influence of Baxter and Curnow. Likens Manhire to Lee Harwood in the use of narrative which is subverted through humour and colloquialisms, mentioning "Out West" and "Phar Lap". Discusses the sections of the book and their themes - memory (mentioning "Magasin"), politics (mentioning "Agitated Nation"), satire, and recent history. Discusses the lack of "tonal variation" and withdrawal, mentioning "Milky Way Bar".

50. Reeve, Simon. "Print". Review of Milky Way Bar, by Bill Manhire. Stamp, no. 34 (September 1992): 45.

Briefly discusses "Alan [sic] Curnow Meets Judge Dredd”. Examines Manhire's concerns with language and place noting "Milky Way Bar". Mentions the "cultural complexities, the diverse identifications" in "Brazil". Also discusses "Early Days in the Colony", and quotes "Breaking the Habit".

51. Riach, Alan. "Poetry to Charm but also Unsettle". Review of Milky Way Bar, by Bill Manhire. Dominion Sunday Times (5 May 1991): 22.

Describes Manhire's poetry as "laconic and polite, surprising and unsettling”. Briefly mentions "Hirohito", "Brazil" and "Phar Lap". Discusses the fourth section of the book and its attempt at "a more sustained approach to the phenomena which concern him", including the ideas of language, isolation and community. Examines his use of humour. 
52. Sewell, Bill. "Spareness and Generosity". Review of Milky Way Bar, by Bill Manhire. New Zealand Books 2, no. 2 (September 1992): 15.

Review of Milky Way Bar and Short Back \& Sideways by Hone Tuwhare, comparing and contrasting the two. Discusses the quality of spareness, both with words and line length, for example "Masturbating". Briefly examines two statements from "Magasin" and "Milky Way Bar", and the idea of the "anti-poem". Comments on the subject matter of "A Winter Christmas", "Hirohito" and "Brazil".

53. Turner, Brian. "Lonie's Unjust Exclusion from the Anthologies". Review of Milky Way Bar, by Bill Manhire. Otago Daily Times (29 June 1991): 21.

Comments on Manhire's attitude to events and contrasts this to Lonie. Discusses the qualities of his poems on childhood, family, youth and family relationships. Mentions "Brazil" and "Milky Way Bar" and the idea of journeys. Examines the use of humour in "Brazil" and briefly in "Out West". Comment on the reviewers reservations about the earlier poems as too 'oblique'. Touches on the title and its relationship to the poems.

54. Wall, Julia. "Arts and All”. Review of Milky Way Bar, by Bill Manhire. Salient 54, no. 9 (6 May 1991): 13.

Quotes from "Breaking the Habit" and comments on the conversational quality. Discusses the use of images referring to "South Island Companion". Mentions the use of language including the word "jalopy".

55. Whiteford, Peter. "Giving Words a Playful Nudge". Review of Milky Way Bar, by Bill Manhire. Evening Post (5 April 1991): 9.

Discusses the use of language and the commonplace, noting "Out West" and "Phar Lap". Comments on the use of puns and clichés. Mentions possible influences on Manhire including Joyce in "Magasin", Williams in "My Lost Youth", and Manhire's distinctive voice. Examines the ways in which the poetry engages the reader, including its seeming simplicity, literacy and intelligence. Discusses his use of words and pauses to create ambivalence. Mentions the subjects of poems and the "conviction that there are no "appropriate" subjects for poetry".

See also: 59, 92, 96, 99, 108, 149, 151, 157, 159, 166, 168

\section{An Amazing Week in New Zealand. Wellington: Just As I Am Press,} 1993.

See: 61,63 


\section{South Pacific. Manchester: Carcanet Press Limited, 1994.}

56. Jones, Dorothy. "New Zealand”. Review of South Pacific, by Bill Manhire. World Literature Today 69 no. 2 (Spring 1995): 441.

Discusses the use of narrative, including fragments and their arrangement into stories. Mentions "The Brain of Katherine Mansfield" and the way the narrative ends with "Close the book". Examines the use of games with the reader, noting "South Pacific" and "Cannibals", and the "send[ing] up [of] classics". Mentions "Wings of Gold", and the ability to tell fact from fiction. Discusses "The Days of Sail" and "Highlights", and the images of New Zealand.

57. McFall, Gardner. "In Short - Fiction”. Review of South Pacific, by Bill Manhire. New York Times Book Review (3 April 1994): 16.

Briefly mentions "The Brain of Katherine Mansfield" and metafiction, and "Wings of Gold". Comments on satire and parody in the collection noting "Cannibals" and "Some Questions I Am Frequently Asked". Identifies "Highlights" and "Flights of Angels" as more traditional fiction concerning family relationships.

58. Smith, Vanessa. "A Poet Stirs Abroad". Review of South Pacific, by Bill Manhire. TLS: The Times Literary Supplement, no. 4744 (4 March 1994): 20.

Mentions the use of narrative voices and genre parody. Briefly mentions "The Brain of Katherine Mansfield" and "Some Questions I am Frequently Asked". Comments on the understatement of "The Poet's Wife". Discusses the recurrent use of the tourist mentioning "Highlights" and the consumer culture, and "Siena". Briefly mentions "The Moon at the End of the Century". Examines Manhire's view of colonial history noting "Cannibals", "The Days of Sail", "Nonchalance, or The New Land: A Picture Book", and "South Pacific".

See also: 70, 129, 159, 166

\section{Sheet Music: Poems 1967-1982. Wellington: Victoria University Press 1996.}

59. Beard, Tom. "You Cannot Forget It". Review of Sheet Music: Poems 19671982 and My Sunshine, by Bill Manhire. New Zealand Books 6, no. 2 (June 1996): 11-12.

Discusses the iconography of song in relation to Manhire's poetry, particularly in $M y$ Sunshine. Describes lyricism in relation to the vocabulary used, and the image of water in this lyricism (which is compared to Greg O'Brien and Dinah Hawken). Examines the 
image of snow (How to Take Off Your Clothes at the Picnic, My Sunshine, "Hoosh", "Some Screens", "Doctor Zhivago"), and its use as a "covering". Discusses the ambiguous use of language "where one is never sure whether the words refer to themselves or to physical and emotional realities", and poems that are about words, noting Malady, "The Asterisk Machine", Milky Way Bar, "Magasin", "Jalopy", My Sunshine, and "Isabella Notes". Identifies Manhire's use of awkwardness of tone noting "The Importance of Personal Relationships" to establish character, satirise and create irony.

Discusses the influence of Robert Creeley and William Carlos Williams on Manhire's poetry mentioning "La Noche", "The Importance of Personal Relationships", and "The Proposition". Compares style to Eliot and Craig Raine. Briefly mentions the repeated imagery of wrists and throats throughout his work. Comments on the Manhire School, and their influence on the perception of Manhire himself, noting Milky Way Bar, "The English Teacher", "In the Studio", in comparison to The Elaboration and How to Take Off Your Clothes at the Picnic. Notes the increasing use of the narrative after writing The New Land, in Milky Way Bar and My Sunshine, particularly "Your Room", "The English Teacher", "In the Studio", "Hoosh", and "An Amazing Week in New Zealand". Discusses the exploration of "I" and "you", and "I" and "it" mentioning "Milky Way Bar". Explores Manhire's attempt to "map the universe", its relationship with cartography in "The Calendar" and "The Afterlife", and Christianity in "An Amazing Week in New Zealand" and "The Prayer".

60. Eggleton, David. "The Ultimate Riddler". Review of Sheet Music: Poems 1967-1982, My Sunshine, and Songs of My Life, by Bill Manhire. Listener 153, no. 2922 (27 April 1996): 42-43.

Explains "Wingatui" and its appearance in "Pseud's Corner". Discusses "The Elaboration" and "The White Pebble". Identifies recurring words used in various combinations including forest, moon, time, page, light. Mentions Manhire's use of "pop song tunes, popular sayings, half-remembered facts". Discusses his use of compression, silence and subversion. Describes the difficulty of applying a literal translation to poems in My Sunshine. Examines the influence of his South Island origins in the poems. Talks about the general nature of the characters in Songs of My Life. Briefly mentions "The Brain of Katherine Mansfield", "The Poet's Wife" and "Wings of Gold: A Week Among Poets".

Includes caricature of Manhire.

61. Gilling, Ana. "Books". Review of Sheet Music: Poems 1967-1982 and My Sunshine, by Bill Manhire. Salient 59 no. 6 (25 March 1996): 42.

Mentions the longer poems of My Sunshine including "Hoosh" and "Moonlight". Comments on Manhire's "generation and heritage" in relation to "An Amazing Week in 
New Zealand" and "Remarkables". Briefly mentions Sheet Music, in particular "On Originality" and "Declining the Naked Horse"

62. Riach, Alan. "Reviews". Review of Sheet Music: Poems 1967-1982, My Sunshine and Songs of My Life, by Bill Manhire. Landfall n.s., 4, no. 2 (Spring 1996): 330-336.

Discusses the use of "Medieval English lyrics, riddles and rat-rhymes", order and ego. Explores "Wings of Gold: A Week Among Poets", mentioning academic humour, farce, politics (quotes from the story), and internationalism. Comments on seriousness, referring to "The Brain of Katherine Mansfield" and childishness. Discusses the use of humour in "Some Questions I Am Frequently Asked". Compares "Cannibals" and Brasch's "The Islands".

Explores "Wingatui", mentioning it's publication in "Pseud's Corner", and the puzzle of the last two lines. Quotes James Graham's "Marquis of Montrose" and the way "Wingatui" recollects it. Discusses the metaphorical and abstract in "Wingatui", specifically the "azure violin". Mentions "Love Poem" and the use of 'almost'. Briefly discusses the cover of My Sunshine. Contrasts Manhire to Curnow and Baxter. Discusses the cover of Sheet Music and the connection between the cover and the poems. Quotes from "Banal Sojourn" and "A Primitive like an Orb" by Wallace Stevens and compares his weaknesses to Manhire's, namely the lack of "the recognition of the nearness of tragedy, and the possible presence of maniac energy", and the use instead of shyness and hesitation.

Quotes "The River", and mentions "How to Take Off Your Clothes at the Picnic" and a number of unnamed poems, mentioning the absurd, delivery, surrealism, mutability, fear and childish things. Discusses "ancestral history" mentioning "A Scottish Bride", "Ain Folks" and the use of humour, irony and pathos. Mentions the hesitancy of My Sunshine, quoting "Blade \& Swing". Comments on a number of the 'storylines' of the poems in My Sunshine. Briefly mentions "Doctor Zhivago", "Moonlight" and "On Originality".

63. Weston, Tom. "Manhire's Scalpel-Fine Slashes of Language". Review of My Sunshine and Sheet Music: Poems 1967-1982, by Bill Manhire. Press (Christchurch) (31 August 1996): sec. weekend, p. 14.

Discusses the preface quote by Sterne and it's relationship to the poems. Comments on the different responses readers of the book might have, and explores how each of these sentiments may apply to the book. Comments on digressions, set exercises and conceits. Examines "Isabella Notes", variations of the name, the lexicographer, the use of the alphabet, and history. Mentions "An Amazing Week in New Zealand" and it's "scalpelfine slashes of language". Briefly discusses the scope of Sheet Music: Poems 1967-1982, noting particularly the work in Good Looks. 
Includes head photograph of Manhire.

64. Wyatt, Hamesh. "Wistful and Witty Anthologies Never Disappoint". Review of Sheet Music: Poems 1967-1982 and My Sunshine, by Bill Manhire. Otago Daily Times (4 May 1996): 22.

Quotes "The Occupation Against Time". Mentions the use of "irony, hope and wistful resignation". Touches on his love poems and early motifs. Quotes "The Caravan" and mentions "Colloquial Europe" with the shared image of crayons. Comments on his use of surprise and Antarctica, noting "An Amazing Week in New Zealand" and "Hoosh". Examines the use of singing in "An American Marriage", "Magpie Crooning" and "Red Dream". Briefly mentions his "love" and quotes from "My Sunshine".

See also: $67,73,74,96,107,132$

\section{Songs of My Life. Auckland: Godwit Publishing Ltd, 1996}

65. Cooper, Ronda. "Books: History Repeats - Ronda Cooper Defends the Practice of Recycling”. Review of Songs of My Life, and My Sunshine, by Bill Manhire. Metro, no. 182 (August 1996): 109-111.

Briefly discusses "The Brain of Katherine Mansfield" and "Wings of Gold: A Week Among Poets". Examines the use of "the borderlines between convention and incomprehensibility, between cliché and total alienness". Touches on My Sunshine and the use of conventional rhetoric. Describes the writing as making the reader uncomfortable.

66. Crowl, Mike. "Readable Stories Raise Issue of 'Obscurantism'”. Review of Songs of My Life, by Bill Manhire. Otago Daily Times (10 August 1996): 28.

Questions the meaning of the pieces, and their relationship to extended prose poetry. Compares Manhire's style to the tradition of New Zealand literature "telling us something without telling us". Discusses the value of obscurantism in general. Describes book as intriguing, amusing and entertaining.

67. Garrett, Simon. "The Gifts of Bill Manhire". Review of Songs of My Life, My Sunshine, and Sheet Music, by Bill Manhire. Dominion (16 March 1996): 20.

Discusses the connection between Manhire's poetry and the stories in Songs of My Life, in particular the use of irony, words, and meanings. Comments on "Wings of Gold: A Week Among Poets". Briefly mentions My Sunshine and Sheet Music. 
Includes head and shoulders photograph of Manhire.

68. Hill, David. "Books in Brief". Review of Songs of My Life, by Bill Manhire. New Zealand Herald (9 March 1996): sec. 7, p. 6.

Describes Manhire as "a writer for whom words are often the message and the medium". Discusses the use of language in general, including irony, understatement and clichés. Mentions that occasionally the cleverness of the writing overshadows the topic.

69. Scott, Bede. "Soul Music". Review of Songs of My Life, by Bill Manhire. Quote Unquote, no. 34 (April 1996): 26-27.

Mentions the diversity of the collection in theme and style, noting "Wings of Gold: A Week Among Poets", "Highlights" and "Flights of Angels". Discusses the idea of "internal incongruity" in "Ponies" and "Cannibals". Comments on Manhire's use of the potential of language and his "deeply sympathetic vision of people and the imperfect world they inhabit". Briefly explains the comic element of "Wings of Gold: A Week Among Poets". Mentions the exercise quality of "Some Questions I Am Frequently Asked".

\section{Sharp, Iain. "Splendid Send-Ups". Review of Songs of My Life, by Bill Manhire. Evening Post (8 March 1996): 7.}

Explains the connection between Songs of My Life and the volume South Pacific published by Carcanet in Britain. Mentions the use of satire in "The Poet's Wife", "The Brain of Katherine Mansfield", and "Some Questions I Am Frequently Asked".

Discusses the storyline of "The Moon at the End of the Century". Identifies the mood of the book as "one of playful mockery" (with the exception of "Ponies"). Mentions the treatment of being a New Zealander, and celebrities mentioned or implied in the stories. Identifies the omission of the index which was present in The New Land: A Picture Book, and the drawings from The Brain of Katherine Mansfield.

71. Wevers, Lydia. "Very Carefully Sidelong Postmodernism". Review of Songs of My Life, by Bill Manhire. New Zealand Books 6 no. 5 (December 1996): 1, 3. Also in Under Review: A Selection From New Zealand Books 1991-1996, Canterbury: Lincoln University Press, 1997.

Briefly discusses Manhire's work as postmodern. Examines the idea of a seemingly simple text with "hidden complexities, attitudes, inflections". Mentions the use of grammar, vocabulary, genre and style referring to "Cannibals". Discusses the idea of Manhire's work selectively using "postmodern techniques" as opposed to entirely 
postmodern. Names “The Poet's Wife", "Some Questions I am Frequently Asked", "Nonchalance" and "The Brain of Katherine Mansfield" as the most postmodern and notes their postmodern characteristics. Explores "The Brain of Katherine Mansfield", the use of boundaries and the satire in using a "stories for boys" genre". Discusses "Some Questions I am Frequently Asked", the use of the anonymous interviewer and interviewee, intertextuality, and its postmodern characteristics. Briefly discusses Manhire's use of New Zealand references including events, geography, and speech patterns. Discusses the use of poets in "The Poet's Wife", "The Moon at the End of the Century", "Songs of My Life", and "Wings of Gold: A Week Among Poets". Briefly mentions the use of last lines in the stories. Explores "Wings of Gold: A Week Among Poets", the role of the author in the story, and irony. Comments on the experience of being in another culture and Manhire's handling of this. Mentions the absence of politics in Manhire's postmodernism.

Original includes head and shoulders photograph of Manhire.

See also: $60,62,114,129,132$

\section{My Sunshine. Wellington: Victoria University Press, 1996.}

\section{AJF. "821 MAN NZ". Review of My Sunshine, by Bill Manhire. New and Notable 14, no. 2 (May 1997): 20.}

Discusses the Lawrence Stern quotation which prefaces the collection and its relationship to the poems. Mentions the topics including "Antarctica, ancestors, religious crusades, growing up, [and] generations". Briefly discusses "Blade \& Swing". Recommends promoting the collection by studying poems in class.

73. Bland, Peter. "Elegant Surprises". Review of My Sunshine and Sheet Music: Poems 1967-1982, by Bill Manhire. Quote Unquote, no. 34 (April 1996): 26.

Discusses the title Sheet Music. Briefly mentions the use of direct statements, and compares their use to that of Robert Bly and James Wright. Explores the idea of "New Zealandness" in the poetry. Describes the "concept" in Manhire, including Antarctica, Hirohito, Isabella, Billy Graham. Comments on "Hirohito", "Isabella Notes" and "Hoosh" as longer poems. 
74. Newton, John. "Risks, Rewards in New Poems". Review of My Sunshine and Sheet Music: Poems 1967-1982, by Bill Manhire. Evening Post (8 March 1996): 7. Also at http://www.arts.uwo.ca/ andrewf/clippings/manhire4.htm [Accessed 02/01/03]

Describes My Sunshine as containing "sidelong estrangements of Kiwiana, postmodern landscapes, dictionary poems, short lyrics hedged in sardonic endgame, and flashes of strikingly translucent family research". Discusses "An Amazing Week in New Zealand" and "Hoosh". Compares Manhire's new longer poems to the best of his shorter works, and the retention of density and urgency. Describes contents of Sheet Music.

Includes head and shoulders photograph of Manhire.

75. Scott, Bede. "Manhire Collection a Shining Light". Review of My Sunshine, by Bill Manhire. Sunday Star-Times (26 May 1996): sec. E, p. 4.

Discusses light in relation to the collection. Compares Manhire to Ezra Pound.

Examines the use of pathos in "Hoosh", and "An Amazing Week in New Zealand".

See also: 59-65, 67, 92, 96, 99, 107, 132, 166, 168

\section{Homelight: an Antarctic Miscellany. Karori: Pemmican Press, 1998.}

76. AFP. "Polar Landscape Inspired Poetry". Otago Daily Times (31 March 1998): 13.

Describes Manhire's experience of Antarctica on the Artists to Antarctica scheme. Includes comments on the landscape, time, Scott's hut and the South Pole. Mentions the time frame of writing of the poems.

Includes head and shoulders photograph of Manhire.

77. Allison, John. "Of Ice-blinks, Blackbirds, and Ikebana". Review of Homelight, by Bill Manhire, Nigel Brown, and Chris Orsman. New Zealand Books 8 no. 3 (August 1998): 18-19.

Quotes "Antarctic Stone", and Eliot on form and "evasion of monotony", comparing Manhire's poems to the quote. Mentions his use of language and humour. 


\section{8. "The Unframed Continent: Artist in Antarctica". Produced by Natural} History New Zealand Ltd, 55 min., 1999, Video recording.

Discusses the views and myths of Antarctica. Records their visit to Cape Royds and Shackleton's hut. Manhire comments on the visitors book as "ironically inspiring", and reads "Visiting Mr Shackleton". Notes Manhire's observation of the indifference of nature, which inspires "Listen Nigel" (also read). Visits Scott's hut, and comments on Manhire's use of icy death to represent a mother to Scott, reading "The Polar Explorer's Love Song". Shows the origins of the name Homelight for the collection. Mentions his "scavenging" of glaciological terms. Discusses links between the way a scientist and a poet work, and the writing of "Deep Field Song". Shows radio interview on the ice, with Manhire discussing the "endless white, endless light", and his uncharacteristic use of rhyme to bring his own system into order. Shows the publishing of the first edition of Homelight. Gives his final impression as that of "a place that is totally unframed" and "that has no edges".

See also: 168

\section{What to Call Your Child. Auckland: Random House New Zealand, 1999.}

\section{Arvidson, Ken. "How to Keep Your Secret". Review of What to Call Your} Child, by Bill Manhire. New Zealand Books 10 no. 1 (March 2000): 15-16.

Mentions the cover, and the reproduction of Hotere's "Drawing of Bill Manhire" (1972), noting, Malady. Discusses the epigraph, and its relationship with the work. Explores the idea that Manhire's work has a "commitment to inconsequentiality" and musicality, rather than meaning. Quotes from the Oxford Companion to New Zealand Literature, Andrew Johnston and Steve Braunias. Discusses Part 1 of What to call your child, as "lyrical fictions", noting the romantic and the sad in the poems.

Compares the title poem, "What to Call Your Child" with "How to Take Off Your Clothes at the Picnic". Discusses "What to Call Your Child" noting the storyline. Notes the use of recurring images, quoting "Picnic at Woodhaugh" and the economy of words. Mentions "Landscape with Bride", "Inesilla", "Grapes" and "The Album", commissioned for the $200^{\text {th }}$ anniversary of Pushkin's birth.

Notes "Antarctic Stone" and "The Polar Explorer's Love Song" and their appearance in Part 3, rather than 2 with "Antarctic Field Notes". Mentions the change in style in "Antarctic Field Notes" from Part 1. Comments on a "Manhire species of poetry". Briefly mentions "Field Notes", comparing it to Chris Orsman's South: An Antarctic Journey and Black South. Describes his Antarctic poems as "un-Manhire-like monochromatic realism".

Briefly mentions "Luck: A Villanelle" and it's origins. Notes "Riddle" and the influence of the Anglo-Saxon work on his poems. Comments on "Domestic" and the relationship 
between domesticity and "relationships and emotions". Discusses the collaborative poem "Colin".

Includes torso photograph of Manhire.

80. Brown, James. "Manhire Still a Unique Talent". Review of What to Call Your Child, by Bill Manhire. Evening Post (22 October 1999): 5.

Describes What to Call Your Child as "intensely beautiful .. both disguising and initiating a subtle post-modernism". Comments on the allusive and accessible nature of the poems. Discusses "Arctic Field Notes" and compares these poems with "Hoosh" (written before going to the Antarctic).

81. Hulse, Michael. "Reviews". Review of What to Call Your Child, by Bill Manhire. Landfall, n.s., 8, no. 1 (March 2000): 115-117.

Discusses minimalism, reverence and quiet in the poems. Mentions the use of the image of the moon and the "soft grey air" in his poetry (particularly "The Adventures of Hillary"). Comments on lyricism in relation to "Inesilla" and rhyme in "The Buried Soap, "Aubade", "Cape Royds", "Pledge", and "The Polar Explorer's Love Song". Contrasts "A Scottish Bride" with "A Song about the Moon", and "Picnic at Woodhaugh" with "Out West".

82. Riach, Alan. "Poems that Sneak Up on You". Review of What to Call Your Child, by Bill Manhire. Dominion (16 October 1999): 20.

Discusses the ironic and "cool" qualities of Manhire's poetry, particularly in "Antarctic Field Notes" and the use of words such as "horizon, ice, white, air, stone, snow, sky, hut" in the series. Comments on "Food Chain", "Aubade" and "The Album". Mentions the subject of some of the poems including the Anglo-Saxon riddles, Colin McCahon's Storm Warning and "Luck: A Villanelle".

Includes torso photograph of Manhire.

83. Ritchie, Beck. "Breathing Made Visible in the Cold Antarctic Air". Review of What to Call Your Child, by Bill Manhire. Otago Daily Times (1 December 1999): 24.

Describes the poems as simplistic and almost Japanese. Explores "Antarctic Field Notes" and their minimalist, note-like form, mentioning "Current". Notes the use of "spaces, sparseness and silences". 
Includes book cover shot.

84. Weston, Tom. "Risking All on Erebus". Review of What to Call Your Child, by Bill Manhire. Press (Christchurch) (1 April 2000): 10.

Discusses "Antarctic Field Notes" and the adequacy of the language used. Mentions "Blood Falls". Compares What to Call Your Child to his recent collections and their tendency to "play games". Likens Manhire to Leunig (Australian cartoonist).

Includes head and shoulders photograph of Manhire.

See also: 95-97, 128, 132, 168

\section{Collected Poems. Wellington: Victoria University Press, 2001.}

85. Baskett, Pat. "Reviews". Review of Collected Poems, by Bill Manhire. Art News 21, no. 3 (Spring 2001): 38.

Briefly mentions the presentation of the poems, and compares the early to the later poems. Briefly discusses the range of the poems mentioning "Hirohito", "Hoosh" and "Deep Field Song" and the their other genre-like qualities.

86. Eggleton, David. "Stone upon Stone". Review of Collected Poems, by Bill Manhire. New Zealand Books 11, no. 5 (December 2001): 9.

Comments that the poems may require many readings "for them to fully reveal themselves". Describes the contents of the collection. Discusses "The Next Thousand" and the harmony between Manhire's poetry and New Zealand's current mood. Examines poems from The Elaboration and the use of images. Quotes "Summer" as an analogy for Manhire's poetry, and the repetition of certain words throughout his poetry. Considers the use of "stone", noting "Watching Alison in Winter", "Last Things" and "Antarctic Stone". Quotes "Poem". Notes the use of the word "forest", mentioning "Moonlight". Discusses the use of conceits, mentioning "Isabella's Notes" and "South Island Companion", as well as noting poetic devices. Explores the idea that Manhire stays with "a few themes ... on which endless variations are played", commenting on his attitude to language. Discusses his use of repetitive images and experience, quoting "Wingatui".

87. Gadd, Bernard. "Collected Poems (Book)". Review of Collected Poems, by Bill Manhire. World Literature Today 76, no. 2 (Spring 2002): 144.

States that "Publishers exaggerate Bill Manhire's place in the past and present of New Zealand poetry". Explores his early poetry, noting lyricism, statements, imagery and use 
of "final line stress". Notes moods such as solitariness and displacement. Discusses "Phar Lap" and the use of puns. Examines "What to Call Your Child", a lack of energy, and an avoidance of serious issues. Briefly mentions "Luck: A Villanelle", "Hoosh", "The Next Thousand", "Wulf" and his Pushkin translations. Comments on his use of haiku.

88. Hall, Bernadette. "New Sophistication for a Daggy Kiwi Phrase". Review of Collected Poems, by Bill Manhire. Evening Post (7 September 2001): 9.

Mentions the use of Kiwi phrases and of New Zealand themes such as "Phar Lap, Sir Edmund Hillary, the war... Billy Graham...Antarctica". Briefly discusses "On Originality" and the idea of poet as thief, mentioning Charles Simic, Wallace Stevens, Denis Glover and Stevie Smith. Comments on the idea of icons including the clown, explorer, hero and cowboy. Briefly mentions "Hoosh".

Includes head and shoulders photograph of Manhire.

89. Palmer, Rebecca. "Book Marks". Review of Collected Poems, by Bill Manhire. Otago Daily Times (13 October 2001): sup., 39.

Mentions Manhire's status in New Zealand poetry and the creative writing course at Victoria University of Wellington. Describes the collection and its contents. Comments on Manhire's use of words.

90. Rabbitt, Lindsay. "When You're Dead You Get Collected." Listener 178, no. 3182 (5 May 2001): 51.

Discusses the simultaneous publishing of Collected Poems by Carcanet and Victoria University Press. Explains the contents of Collected Poems, the arrangement of the poems and additions to the volume. Mentions Manhire's inclusion in Book of TwentiethCentury Poetry in English (Harvill). Briefly discusses the idea of reworking earlier poems.

Includes torso photograph of Manhire.

91. Roberts, Hugh. "Wild Bill Rides Again". Review of Collected Poems, by Bill Manhire. Listener 180, no. 3204 (6 October 2001): 58-59.

Mentions the idea of the "Manhire era", and his influence on New Zealand literature. Discusses briefly the creative writing course. Explains the story of "Wingatui" (poem reprinted), and "Pseud's Corner". Explores the idea of mystery in his poetry. Mentions the influence of John Ashbury on Manhire, mentioning "The Poetry Reading”. 
Comments on the use of recurring words including bone, stone, moon, tree, water, river, rain, considering "Water, A Stopping Place", and the absence of these items in his later poetry. Mentions "Allen Curnow meets Judge Dredd", "Isabella Notes", "Synopsis (Handel's Imeneo)". Discusses the Antarctic poems at the end of the collection, and finding the language to describe the landscape.

Includes head and shoulders photograph of Manhire.

92. Robinson, Peter. "Distance, Loss, Links". Review of Collected Poems and Doubtful Sounds: Essays and Interviews, by Bill Manhire. Jacket 16 http:/www.jacket.zip.com.au/jacket16/nz-robi-manh.html [Accessed 19/6/02].

Discusses the "'Wingatui' Incident", and explores the poem in general (reprinted), particularly the language used and the possible metaphors in the poem. Reprints extract from The Elaboration authors statement. Comments on the idea of the "fact-fiction contrast". Examines Good Looks, particularly "Wellington", and the subject matter. Mentions the idea of distance in this collection. Briefly mentions "The Voyeur: An Imitation" and "The Late Victorian Girl". Quotes an interview with Gregory O'Brien regarding his work with Ralph Hotere. Describes the works in Good Looks as "more sure of themselves, their directions, and their purposes in existing", and notes the effect that fatherhood may have had on this, specifically "Children" and "The Next Thousand".

Mentions Milky Way Bar and My Sunshine. Quotes an interview with Iain Sharp regarding mystery and growing up in Dunedin in the 1950/60's. Discusses "An Amazing Week in New Zealand" in relation to mystery, and Christianity, and draws a parallel to Denis Glover's “The Magpies”.

Comments on the idea of distance and loss in "Moonlight". Talks about the avoidance of "nation-founding themes" in Manhire's early poetry and its emergence in his mid-career poetry, along with his family background noting "The Scottish Bride" and "Zoetropes". Includes quote from Manhire on the work of Craig Raine. Explores "Breakfast" and notes Manhire's use of three-line stanzas. Examines the idea of distance in "Breakfast" and distance and loss in "Wingatui".

Includes torso photograph of Manhire.

औ

See also: 132,168 


\section{$\underline{\text { General }}$}

93. Barbour, Douglas. "Writing Through the Margins: Sharon Thesen's and Bill Manhire's Apparently Lyric Poetry". Australian and New Zealand Studies in Canada, no. 4 (Fall 1990): 72-87. Also at http://www.arts.uwo.ca/ andrewf/anzsc/anzsc4/barbour4.htm [Accessed $02 / 01 / 03]$

Reproduces "Declining the Naked Horse". Mentions the poetry's "duplicitous unwillingness to guarantee anything" and this quality in contemporary poetry. Discusses the similarities of Thesen and Manhire's writing "on Imperial margins... both inheriting and resisting the necessities of The Great Tradition". Examines their use of the lyric and how they fit into the "lyric poets" category. Comments on their having a "private voice'. Notes the use of politics in poetry, referring to "Wellington" and its use of line breaks, demotic speech, the use of "you" in the poem, and humour. Discusses the awareness of both poets of the English Literary Tradition, mentioning "The Poetry Reading" and the use of signifiers.

Explores Manhire's use of titles including The Elaboration, How to Take Off Your Clothes at the Picnic, Good Looks, and Zoetropes, and both authors use of cliché. Examines Manhire's tone when "tak[ing] on the British tradition of poetic uplift" in "The Buried Soap", referring to Manhire's use of Matthew Arnold's poem "The Buried Life" and his take on its "truth'. Comments on his "comedy of deflation", referring to "The Buried Soap" and "On Originality".

Discusses "Water, A Stopping Place" and the use of narrative and perspectives. Mentions the final lines of the poem, and the juxtaposition of creating "both insecurity in and acceptance of the world".

\section{Bieder, Penelope. "Revealing Our Man of Letters". NZ Herald (24 August 2002): sec. G, p. 2.}

Provides an outline of the creative writing courses. Gives a biographical outline, and suggests a connection between his upbringing and his talent at teaching writing. Mentions why he feels poetry is important, and the role of imagination in New Zealand. Discusses his interest in Antarctica. Briefly mentions "Cannibals" and its origins. Comments on the role of the poet in society.

Includes a head and shoulders, and a full length photograph of Manhire. 


\section{5. "Bill Manhire". Contemporary Poets. St James Press, 2001. Biography Resource Centre, Gale/K1660001218.}

Describes Manhire's poetry as wry, ironic and lyrical, with a balance between "playfulness and nostalgia". Characterises his poetry as creating an expectation which is then subverted, noting "Summer". Discusses his prose, mentioning it's romanticism, and recurring images. Mentions his use of "whimsy, inconsequentiality, puns, jokes on grammar, and scraps of pop culture and the New Zealand vernacular". Briefly mentions his use of hesitancy, and the poetry it produces, quoting "Zoetropes. Explores the use of "small effect", mentioning "A Scottish Bride", "The Voyeur" and "The Song". Mentions his use of the playful and seriousness, and the trivial. Discusses his use of clichés, noting particularly "The Pickpocket", "The Poetry Reading", "Vanessa's Song", and quoting "The Swallow". Comments on the role of the reader, and the effect of frustration and puzzlement that the poems may cause. Explores sources, noting America and "On Originality". Discusses his use of pop culture, slang and grammatical errors, noting "Declining the Naked Horse" and "Visiting Mr Shackleton" and its composition. Mentions the use of mockery in "An Amazing Week in New Zealand" and "The Adventures of Hillary". Comments on his later use of narrative and topical events, noting What to Call Your Child. Summarises his work to date, provides biographical information, and a select bibliography of critical readings.

96. Braunias, Steve. "Wild Bill”. Listener 171, no. 3105 (13 November 1999): 3639.

Discusses trip to Antarctica. Briefly mentions Doubtful Sounds, My Sunshine, The Brain of Katherine Mansfield and the use of "tricks, japes, [and] childish delights". Compares new poems to the style of older work (Sheet Music: Poems 1967-1982). Explains the origins of "What to Call Your Child", "The Pickpocket", "Luck: A Villanelle", "Out West" and What to Call Your Child. Manhire talks about hearing "the poem first as music". Mentions poems as biographies in Milky Way Bar. Discusses piece written by John Newton about Manhire and the poem as putting something between writer and reader. Comments on the accessibility of poetry. Explores the influence of Robert Creeley. Mentions Mutes and Earthquakes.

Includes two photographs (one head and shoulder, one $3 / 4$ shot), and reproduces "Luck: A Villanelle" and "The Pickpocket".

\section{Brown, James. "“Aha - Data Reduction!"' New Zealand Books 10, no. 2 (June} 2000): 12.

Interview with Manhire. Talks about how writing with the audience in mind affects the work. Discusses the meaning of "A Final Secret". Briefly explains the way a poem originates and writing habits. Explores his short story writing, and its influence on narrative in his poetry . Comments on the return to his earlier style of short lyric poems 
in What to Call Your Child, mentioning "Luck: A Villanelle" and "Millennial". Discusses what English departments should be teaching, and aesthetics versus literary theory. Talks about the poet laureateship and its influence on Manhire in taking a more public role. Mentions the quality of current New Zealand poetry and Manhire's influence on the "Wellington School".

Includes one head and shoulders photograph of Manhire.

\section{Caffin, Elizabeth. "Manhire, Bill". In Encyclopedia of Post-Colonial Literatures in English, ed. Eugene Benson and L. W. Conolly. London: Routledge, 1994: 971-2.}

Mentions Manhire in connection with Ian Wedde. Discusses the economy of the poetry and each poem as an independent "artefact". Comments on the use of mystery and magic and the song-like qualities. Mentions "The Pickpocket" and "The Mutability Cantos". Explores the use of tone, context, register and cliché. Notes links in poems to Manhire's "personal, domestic, and literary life", mentioning Good Looks, "Children". Briefly mentions his fiction including The Brain of Katherine Mansfield and The New Land: A Picture Book, and their content as "how contemporary New Zealanders see themselves and how others see them".

\section{Caffin, Elizabeth. "Poetry: Part Two-1945-1990s". In The Oxford History of New Zealand Literature in English, ed. Terry Sturm. Auckland: Oxford University Press, 1998: 447-524.}

Mentions The Elaboration as an illustration of how Manhire sees the poem. Contrasts Manhire to Wedde. Characterises his poetry as "brief, apparently simple in syntax and vocabulary, usually without regular patterns of metre or rhyme, and very often strangely enigmatic and elliptical". Notes the influence of Creeley on line length and phrasing. Compares his use of cliché and idiom to Wedde, and mentions his use of mimicry. Discusses the relationship between the language and the world, including the use of allegory. Mentions Malady and the use of wordplay, and found phrases in "The Pickpocket" and "The Cinema". Comments on themes including love poetry in The Elaboration, and death and family in Good Looks. Explores the shifting function of language and meaning, noting "Declining the Naked Horse", "The Buried Soap" and "Children". Mentions the song-like qualities of some poems and common imagery including "snow, stars, water, and stones". Discusses the use of "you" and "I" and the presence of Manhire in the poems. Compares Manhire's structure, detail and humour to Charles Spear.

Notes his "alertness to the possibilities of so many language registers". Examines "The Poetry File" and its relationship with his poems, noting Milky Way Bar and My Sunshine. Briefly discusses his fiction, noting "Hoosh" and his use of autobiography, geography and history. Mentions the preface to My Sunshine and its relationship to the poems. 
Discusses the sense of sharing in his writing including language, icons and family, quoting "Magasin". Comments at length on the "Manhire school" of poetry. Notes commonalities in a wider context with "Jenny Bornholdt, Dinah Hawken, Chris Orsman, [and] James Brown", but describes his influence as "loose and capacious".

\section{Cochrane, Kirsty. “On the Map: Vincent O'Sullivan, Fleur Adcock, Bill Manhire, Ian Wedde". Journal of New Zealand Literature, no. 2 (1984): 59- 74.}

Explores Manhire's experimentation with open-form poetry. Discusses The Elaboration, the theme of love and the relationship between the title and the theme. Mentions "Poem", "The Elaboration" and "Pavilion" in relation to the imagery and the refining of language. Briefly notes the use of lines. Examines "The Importance of Personal Relationships", the use of the enigmatic and the use of clichés. Asks questions regarding the nature of communication. Comments on the relationships present in poems in How To Take Off Your Clothes at the Picnic including "children, friends, the world, the heavens, poetry itself", referring to "On Originality". Discusses the use of silences and gaps, "what he chooses and does not choose to say". Briefly mentions the use of the twolined sentence in Good Looks and "Children".

\section{Crisp, Peter. "Pavlova \& Wrists: the Poetry of Bill Manhire". Islands 7, no. 2} (November 1978): 189-195.

Discusses Manhire's writing "for an attractively possible voice" (italics in original). Mentions his use of intonation and "intuitive gap[s]", and names Curnow and Wedde as other practitioners. Characterizes his work "by the quick play of a deceptively simple language, and a tone of ambivalent politeness". Quotes from "The Collection" regarding the use of fantasy. Discusses the use of humour, mimicry and mockery.

Comments on The Elaboration as love-lyrics and their phrasing, quoting from "The Voyage". Mentions his use of little words. Quotes from "The Prayer" and the use of language and images. Implies the use of humour in "The Spell". Discusses in general the lyricism and use of language in The Elaboration, quoting "Watching Alison in Winter" and mentioning the use of French intonation and parody.

Examines the use of humour in How to Take Off Your Clothes at the Picnic quoting "The Collection". Mentions the use of the surreal and incongruous, quoting "The Procedure". Notes the directness and character in this collection compared to The Elaboration. Discusses the use of brevity in "The L \& R song". Mentions the illustration of the cover and the relationship between it and the poems. Comments on the three sections as "representing three stages of emotional growth; and of poetic development", identifying the main theme of each section and the characteristics of the poems. Quotes from "Clouds" and "The Song" in the third section. Discusses the images of water, quoting 
from "The Trees" and "The Coast". Comments on the sustained tone of the collection, quoting "The Song".

102. Dhawan, R. K., and William Tonetto. "New Zealand Poetry from "Then" til "Now"". New Zealand Literature Today. New Delhi: Indian Society for Commonwealth Studies, 1993: 184-186.

Discusses "A Scottish Bride", in relation to history, and the way questions are asked in the poem. Examines the use of the word "genealogy" and Foucault. Briefly mentions the use of naiveté, and the themes of distance and isolation.

103. Eggleton, David. "Boxing the Compass". Review of four, by Bill Manhire, Damien Wilkins, Elizabeth Knox and Emily Perkins. New Zealand Books 6 no. 3 (August 1996): 7-8.

Discusses "Hoosh". Mentions the use of humour, and posits the idea that his role as an anthologist "present[s] the possibility that he's a completist, a maker of mandalas". Comments on the use of detail in "Hoosh", and the recurrent theme of white.

\section{Fifield, Anna. "Bill Manhire - a Poet on Ice". Evening Post (10 January 1998): 10.}

Discusses Manhire's upcoming trip to Antarctica. Talks about the place of Antarctica in New Zealand's imagination. Mentions the historical significance of the places that will be visited on the trip.

105. Gibson, Simon. "Manhire on Ice". Salient 61, no. 2 (9 March 1998): 22. Also at http://www.geocities.com/ResearchTriangle/Lab/4913/bill.html [Accessed 19/01/03].

Discusses his visit to Antarctica. Briefly mentions the relationship between Antarctica and New Zealand. Comments on the role of Antarctica in literature, and his writing of poetry there. Explores the interviewers idea of Manhire's poetry being "ideally suited to a particularly middle class kind of audience".

Original version also includes head and shoulders photograph of Manhire, and reprint of “The Polar Explorer's Love Song". 
106. Gifkins, Michael. "Sometimes Answered". Listener 127, no. 2622 (11 June 1990): 110-112.

Comments on Manhire's transition into short stories and the similarities between these and his poetry including the use of humour and "the refusal at any traditional level to be taken seriously". Examines "Highlights" and the climax of the story. Briefly mentions The Brain of Katherine Mansfield and disjunctions, and "Some Questions I Am Frequently Asked" and the existence of the writer in the text.

107. “Good Morning”. Produced by Kotuku Productions. Series 1, Programme 106, 11 min. (10:05:01-10:15:51), 1996, Video Recording. (TVNZ Archive, P174578)

Discusses My Sunshine, mentioning the origin of the title, the poem of the same name, and Manhire wanting to convey that poetry is part of the "entertainment industry". Comments on the title of Sheet Music: Poems 1967-1982. Explores Manhire's writing habits and the conditions needed. Describes poetry as a "way of finding out for myself about a whole lot of things that I didn't know". Posits that if you don't know what you want to say, words are part of the process of finding out. Examines "My Sunshine" noting it is about "someone a bit like me, but it's not me". Discusses the poem being about a romantic, idealised notion, in which life doesn't measure up. Reads the "My Sunshine". Comments on the way poems are read by poets, and poetry as being both sophisticated and primitive.

108. Gray, Stephanie. "It's the Milky Way Kid...". Salient 55, no. 17 (27 July 1992): 10-11.

Briefly mentions early writing influences. Discusses his sources of inspiration. Explores the "autobiographical element" in his writing. Comments on Milky Way Bar and his use of imagination. Examines the idea of an audience and messages and themes. Describes The Brain of Katherine Mansfield, the origins of the point of view, the pick-a-path genre and the New Zealand audience.

Includes head photograph of Manhire.

109. Horne, Daniel Richard. "Letters from America: the Influence of Specific Post-World War II American Poetry and Poetics on those of New Zealand and Scotland as Exemplified in the Poetry of Bill Manhire, Ian Wedde, Tom Leonard and Edwin Morgan". Master of Arts, University of Waikato, 1993.

Discusses Manhire's imitation of poets and the development of his own style. Mentions the influence of Old English poetry and notes the identification of New Zealand in his poetry and prose. Contrasts Manhire and Curnow and their views on the English Literary 
tradition, quoting and commenting on "The Swallow" as an example. Comments on the way in which he resists academic discourse, noting "The Idiot: A Pastoral". Mentions "The Anglo-Saxon Onion", "Wen", and "Wulf" as more traditional. Discusses Creeley's influence, quoting "Love Poem" and examines its lineation and syntax, comparing it to "Hello" by Creeley. Contrasts Manhire's use of "I" to Creeley's. Discusses both writers use of "contrasting the "profound" with the banal or everyday concern", comparing "I Know a Man" with Manhire's "Magasin" and the use of code-switching. Briefly mentions "The Idiot: A Pastoral", "The Afterlife", and "The Importance of Personal Relationships". Examines his use of cultural artefacts, discussing "Magasin" and "On Originality". Comments on his use of images in "Poem". Compares and contrasts Creeley's "The Riddle" with Manhire's "Riddle", noting the role of mystery, games, solutions, clues and similes. Discusses perspectives, quoting "A Song About the Moon". Compares Manhire and Creeley in their use of lineation, noting "The Voyeur: An Imitation" and "The Late Victorian Girl".

\section{Horrocks, Roger. " "Natural" as only you can be': Some Readings of contemporary New Zealand Poetry". And, no. 4 (October 1985): 101-123.}

Compares Manhire to Wedde and McQueen. Discusses the title Zoetropes throughout and its relationship to the poems. Mentions the use of clichés and the hypothetical, quoting "Summer" and "The Voyeur: An Imitation". Classifies his poetry as modernism. Explores the idea of the "gap between language and the world" and language and reality, quoting "The Afterlife". Discusses the idea of Modernism and Structuralism in reference to Manhire's poetry. Briefly mentions "Wellington" and its political theme. Comments on his use of humour and realism in "It Is Nearly Summer" and its resemblance to Wallace Stevens' "Thirteen Ways of Looking at a Blackbird". Discusses the images in relation to cartoon characters and zoetropes.

Mentions the "under-read[ing]" of Manhire's work, including the publishers blurb from Good Looks. Notes Wedde's reading of "Wingatui" and its use of context and referents. Examines "Water, A Stopping Place", in relation to a 'local' reading and notes similarities with Curnow's "Lone Kauri Road". Undergoes a detailed "modernist" reading of "Water, A Stopping Place". Discusses the title, the use of water and "river", changes in perspective, realistic and emblematic readings, under-reading and overreading, the changing usages of words, the ending and lyricism, open text, and the use of nostalgia.

\section{Hurley, Jane. "That Poetry Effect". Listener 164, no. 3038 (1 August 1998):} 58.

Mentions the effect of fairy-tales and folk tales on Manhire. Discusses "the idea that poets can act as a sort of weather forecaster for the age". Examines the concept of poetry as separate from the commodity culture. Explores the mysterious quality of the poetry. 
112. Isaacs, Clarke. “'Dirty' Path away from Poetic Purity”. Otago Daily Times (6 June 1992): 18.

Review of Dirty Silences, first in the Talking of Poets series on Concert FM. Manhire explores the idea that poetry's last task is to "refine or purify or clarify". Discusses the use of language, its use and misuse by advertising and politics, and the duty of the poet to keep language "fresh, accurate, truthful and usable". Mentions the idea of purity as dangerous. Posits the idea that poets practised impurity, though yearned for purity.

113. Johnston, Andrew. "Entertaining Possibilities: Six Contemporary New Zealand Poets". Meanjin 51, no. 3 (Spring 1992): 641-652.

Discusses the idea of language at play, in contrast to Curnow, noting "Hirohito". Mentions the use of "exhausted and repetitious phrases and situations". Compares Manhire to Curnow in their use of uncertainties in language, mentioning "Synopsis (Handel's Imeneo)". Explores the influence of American poets on Manhire and New Zealand poets. Briefly compares Manhire's poetry to Dinah Hawken.

\section{Johnston, Andrew and Bill Manhire. "Afterword: An E-mail Interview with Andrew Johnston". In Doubtful Sounds: Essays and Interviews, by Bill Manhire. Wellington: Victoria University Press, 2000: 282-289.}

Mentions his use of commissions as a motivator. Discusses his dislike of "the high romantic affectations that are attached to the idea of "the Poet". Notes triggers for poems, including reading poets and writing a lot. Comments on the use of constraints to create possibilities. Examines the idea that some critics may "mistake mystery for decoration" and respond by "complaining that the poet has nothing to say". Discusses his views of opacity and transparency. Mentions the place of music in a poem, and names Michael Palmer as his favourite Language poet. Comments on his preference for lyric rather than narrative, and his liking for humour and melancholy, mentioning Philip Larkin, John Ashbury and Larissa Szporluk. Briefly discusses Songs of My Life. Notes the way The Brain of Katherine Mansfield works in hypertext. Discusses his interest in Antarctica and his work on a bibliography and anthology. Comments on the origins of some of the interviews, lectures and columns.

115. Jones, Belinda. "Exhibitions Archive 2000".

http://www.christchurchartgallery.org.nz/Resources/ExhibitionsArchive/200 0/Quotations/ [Accessed 19/01/03].

Discusses the relationship between text and images. Comments on Hotere's use of Dawn/Water, the arrangement of the poem, and the addition of "Mururoa", to alter the "neutral" meaning of the poem. Compares it to the Malady paintings. 


\section{Karavasil, Josie. "Manhire Call to Abandon Poetry". http://www.wnw.quik.co.nz/rossco/poetrycafe_review_september_02.htm [Accessed 19/01/03].}

Quotes from "A Song about the Moon". Discusses his use of playfulness and common ideas in different contexts. Briefly mentions "Visiting Mr Shackleton", "Wellington", and "Luck: A Villanelle". Examines "The Next Thousand", and the use of "prophecies".

117. Keene, Howard. "Poets and Painter to Seek a New View of Antarctica". Press (Christchurch) (20 January 1998): 5.

Discusses the upcoming trip to Antarctica of Bill Manhire, Chris Orsman and Nigel Brown. Manhire explores what Antarctica means to the human psyche, including the ideas of wilderness, purity, exploration, and life and death.

118. Kenneally, Cath. "New New Zealand Fiction". Review of The Picador Book of Contemporary New Zealand Fiction, ed. Fergus Barrowman. Meanjin 55, no. 4 (1996): 704-709.

Discusses "Ponies" and the Wellington setting. Provides the historical context of Gandhi's assassination and references to India. Briefly mentions the title of the story in connection to Antarctica.

119. Lauder, Hugh. "The Poetry of Bill Manhire". Landfall 37, no. 3 (September 1983): 299-309.

Discusses the idea that the source of strength in Manhire's poetry is also the weakness "disrupt[ing] our expectations and disturb[ing] our cosseted sensibilities". Examines the open-ended structure of many of the poems and the creation of tension. Explores in depth "The Song" including angst, the "juxtaposition of the lyrical and the mundane", changes in register, violence, physical contact, the use of "I" and "you", and what the poem is 'about'. Posits that "Manhire is conducting a discussion about the viability of certain key Western cultural archetypes".

Discusses the themes of How to Take Your Clothes Off at the Picnic including the rejection of archetypal images, secure knowledge and communication. Mentions knowledge in relation to "The Collection", "The Calendar" and "The Pickpocket". Comments on the apparent rejection of the "mind-body dichotomy". Examines idea that the volume challenges "the basic assumptions by which we live", the failure of language for adequate communication, and the subsequent failure of relationships. 
Explores the content and structure of the work including tone, title versus poem, imagery and theme, and communication. Examines Good Looks including the themes of mid-life. Mentions "You: A Fragment", "The Voyeur: An Imitation", "Children" and "An Outline" as "meditations on aspects of living" and different in mood and style to the previous collections. Quotes "The Afterlife" as a transition between the two styles and examines the poem at length including the imagination of the reader, re-birth, grief, fantasy and reality.

Discusses the tension in Manhire's work between "creating a space by which we can distance ourselves from the dilemmas of our existence, and confronting them", noting "The Afterlife" and the theme of death against the imagery used. Briefly mentions "The Swallow" and "The Idiot: A Pastoral", and questions their "techniques and preoccupations". Comments on "The Selenologist" and it's "self-contained world".

120. Leggott, Michele. "Joker - Playing Poetry in the Eighties: Manhire, Curnow, Stead, Horrocks". World Literature Written in English 23, no. 1 (Winter 1984): 154-164.

Discusses the idea of jokery, and the "public domain of language". Quotes "Good Looks" and comments on the place of literary criticism in the poem. Briefly mentions the use of literary jokes.

\section{McGregor, Rod. "Poetry and Writing in the Classroom: an Interview with Bill Manhire". English in Aotearoa 33 (September 1997): 54-59.}

Discusses at length the teaching of poetry in the classroom and Manhire's Creative Writing programme. Examines the idea of putting the serious and the comical together in writing in relation to his own poetry. Explores the idea of originality and an audience in writing.

122. McLeod, Rosemary. "The Manhire Mantle". North \& South, no. 107 (February 1995): 72-77.

Explores at length Manhire's childhood and teaching career. Discusses his early reading habits and memories of poetry in school. Mentions his first publishing and editing experiences.

Includes one head and shoulders, and one torso photograph of Manhire. 
123. McQueen, Harvey and Lois Cox. Ten Modern New Zealand Poets. Auckland: Longman, 1974: 188-190.

Provides a brief autobiographical and publishing summary. Describes Manhire's style as "compressed, spare, pared away" and makes connections between this style and thought processes, referring to "The Oreti River", "Growth" and "The Clown at the Death of His Wife". Briefly mentions "The Elaboration" and the "here" of the poem. Comments on the use of understatement, cliché, idiom, and "flat" language, noting "The Proof", "The Clown at the Death of His Wife", "The Pickpocket" and "The Cinema". Examines the use of exaggeration, naming "Pavilion" and "Last Sonnet". Names exceptions to these styles, referring to "The Elaboration", "Threnody", "Gull", and "Declining the Naked Horse".

124. Mane-Wheoki, Jonathan. "Hotere - Out the Black Window". Landfall n.s., 5 no. 2 (November 1997): 233-240.

Review of the exhibition Hotere - Out the Black Window and the accompanying book, Hotere - Out the Black Window: Ralph Hotere's Work with New Zealand Poets. Names poems which Hotere has used in his paintings including Malady, "Pine" the poems from Song Cycle ("The Voyage", "Love Poem", "Wulf", "The Wind"), and Dawn/Water. Mentions the alignment between the work and the poems including the lyricism. Notes the appropriateness of the final line of "Vidyapati's Song" for the exhibition.

125. "Manhire, Bill". In The Oxford Companion to Twentieth Century Literature in English, ed. Jenny Stringer. New York: Oxford University Press, 1996: 430.

Lists works to date. Mentions the use of restraint, minimalism, extremes, uncertainty and humour. Comments on the use of cliché and "a sense that language will always fall short of what the poet is attempting to convey".

126. Marshall, Philippa. "Manhire Wins at Montana". Salient 59, no. 18 (12 August 1996): 8.

Comments on the influence of the creative writing course on his own writing, and the use of "theft". Mention his use of a blurred prose and poetry style.

127. Matheson, Donald. "No Doomed Genius". NZ Education Review 1, no. 18 (30 August 1996): 20.

Discusses Manhire's idea of the poet. Mentions his early writing at primary school.

Notes his decision to write poetry at Otago. 
Includes torso photograph of Manhire.

\section{Moore, Christopher. "Chapter and Verse". Press (Christchurch) (16 October 1999): 12.}

Mentions Manhire's first poem. Discusses the nature of the poet laureateship and the readership for poetry. Comments on What to Call Your Child. Describes Manhire's poetry in general and common topics, noting "marriage, domestic routine, courtship, and children". Explores the idea of the original voice, and its composition of "everything they have ever read or heard or copied". Notes the awareness of writing for an audience. Briefly discusses the process of drafting each poem. Examines "Deep Field Song".

\section{MPJ. "MANHIRE, Bill" in The Oxford Companion to New Zealand Literature, ed. Roger Robinson and Nelson Wattie. Melbourne: Oxford University Press, 1998: 335-336.}

Lists publications to date. Discusses Manhire's variation in register, images, narrative, wit, playfulness and surprise. Describes his poetry as having a "postmodern...consciousness of the strangeness of language", referring to "Jalopy: The End of Love" and the meanings of the word jalopy. Explores "Magasin" and "Out West" and the language used. Discusses Manhire's use of cliché and popular culture, referring to "Princess: The Treatment". Comments on the use of "banalities" and "chit-chat" in "Wellington". Examines the use of the figurative and the literal in "A Death in the Family" and the positioning of the reader in "Wingatui". Briefly discusses "The Swallow".

Describes Manhire's manner as tentative. Lists commonly used images including "moon, water, snow, clouds, stones, wind, birds, trees" and themes such as joy, love, domestic events, relationships, families. Briefly refers to "Song". Mentions the consciousness of being a New Zealander in "Breakfast", "Poem for Vanessa", "Zoetropes" and "Milky Way Bar". Discusses the longer poems in the last decade, particularly "An Amazing Week in New Zealand". Comments on the content and overlap between The Brain of Katherine Mansfield, The New Land: A Picture Book, South Pacific, and Songs of My Life. Mentions The Brain of Katherine Mansfield and the use of the local and genres. Discusses "Cannibals" and its use of the conventions of exploration novels and Boy's Own. Briefly discusses "Some Questions I Am Frequently Asked" and "Wings of Gold: A Week Among Poets". Lists other non-fiction and editorial contributions. 


\section{Murray, Stuart. "“The Muddled Dailiness of Things"”. Review of Doubtful Sounds: Essays and Interviews, by Bill Manhire. New Zealand Books 10 no. 2 (June 2000): 13.}

Mentions the reactions of many commentators and readers of Manhire's poetry. Compares his poetry to that of the American poets, noting the influence of Olson and Creeley, on both Manhire and New Zealand poetry. Comments on the use of games in his poetry, noting "Zoetropes" and isolation. Notes that "Manhire seems happiest and most interested when words are bumping into one another, providing surprises, showing dislocations from the norm". Discusses "Wing of Gold: A Week Among Poets", the use of dirty language, and the possibility of words. Mentions his use of rhythm, the arrangement of words on the page, and the relationship of the words to the poem itself and the world outside. Compares Manhire's background to Irish poet Brendan Kennelly.

\section{Needham, John. "Recent Poetry and Coleridgean Principles". Journal of New Zealand Literature, no. 3 (1985): 35-56.}

Discusses the use of metaphor and image in "The Trees". Briefly explores the use of spareness in "Girl Reading" and the sensory effects this creates. Examines the use of time in "Water, A Stopping Place". Explores the elusiveness of his work, and the extent to which a reader should be given instructions, referring to "The Late Victorian Girl". Discusses the idea of compression and inferences, and the "Coleridgean idea that good poetry makes the reader actively participate in creating the poem".

\section{New Zealand Book Council. "MANHIRE, Bill". \\ http://www.vuw.ac.nz/nzbookcouncil/writers/manhireb.htm [Accessed 19/6/02]}

Provides brief biographical background, including publications, prizes and works he has edited. Mentions the Anglo-Saxon origins of Manhire's earliest pieces. Discusses the use of language and "the apparent arbitrariness with which meanings accrue to signs", noting "Jalopy: The End of Love", "Magasin", and "Out West". Explores the use of clichés, popular culture, and the boundaries between life and art, noting "Princess: The Treatment", "Wellington", and "A Death in the Family". Examines the use of light and shadows in "Wingatui". Compares the techniques used in Keats" "The Swallow" to "On Originality". Discusses tentativeness and the use of images. Comments on the closeness of observation in "Song" and the consciousness of being a New Zealander in "Breakfast". Discusses Manhire's longer poems and the narrative thread, particularly in "An Amazing Week in New Zealand". Mentions "Ventriloquial" and its relation to his verse. Describes "The Brain of Katherine Mansfield". Briefly examines "Cannibals", "Some Questions I Am Frequently Asked", and "Wings of Gold: A Week Among Poets" and their "disenchanted-cum-whimsical-cum-satirical tone". Mentions "Poem for Vanessa", "Zoetropes", "Milky Way Bar", "A Song About the Moon", and "Declining the Naked Horse". 
Includes head and shoulders photograph of Manhire. Also includes book cover shots of The Oxford Companion to New Zealand Literature, Doubtful Sounds, What to Call Your Child, My Sunshine, Songs of My Life, Sheet Music: Poems 1967-1982, Six by Six, Mutes and Earthquakes, Some Other Country, and Collected Poems. Article ends with hypertext links to other pages of interest.

\section{Newton, J. G. H. "“'That's Me Trying to Step Out of that Sentence": An Approach to Some Recent New Zealand Poetry". Master of Arts, University of Canterbury, 1987.}

Contrasts Manhire to "late Baxter or early Wedde and Edmond". Discusses the use of riddles in "The Anglo-Saxon Onion", "Zoetropes" and "Riddle" and the idea of the poem being about the thing it suppresses. Explores the use of proper names and context in "The L \& R song" (comparing it to Wedde's "Victor Charlie"), "Bones" and "Wellington". Examines the first-person "you" and "Night Windows Carey's Bay" noting its original dedication in Islands. Mentions the use of signifier and signified, referring to "Girl Reading", "The Poetry Reading" and "The Voyeur: An Imitation". Explores the "relationship between language and lived experience", examining "An Outline" and "The Swallow". Analyses the demography of "third-person you" and the "'public" structures" used in The Elaboration, How to Take Off Your Clothes at the Picnic and Good Looks. Discusses what the third-person you is substituted with in Good Looks. Examines the preoccupation with family (both parents and children) and compares this to Wedde and Edmond. Mentions Good Looks, "A Death in the Family", "The Spell", "Clouds", "An Outline", "Loosening Up Poem", in relation to father-figures. The parent-child relationship is discussed, mentioning "The Caravan" and "An Outline", and parenthood in "Children" and "Last Things".

Examines the use of the first- and second-person "you" in "Poem for Vanessa" and the use of private and public words. Discusses the use of "I" and "you" in "In the Tent, Elche", "The Incision" and "The Collection". Comments on Manhire's "ambition of scrambling cause and effect" noting "The Collection". In Good Looks, explores the use of "I" distancing the poet, mentioning "The Anglo-Saxon Onion", "Wen", "Vidyapati's Song" and "The Voyeur: An Imitation". Discusses the use of "you" and the third-person you in "The Late Victorian Girl" and "The Afterlife". Explores the use of tense in "The Afterlife", "The Caravan". Mentions "The Breakfast Session", "Breakfast" and "Poem for Vanessa".

134. Newton, John. "The Old Man's Example: Manhire in the Seventies". In Opening the Book: New Essays on New Zealand Writing. Auckland: Auckland University Press, 1995: 162-187.

Examines the "Manhire effect" - a hesitation to subject the poems to analysis, and the limitations of not doing so. Explores Manhire's beginnings noting his first collection is 
predated by Malady and The Old Man's Example. Examines "Love Poem", the emphasis, coupling, and ambiguity. Discusses the idea of "hiddenness" and the meaning of images. Quotes "The Incision", the use of "you", and the "implicit listener" (also used in "Love Poem"). Mentions the influence of Eliot, noting "The Prayer". Quotes Manhire on his use of "you". Discusses at length Manhire's "suppression... of narrative context" in comparison to Wedde and Edmond, noting "Zoetropes" and "Night Windows Carey's Bay". Examines the distribution of "I" and "you" in The Elaboration and How to Take Off Your Clothes at the Picnic, and the use of the pronoun in "Love Poem". Quotes from "The Collection", notes the use of "I" and "we", and compares Manhire's usage to Wedde. Examines his use of language in comparison to Wedde and Edmond, and their use of the pronoun.

Quotes "The Trees", mentioning How to Take Off Your Clothes at the Picnic as the most optimistic of his poetry to date, and Good Looks and the use of the second person. Examines "The Afterlife" and the use of pronoun structure and memory.

Examines Manhire's pessimism, noting Good Looks and "A Song about the Moon". Discusses "The Afterlife", including exhaustion and narrative. Quotes "The Voyeur: An Imitation" and discusses at length the "reader-as-voyeur", in the use of the first and second person. Draws quotes from "Some Questions I Am Frequently Asked" and relates them to his poetry. Examines the use of the radio as a recurring image and the sound it makes in the poems, quoting "The Breakfast Session" and "The Voyeur: An Imitation". Describes the use of "The Masters Voice" in the poems, mentioning "The Distance Between Bodies" and quoting "The Collection". Discusses the topic of mourning in relation to "The Afterlife", "Water, A Stopping Place", "An Outline", "A Death in the Family", and Good Looks in general. Mentions the use of past and future in "The Caravan"

\section{O'Brien, Gregory. "Bill Manhire: Accepting the Naked Horse". In Moments of Invention: Portraits of 21 New Zealand Writers. Auckland: Heinemann Reed, 1988: 100-105.}

Briefly discusses "Declining the Naked Horse". Manhire comments on his use of changes of tone, using "It is Nearly Summer" as an example. Notes the process and inspiration for creating poems. Quotes from "Summer" and makes a short note on the shape of words and their appearance on the page. Discusses common sense in his poems. Examines the theme of childhood, referring to "When You're Dead You Go on 
136. O'Brien, Gregory. Hotere - Out the Black Window: Ralph Hotere's Work with New Zealand Poets. Auckland: Godwit Publishing Ltd, 1997.

Discusses Hotere's first collaboration with Manhire on the Malady paintings. Mentions the "enigmatic quality" of Manhire's work and compares it to Hotere. Quotes Manhire on the creation of Malady, noting the influence of Ian Hamilton Finlay, and the importance of "visual patterning". Comments on other influences including the Russian Suprematists, Italian Futurists and Apollinaire. Mentions Manhire's use of repetition and musicality. Notes the release of Malady to coincide with the Malady paintings exhibition.

Briefly mentions "The birds of ice" as a haiku, and the use of images to convey an emotion. Contrasts the tone of Manhire's poems to the words in Colin McCahon's paintings. Quotes Manhire's explanation of the origins of the Pine works. Mentions the relationship between his "dark elementalism" (reminiscent of "Lorca to Robert Bly") and Hotere's intention. Briefly comments on "Pine" and homesickness, torture, and melancholy.

Discusses Song Cycle and the sensuality of Manhire's lyrics, quoting "Vidyapati's Song". Reprints "The Voyage", "Love Poem", "Wulf", and "The Wind".

Explores the origins of Dawn/Water and the concrete poems with the same title (two versions reprinted). Discusses the use of patterning and minimalism, and links to Tuwhare's "No Ordinary Sun". Briefly mentions Manhire's poetry of the 60's and 70's, and the undercurrent of pain. Comments on "Night Window, Carey's Bay" as a poem about Hotere's house, the Black Window paintings, and its sense of place, both geographical and linguistic.

137. O'Brien, Gregory. "Miserere Mitimiti: a Meeting-Place". PN Review 25, no. 4 (March/April 1999): 26-32. Literature Online, ProQuest.

Discusses the collaboration between Hotere and Manhire. Mentions the Malady paintings, and Hotere's use of Manhire's lyric poems from the 1970's. Briefly mentions Song Cycle. Examines the use of "The Wind", and notes the lack of closure in both the poem and Hotere's work. Comments on the recurring use of "Pine" and the origins of the poem. Briefly mentions "Vidyapati's Song" and "The Voyage".

138. O'Brien, Gregory. "Some Paintings I Am Frequently Asked About: Talking with Bill Manhire about Ralph Hotere”. Landfall n.s., 4, no. 1 (Autumn 1996): 21-33.

Discusses the collaboration between Hotere and Manhire. Considers Hotere's interpretation of Manhire's poetry into art. Mentions the wordplay in Malady and the use of repetition. Notes the use of "The Wind II" in Hotere's Baby Iron paintings, and 
comments that it is unpublished in books form. Discusses "Pine", colonialism, pining, and distance. Mentions the use of poem titles from Good Looks in Hotere's work. Examines darkness in his early poems, and the more playful quality after The Elaboration. Considers the title of Malady. Mentions the creation of the covers for The Elaboration and The Old Man's Example. Discusses the meaning of the words when translated into art, noting Malady. Comments on the lyrical nature and contextualisation of Malady, The Elaboration and Song Cycle. Explores spareness and minimalism in relation to possibilities. Mentions Song Cycle. Notes the interpretation of the Malady paintings as anti-nuclear. Mentions Fault and its origins. Notes allusions to Hotere in "Some Questions I Am Frequently Asked" and the index of The New Land: A Picture Book. Discusses an unpublished piece called "Ralph Hotere at the Intensity Centre".

Reproduces the cover of The Old Man's Example, an image from 'Drawings from Pine, a Poem by Bill Manhire', a photograph of Ralph Hotere, line drawing of "How to Take Off Your Clothes at the Picnic: Drawings for Bill Manhire", and one unnamed line drawing.

139. Peacocke, Heather. "An Accidental Poet". Southland Times (7 October 1998): 27. Also at http://www.arts.uwo.ca/ andrewf/clippings/manhire.htm [Accessed 19/6/02].

Discusses at length Manhire's childhood and his early start in writing. Mentions his Fulbright professorship to Washington, and the content of the courses he will be teaching.

Original includes photograph of Manhire.

\section{Plumb, Vivienne. "Learning to Talk". Planet, no. 12 (Summer 1993): 82-83.}

Interview with Manhire. Discusses growing up in the South Island and the influence of hotel life. Mentions early writing forays and the influence of Grimm's fairytales and Peter Pan. Comments on the process of writing and the creative writing course. Explores the process of generating ideas and the idea of the a distinct voice.

Includes $3 / 4$ photograph of Manhire.

\section{Raffills, Mark. "Words For Wine”. Southern Skies (April 1998): 22-23.}

Interview with Bill Manhire. Discusses the influence of Robert Creeley on his writing. Explains the nature of the Poet Laureateship in New Zealand and the role it involves. Examines Manhire's role in trying to "get rid of the whole self-important, solemnitything in poetry". Comments on the relationship of poetry to the marketplace.

Includes $3 / 4$ photograph of Manhire. 
142. Reid, Nicholas. "Advice to a Man of Letters". Review of Doubtful Sounds: Essays and Interviews, by Bill Manhire. Sunday Star Times (13 February 2000): sec. F, p. 2.

Mentions Manhire's dislike of abstract nouns and adjectives. Disagrees with Manhire's way of looking at poetry. Examines the idea of a "new orthodoxy", approaching big issues "apologetically", using wordplay and humour in order not to seem "elitist". Comments on the criticism of Manhire that "poetry should say something".

143. “Revealing Reading”. Listener 117, no. 2476 (1 August 1987): 59-60.

Writers and critics respond to the question "What books are the best you have ever read, or have influenced you most profoundly?" Bill Manhire comments on King Lear, Peter Pan, Jungle Books, The Magic Faraway Tree, the Icelandic sagas, Penguin Book of New Zealand Verse, the Brothers Grimm, Hans Christian Andersen and the Bible.

144. Riach, Alan. "Baxter \& the Dialect of the Tribe". In Opening the Book: New Essays on New Zealand Writing. Auckland: Auckland University Press, 1995: 105-122.

Contrasts Manhire to Baxter's "rhetorical magniloquence", and as distinct from Allen Curnow. Finds them similar in their use of " 'code-switching' - a practice involving a range of living registers in idiomatic New Zealand English as found in poetry". Quotes Manhire on the practice of poetry, and the use of conversation and voices.

\section{Riach, Alan. "Bill Manhire and Originality". Journal of New Zealand Literature, no. 6 (1988): 225-228.}

Discusses the legacy of New Zealand poetry and Manhire's reaction to it. Explores the use of history, questions and distance in "A Scottish Bride" and looks at the use of the word 'genealogy'. Examines "Love Poem" and compares the use of signatures with "A Scottish Bride". Discusses "On Originality", its tone and its "all-inclusive humility that is brazen beyond coyness". Briefly mentions "Milky Way Bar".

146. Riach, Alan. "New Zealand Poetry from 'Then' til 'Now': 'Wordsworth's Last Stand!'”. British Review of New Zealand Studies, no. 3 (December 1990): 77-86.

Discussion of metonymic poetry. Discusses the use of familiar themes referring to "A Scottish Bride". Mentions histories and the use of questions. Considers the use of the 
word 'genealogy', it's distinction from nostalgia and Foucault's discussion of this. Notes the use of distance and isolation.

\section{Saker, John. "At the Writer's Desk". Wellington City Magazine (October 1985): 82.}

Discusses the use of language in relation to politics and advertising, and the obligation of poets. Mentions his early influences including Walt Whitman and Carl Sandburg. Comments on the evasive quality of his poetry and the differences in writing fiction.

148. Sarti, Antonella. "Bill Manhire". In Spiritcarvers: Interviews with Eighteen Writers from New Zealand, by Antonella Sarti. Amsterdam: Rodopi, 1998: 155-161.

Provides a summary of works and awards up to 1998. Discusses the idea of roots and the colonial perspective. Explores Manhire's idea of history and the relationship between history and imagination. Looks at the concept of nation and landscape, in relation to The New Land: A Picture Book and The Brain of Katherine Mansfield. Examines The Brain of Katherine Mansfield and the ways it deviates from normal pick-a-path books, use of the tourism industry and the sesquicentennial. Discusses the use of subversion in poems and the influences from childhood reading and radio shows. Mentions The New Land: A Picture Book and the use of intertextuality and "surprise and inevitability". Briefly discusses "Synopsis" and "Life with Madame Rosa" and the "fictitiously real". Examines "Songs of My Life", the melodramatic, country-and-western music and clichés. Briefly mentions the relationship between music, rhythm and poetry. Discusses concrete poetry including "Malady" and "The Asterisk Machine". Explores Manhire's view on the relationship between writer and audience, and the readers "power in the transaction". Notes his new book, "An Amazing Week in New Zealand", and a new poem about Sir Edmund Hillary. Comments on the relationship between Manhire's early and recent poetry, including satire and narrative.

149. Sharp, Iain. "MANHIRE, Bill". In The Oxford Companion to TwentiethCentury Poetry, ed. Ian Hamilton. New York: Oxford University Press, 1994: 337-338.

Provides brief autobiographical background. Discusses the use of surprise, and syntax in poems. Mentions Manhire's "high value on both imagination and common sense". Notes influences including Philip Larkin and John Ashbury. Comments on his dislike of jargon and preciousness, use of "lowbrow" material, and his allusions to poets in the English literary tradition. Talks about Malady, including a brief description and his use of word-play. Mentions his humour and lyricism. Lists his themes as those of "ordinary domestic life". Discusses his move into prose fiction mentioning The Brain of Katherine 
Mansfield and The New Land: A Picture Book. Briefly mentions Milky Way Bar and its use of narrative structures.

150. Sharp, Iain. "Bill Manhire". Pacific Wave, no. 106 (June 1997): 46-48.

Discusses the Te Mata Estate New Zealand Poet Laureate Award. Mentions some of the awards he has received and the Creative Writing course. Examines humour in "Wings of Gold: A Week Among Poets". Comments on his childhood and connection to "the bottom half of the South Island". Explains Manhire's start in poetry, and his work in comparison with his contemporaries in the 1960's.

Includes 3 torso and 1 full page head and shoulders photograph of Manhire.

151. Sharp, Iain. "An Interview with Bill Manhire". In In the Same Room, ed. Elizabeth Alley and Mark Williams. Auckland: Auckland University Press, 1992: 15-36. Also at http:/www.nzepc.auckland.ac.nz/authors/manhire/sharp.ptml [Accessed 19/6/02].

Manhire talks at length about his parents, childhood, and the hotel business in the South Island. Discusses his relationship with his contemporaries in the 1960's. Lists writers he read in this period including Robert Creeley, James Wright, Louis Simpson, Robert Bly and Olson. Examines the idea of using your life as a mythology, and his avoidance of this. Explores his relationship with Ralph Hotere, their collaboration on Malady and the Amphedesma Press. Discusses the publication of The Elaboration by Square and Circle. Talks about the influence of Charles Brasch. Mentions Landfall and his first piece published poem.

Examines the shape of the collections, and the chronology versus the order of poems in the books. Comments on his work in anthologising. Briefly discusses literary criticism, and And. Explores the place of imagination in poetry. Examines the use of racing terminology and "Wingatui". Discusses what can happen to New Zealand literature when interpreted overseas. Mentions translations of his works into Russian and Chinese, and his own translation of Old English poems.

Looks at the creative writing programme at Victoria University of Wellington, the "Wellington school", and voice. Explains his switch from poetry to prose in the mid1980's. Mentions the origins of The New Land and The Brain of Katherine Mansfield. Discusses the contrast between Good Looks and Milky Way Bar, mentioning "Hirohito". Comments on his objection to the idea that "I I am a poet, therefore I am wiser than you are"”. Talks about poets whose work he likes including Philip Larkin, John Ashbury and James Fenton. Explores the transition of New Zealand poetry in the 1980's. Discusses the "notion of the line" in Manhire's poetry including the regularity of the three-line 
verse and his way of saying "crazed and illogical things in a very logical, pedantic, grammatical kind of way". Comments on the process of revision. Discusses "The Asterisk Machine", and the Now See Hear! Exhibition. Looks at Manhire's use of technology in creating "Allen Curnow meets Judge Dredd". Discusses his means of "getting started" with poems and "Life With Madame Rosa".

\section{Sharp, Iain. "Triple Bill”. Quote Unquote, no. 34 (April 1996): 11-13.}

Briefly discusses Malady and The Elaboration. Mentions Manhire's use of economy, and language as "whimsical, surreal and mysterious". Discusses his appearance in Ten Modern New Zealand Poets, and the composition of the entry, including three poems not included in any other volumes ("Growth", "Gull", and "Threnody"). Examines his use of juxtaposition and clichés, mentioning "The Pickpocket" and "The Cinema". Looks at his use of humour in "Declining the Naked Horse" and "Pavilion". Discusses the printing of How To Take Off Your Clothes At The Picnic, and the mistake in "Leaving Home". Briefly mentions "The Procedure". Comments that "Picnic is packed with impudent references to the English Department syllabus". Posits that Manhire considers that his way of reading a text is not the only way.

Includes one torso photograph of Manhire.

\section{Smith, Charmian. "Knowledge of Words Key to Writing". Otago Daily Times (2 August 1996): 22.}

Discusses the importance of knowing words and having a respect for language. Briefly mentions the Creative Writing course, the importance of writing with a sense of the reader, and locating each writers 'voice'. Examines the idea that "The language will be part of the process of bringing thoughts into being". Comments on the process of writing. Briefly mentions his role as an anthologist, and the teaching of poetry at high school. Mentions Sam Hunt and poetry as entertainment.

Includes $3 / 4$ photograph of Manhire.

154. Smith, Charmian. "Manhire: a Public Poet". Otago Daily Times (30 November 1999): sec. C, p. 15.

Discusses his Laureateship, and the additional duties he has chosen to undertake during its term. Comments on the composition of "Luck: A Villanelle". Talks about the role that Poet Laureates carry out in Britain, Eastern Europe and America. 
155. Stead, C. K. "From Wystan to Carlos (1979)". In The Penguin History of New" Zealand Literature, ed. Evans, Patrick. Auckland: Penguin, 1990: 242-243.

Briefly questions the theme of "The Old Man's Example". Discusses Manhire's displacement from realism and the literal, "building a word-world with its own codes". Compares and contrasts Manhire to Brian Turner. Identifies Manhire as "a nature poet 'gone wrong'".

156. Stevens, Ross. "Out the Black Window". Salient 60, no. 16 (28 July 1997): 1921.

Comments on "Dawn Water Poem", it's composition, and the addition of "Mururoa" by Hotere to make it political. Briefly mentions the Malady works, and the use of words and puns.

157. Strongman, Luke. "'The Tin Cup Dream': Contextualising Post-Colonialism in the Poetry of Bill Manhire and Ian Wedde". Journal of New Zealand Literature 14 (1996): 127-147.

Describes Manhire as post-colonial and post-modern by their use of voices, realities and ontologies. Characterises him as writing "poetry concerning the act of reading and writing about New Zealand". Touches on the use of irony and the "tongue-in-cheek". Explores his use of nationalism and post-colonialism, time and history. Comments on the relationship between reader and text in The Brain of Katherine Mansfield, and the idea of 'high' and 'low' forms of writing. Posits the idea that his poetry is ahead of currently available literary theory in New Zealand. Examines Manhire, the origin of New Zealand language, and his use of the "conversational" aspects of language. Examines The New Land: A Picture Book and its view of New Zealand. Contrasts Manhire with Wedde, and Manhire's concern with the everyday use of language. Discusses his placing of "New Zealand within a global reference", referring to "Zoetropes". Compares "Magasin" to Wedde's "Odysseus". Comments on Manhire's poetry in relation to literary theory and his seeming rejection of "theorizing". Explores the use of language and its "dirtiness", referring to The Brain of Katherine Mansfield.

Compares and contrasts Wedde's and Manhire's post-colonial characteristics. Likens Manhire's interest in "the 'dirtiness' of language" with Wedde's "interest in 'interconnectedness'”, and compares their ideas of 'centeredness'. Mentions Manhire's voice in Milky Way Bar and the relationship of the poems to the title. Quotes "Zoetropes" and briefly explores the use of language. Comments on "Wingatui" and "Magasin". Discusses in general the development of language in post-colonial cultures. Explores the way in which Zoetropes and Milky Way Bar construct New Zealand culture from the influences of 'outside', and from its isolation. Examines this technique used in reverse in "A Winter Christmas". Comments on the use of signifiers. Mentions the "language of disarmament" in "Out West". Discusses the use of local legend and "Phar 
Lap". Quotes from "Milky Way Bar" and its connection to the "international cultural economy".

\section{Strongman, Luke. "The Trans-Modern Author: Five Contemporary Writers”. Kunapipi 15, no. 3 (1993): 146-161.}

Examines post-modernism and post-colonialism in relation to Walcott, Ondaatje, Manhire, Sealy, and Graham Swift. Discusses the idea of claiming language in order to claim power, and being on the periphery of language, quoting "Milky Way Bar". Briefly mentions the idea of a "galaxy of post-colonial 'conversations' in Manhire's poetry", and the writers' sense of "home". Compares Manhire to Ian Wedde, commenting on their voice, the idea of operating from a "periphery", and nationalism.

\section{Sylge, Carolyn. "A Conversation with Bill Manhire". PN Review 25, no. 3} (January/February 1999): 6-8. Literature Online, ProQuest.

Discusses Manhire's childhood. Mentions "the narrowness of the New Zealand scene" in regards to The Brain of Katherine Mansfield and his other work. Examines Manhire's influences including Robert Creeley, Philip Larkin, John Ashbury, Adrienne Rich, Emily Dickinson. Notes his views on Baxter and Curnow. Describes his poetry as "wideranging", and mentions the relationship of the individual to the world. Discusses his progression as a writer, mentioning his early poems, Milky Way Bar and South Pacific. Comments on "Siena" as postmodern, and the tension between the poem and the poet as wise. Briefly discusses "Wings of Gold: A Week among Poets". Mentions "Magasin", closure, puns and tone, and briefly "Highlights" and closure. Discusses the use of language and not being able to understand a poem "unless it's in your native tongue", quoting "Wingatui" as an example.

160. Wattie, Nelson. "Some Recent Developments in New Zealand Poetry". In Voices from Distant Lands: Poetry in the Commonwealth, ed. Konrad Gross and Wolfgang Klooss. Germany: Konigshausen + Newmann, 1982: 142-152.

Discusses in general the "problem of poetic language". Comments on Manhire, and the New Zealand tendency to "equate the good bloke with the good poet". Explores the idea that Manhire uses a narrow focus, and restricts his topics to New Zealand and his own life. Comments on the contradiction between Manhire's stated audience and his publishing. 
161. Wedde, Ian. "Introduction". In The Penguin Book of New Zealand Verse, ed. Ian Wedde and Harvey McQueen. Auckland: Penguin, 1985: 23-52.

Reprints "Wingatui" and discusses the importance of language and context, mentioning its reprint in The Times Literary Supplement and 'Pseud's Corner'.

\section{Wellington City Gallery. "Hotere". http://www.city-gallery.org.nz/hotere/i.html [Accessed 23/10/02].}

Mentions Hotere's use of Malady, and the composition of the poem. Briefly comments on his use of poetry to put "content" into the work. Notes Hotere's use of "Pine", Dawn/Water and Song Cycle.

163. Wevers, Lydia. "Big Picture, Short Text: New Zealand Short Fiction in the 1990s”. CRNLE Reviews Journal, no. 1 (1993): 49-55.

Discusses "Some Questions I Am Frequently Asked", the "stable subject position", and the representation of the anonymous writer as "A". Explores cultural identity in relation to the story, the debunking of "fixed contexts of authorship", and the use of the speaker. Examines the relationship between short fiction and the portrayal of national and cultural stereotypes. Mentions "South Pacific" and its intertextuality with Janet Frame. Touches on The New Land: A Picture Book and its use of illustrations. Notes "Cannibals" and the use of irony and clichés. Discusses Manhire's versions of "the new land" and the use of subject position. Comments on the use of the index.

\section{Williams, Mark. "Introduction". In The Caxton Press Anthology: New Zealand Poetry 1972-1986, ed. Mark Williams. Christchurch: The Caxton Press, 1987: 13-33.}

Compares Manhire's first appearance in Islands to the poems of others. Comments on Manhire's quote from Pound in The Young New Zealand Poets, and his attitude to "cosmopolitan poetics". Notes Manhire as one who resists the alignment of their poetry to a particular style. Looks at various interpretations of Manhire's work including commentaries by Wedde, Horrocks, Davis and Lauder. Discusses Manhire's attitude to language and representation, and his use of deferred meaning. Mentions his use of language, noting "Magasin" and the use of nostalgia and humour. Comments on "The Pickpocket", the use of "clichés and banalities", and its opposition to the style of Curnow. Examines Manhire's influence on Iain Sharp, and the similar characteristics such as "understatement, linguistic play, the use of mock bullying narrators and the relentless subversion of the romantic cliché". Briefly mentions the influence of Creeley and Beowulf on Manhire, and the use of the local idiom. 
165. Williams, Mark. "Main Currents in Recent New Zealand Literature". Sport, no. 9 (November 1992): 144-157.

Discusses Manhire's break from the "romantic concerns with inspiration and originality to matters of technique and language". Mentions his break from Curnow and focus on the local idiom. Comments on "Magasin". Mentions Manhire's lack of selfconsciousness, and the use of "everyday language".

166. Wright, F. W. Nielsen. The School of Mannerism in Aotearoa: a Polemic. Wellington: Cultural and Political Booklets, 1996.

Reviews Manhire's poetry critically at length. Comments on The Elaboration stating, "All I can say is that the book has almost nothing going for it". Discusses How to Take Off Your Clothes at the Picnic, commenting on lack of variation in style, and use of hypotheticals. Mentions the use of "colloquial phrases". Posits the idea that Manhire imitates in effect Dennis List. Discusses his use of word play and the word "wrist". Briefly mentions Good Looks, mentioning the Anglo-Saxon poems and "Manhire's flat level".

Discusses Zoetropes noting his use of the colloquial idiom. Mentions his use of whimsy and wrists in the collection. Describes his subject matter as "restricted". Comments briefly on his use of rhymed and unrhymed verse. Briefly mentions "The Anglo-Saxon Onion”. Comments on The Old Man's Example (wrongly listed as 1991), comparing some of his poetry to Dennis List. Briefly mentions Milky Way Bar and the writing as "transparent". Comments at length on publication, including suggestion that publication by the University Press of University staff is unethical. Comments on Hoosh, including it's publication, Antarctic subject matter and rhyme. Discusses My Sunshine, mentioning the separate publication of Hoosh and An Amazing Week in New Zealand. Briefly mentions "Isabella Notes", "My Sunshine" and "An American Marriage".

Comments on The Brain of Katherine Mansfield, The New Land: A Picture Book and South Pacific. Comments on the title South Pacific.

167. “The Write Stuff”. Produced by Pinnacle Producing Ltd. Series 1, Programme 17, 10 min. (01:01:28-01:11:06), 1999, Video Recording. (TVNZ Archive, P189761)

Interview with Alison Parr. Discusses the way teaching can speed up the process of learning to write. Explores the idea of inspiration and posits that "inspiration happens when working", rather than before. Comments on words being "part of the process of discovery". Examines the idea of "staying open and ignorant". Briefly discusses found words. Explores the importance of learning to write from reading, and touches on the concept of originality. 


\title{
Manhire on Manhire
}

\author{
168. Manhire, Bill. "Author's Notes" in Collected Poems, by Bill Manhire. \\ Wellington: Victoria University Press, 2001: 289-293.
}

Explains the compilation and ordering of the collection. Discusses the publishing details of The Elaboration, and notes handwritten poems including "The White Pebble" and "A Death in the Family". Reprints the author's statement from The Elaboration. Comments on the publishing details of The Old Man's Example and reprints the "note on the title verso". Notes the distribution of poems, particularly "Buckets", "Wings" and "Sounding the Dark". Discusses the publishing details of How to Take Off Your Clothes at the Picnic, and the error in "Leaving Home". Notes the division of the book into three sections starting with "The Incision", "The Kiss", and "The Song", and reprints the epigraphs.

Examines the publishing and sections of Good Looks, identifying the sections as beginning with "The Breakfast Session", "The Swallow", "Loss of the Forest", "Red Horse", and "An Outline". Notes the combining of "Wingatui" and "Dettifoss" under one title - "Two Landscapes". Briefly notes "The Anglo-Saxon Onion", "Riddle", "Wen" and "Wulf" as "versions of Old English poems". Comments on the publishing of Zoetropes: Poems 1972-1982 and Zoetropes, noting their overlap except for "She Says" and "Breakfast". Notes the publishing details of Milky Way Bar, commenting on the sections beginning with "Out West", "Miscarriage", "Synopsis (Handel's Imeneo)", and three longer poems in section four - "Hirohito", "Brazil", and "Phar Lap".

Discusses the publishing details of My Sunshine, reprinting the epigraph, and noting the different placement of "Hoosh" in Collected Poems. Comments on the publication of What to Call Your Child, and reprints the epigraph. Discusses the origins of "Luck: A Villanelle", "Inesilla", "Grapes", "The Album", and "Colin". Notes the addition of "Between Drinks", "The Gong", "Fist Round a Magnet" and "Nevertheless", and notes their original publication in Black Sheep and Other Poems.

Discusses the bringing together of the Antarctic poems under Antarctic Field Notes, commenting on the first publication of "Hoosh". Notes the first appearance of "The Polar Explorer's Love Song", "Deep Field Song", "Antarctic Stone", and "Visiting Mr Shackleton" in Homelight, and comments on its publication. Briefly notes the commissioning of "The Next Thousand".

Comments on the character of the individual volumes, and comments on the cover of the collection. Lists acknowledgements. 
169. Manhire, Bill. "Bill Manhire" in The Young New Zealand Poets, ed. Arthur Baysting. Auckland: Heinemann Educational Books Ltd, 1973: 122-9.

Briefly mentions publications to date. Offers an image of the creative process. Discusses his current writing technique and the use of the "shorter lyric". Explores the idea of working from a particular time and place, referring to Pound.

170. Manhire, Bill. "Breaking the Line: A View of American and New Zealand Poetry". Islands n.s., 3 no. 2 (December 1987): 142-154.

Notes reading R. A. K. Mason's poems "with enthusiasm" during his adolescence, and the influence of Walt Whitman. Argues that New Zealand had to escape from Mason's "sense of tradition" in order to begin producing poetry. Quotes from Pablo Neruda regarding the idea of bad taste and decorum in poetry. Discusses the readers active role and contribution to the construction of the poem's meaning. Compares Baxter's and his poetry as having these qualities and discusses his own use of the word "you".

Mentions early reading. Comments on the "gap" between what he studied at University, and his home life. Quotes the Introduction to Contemporary American Poetry (1962) and it's influence on him. Mentions the poets that he tried to write like, and the influence of Robert Creeley, quoting "The Proposition" as "one of my Robert Creeley poems". Also quotes "The Cinema" against Louis Simpson. Discusses the influence of American poetry and it's context in other American influences (including movies and music). Posits that the value of American poetry is its diversity.

Compares his poetry to that of Brunton, Hunt and Wedde and notes the differences. Mentions the idea of the "voice" and his voice as a composition of others. Discusses the idea of the artist: "The work of art is composed out of used and second-hand items; yet the finished piece is 'new' and 'original', however old and derivative its parts". Names "The Cinema" in relation to this idea and its composition from English idioms.

Comments on his poetry as moving between drama and comedy, including "tonal drifts and lurches". Notes the idea of the authentic voice, quoting "On Originality".

171. Manhire, Bill. "Dirty Silence: Impure Sounds in New Zealand Poetry". Australian and New Zealand Studies in Canada, no. 4 (Fall 1990): 57-71. Also in Doubtful Sounds: Essays and Interviews, by Bill Manhire. Wellington: Victoria University Press, 2000: 9-22. Also in Dirty Silence: Aspects of Language and Literature in New Zealand, ed. Graham McGregor and Mark Williams. Auckland: Oxford University Press, 1991.

Argues in favour of "dirty language". Discusses the origins and possible range of meanings of his name. Comments on poetry's drive toward "purity", noting Shelley, and the influence of politics and advertising. Discusses the idea of contaminated language, and conversely that "purity may become a pleasant name for uniformity". Quotes 
"Hotere" by Tuwhare, and the multiple voices as a way of avoiding homogeneity. Discusses the use of code-shifting and multiple languages, registers, tones and dialects. Mentions the voices of "Magasin" and the end joke which uses code-switching. Examines "Phar Lap" and the "range of meanings which attach to the name".

172. Manhire, Bill. "Early Reading: The Magic Faraway Tree". Education 26, no. 10 (1977): n.p. Also in Doubtful Sounds: Essays and Interviews, by Bill Manhire. Wellington: Victoria University Press, 2000: 55-56.

Discusses his early reading, including comics and Enid Blyton. Names The Magic Faraway Tree as particularly special, including a synopsis. Notes Blyton's strength as "the way she overrides... our habitual distinctions between what is real and what is fantastic".

173. Manhire, Bill. "Introduction". In Mutes and Earthquakes: Bill Manhire's Creative Writing Course at Victoria, ed. Bill Manhire. Wellington: Victoria University Press, 1997: 9-21.

Discusses the use of exercises in writing. Talks about the concept of writers writing about things that they don't know and the use of constraints to inspire inventiveness. Examines the concept of the writers voice.

174. Manhire, Bill. "A Poet at the Pole". Across the Pacific 8 no. 1 (Spring 1999): n.p. Also in Doubtful Sounds: Essays and Interviews, by Bill Manhire. Wellington: Victoria University Press, 2000: 243-245

Comments on the affection of the scientists for their projects, and the connection to the subject of "Deep Field Song". Mentions the geographic location in which the poem is based.

175. Manhire, Bill. "The Poetry File: Charm". Quote Unquote, no. 8 (January/February 1994): 13.

Reprints "Wen". Examines it as "a loose translation of an Anglo-Saxon charm". Discusses other Old English charms and the idea that language can "intervene magically in the world". Mentions the structure of charms and the use of commands, and change.

Includes head and shoulders photograph of Manhire. 
176. Manhire, Bill. "The Poetry File: Concentration". Quote Unquote, no. 3 (August 1993): 11.

Discusses the definition of poetry, and the way text is arranged on the page. Explores the way in which a poetry "can condense vast amounts of meanings into a small space". Examines the use of ambiguity to do this, and the creation of new words.

177. Manhire, Bill. "The Poetry File: Lists". Quote Unquote, no. 15 (September 1994): 10.

Discusses the use of lists in poetry, noting it's ability to reach a climax because of accumulation, and "anti-hierarchical" nature. Quotes "Declining the Naked Horse" and the idea that "Sometimes lists quickly wear out their welcome".

Includes head and shoulders photograph of Manhire.

178. Manhire, Bill. “The Poetry File: Uselessness”. Quote Unquote, no. 20 (February 1995): 11.

Discusses the role of the poet, and explores the idea "that poetry can intervene in the public world in significant and efficacious ways". Mentions language as the division between the human and animal world. Comments on the role of poetry with the meaning of words. Discusses the place of poetry in the economy.

Includes head and shoulders photograph of Manhire.

179. Manhire, Bill. "Stranger at the Ranchslider". Journal of New Zealand Literature, no. 13 (1995): 11-22. Also in Doubtful Sounds: Essays and Interviews, by Bill Manhire. Wellington: Victoria University Press, 2000: 199208.

Mentions Manhire's early listening, including The Goon Show, Peter Sellers and Beyond the Fringe. Discusses his relationship with Baxter, and the reasons that he was "temperamentally at odds" with him.

180. Manhire, Bill. “Tribal Voices”. Listener 169 no. 3085 (26 June 1999): 42-44.

Gives a background to poet laureates in Britain and the US. Discusses his Te Mata laureateship and the expectations and provisions of the post. Discusses the creation of the poem "Luck: A Villanelle". 
Appendix A: References for relevant items which have not been sighted.

181. "Bill Manhire Competition on Sunday Edition". N.p., 28 min., n.y., Sound Recording. (Sound Archives, T7921)

"Alison Parr talks to Bill Manhire".

182. "Concert FM - Talking of Poets". Produced by Elizabeth Alley, 170 min, n.y., Sound Recording. (Sound Archives, DAT225)

"Poets talking about themselves and reciting some of their poetry". Includes Manhire.

183. “Concert Programme - The Poet's Voice”. N.p., 105 min., n.y., Sound Recording. (Sound Archives, VC12)

"New Zealand poets introduce and read a selection of their recent works". Includes Manhire.

184. Phillipson, Allan Robert. "C. K. Stead and Three Modes of New Zealand Poetry (Stead, C. K. )”. PhD, University of British Columbia, 1997. OCLC Firstsearch/AAGNQ25137.

"My conclusion suggests that [the] post-purist approach applies not only to the work of C. K. Stead, but also to some of the recent work by other New Zealand poets, such as Allen Curnow, Bill Manhire and Ian Wedde". 


\section{Appendix B: Abbreviations}

Non-standard abbreviations used:

n.p. $\quad$ No producer listed

n.y. $\quad$ No year listed

TVNZ Television New Zealand 


\section{Appendix C - Bibliography to the Introduction}

Berendse, Sabine. "Gay and Lesbian Characters and Themes in New Zealand Novels from 1947-1998". Master of Library and Information Studies, Victoria University of Wellington, 1999.

Burns, James Alexander Scott. A Century of New Zealand Novels. Auckland: Whitcombe \& Tombs, 1961.

Chapple, L. J. B. A Bibliographical Brochure Containing Addenda and Corrigenda to Extant Bibliographies of N.Z. Literature. Wellington: A. H. and A. W. Reed, 1938.

Crane, Ralph C. Ending the Silences: Critical Essays on the Works of Maurice Shadbolt. Auckland: Hodder Moa Beckett, 1995.

Krummel, D. W. Bibliographies: Their Aims and Methods. London: Mansell Publishing Limited, 1990.

Loversidge, Avril. "A Select Bibliography of Writings about Jack Body and his Compositions between 1965 and 2000". Master of Library and Information Studies, Victoria University of Wellington, 2000.

McQueen, Harvey, and Lois Cox. Ten Modern New Zealand Poets. Auckland: Longman, 1974.

New Zealand Book Council. MANHIRE, Bill. http:/www.vuw.ac.nz/nzbookcouncil/writers/manhireb.htm [Accessed 19 June 2002] 
Park, Iris M. New Zealand Periodicals of Literary Interest. Wellington: National Library Service, 1962.

Robinson, A. M. Lewin. Systematic Bibliography: A Practical Guide to the Work of Compilation. London: Clive Bingley, 1979.

Sargent, Lyman Tower. New Zealand Utopian Literature: An Annotated Bibliography. Wellington: Stout Research Centre, 1997.

Sarti, Antonella. Spiritcarvers: Interviews with Eighteen Writers from New Zealand. Amsterdam: Rodopi, 1998.

The University of Auckland Library: Te Tumu Herenga. Bill Manhire.

http:/www2.auckland.ac.nz/lbr/nzp/nzlit2/manhire.htm [Accessed 14 July 2002] 


\section{First Line Index}

\section{First line}

A big pile of sparkle

A boy getting pleasure. .

A friend thinks he knows best.

A little is too little, passion

A metal road right through

A rubber duck is paddling up the sky

A starting. Words which begin

A whole row of bibles.

A woman commits suicide

After a time of drought, the whole heart dances.

All day at the lake we watched

All day I stack cans.....

All day shovelling small snow

All night Brazil approached you through the dark.

Always myself though

An uneventful day. When his mother had

And again I stand by Bryn's

Another hut filled with food

Antarctica!

As you will know

Athletic Park, April 1959.

Barques we ride on over the se

Between the cough and the howl

But my little Iroquois is shy.

But who can feel sadness.

Cold like the cold southern ocean.....

Cold spring morning..

Cool! Wow! Beautiful! Awesome!

Damp white eggs

Dawn/Water

Disguised as women we at last drop anchor.....

Do you drive an old car?

Each time I sneeze..

Early morning, there's

Enormous purple dawns, the water

Even the children lend a hand
Poem title

Book title

Recovered Noah............................................. What To Call Your Child, Collected Poems

The Late Victorian Girl ...................................... Good Looks, Zoetropes: Poems 1972-82, Sheet Music: Poems 1967-1982, Collected Poems

The Coast............................................... How To Take Off Your Clothes at the Picnic, Zoetropes: Poems 1972-82, Sheet Music: Poems 1967-1982, Collected Poems

Petal........

It is Nearly Summer

Zoetropes.

Early Days in the Colony

Buckets.

Luck: A Villanelle...

The Collection.......

Flood.........

The Prairie Poet

Brazil..

The Voyage.

Fist Round a Magne

An Extended Family

Current

Evans..

Some Frames

What it Means to be Naked.

An Amazing Week in New Zealand

The Trees.

Between the Cough and the Howl.

Goodbye..

Grapes

Magpie Crooning

The Buried Soap.

Breakfast.

Dawn/Water

Synopsis (Handel's Imeneo )

Jalopy: The End of Love.

The Spell

Beach Life.

. The Afterlife...

Breaking the Habit.
How To Take Off Your Clothes at the Picnic, Zoetropes: Poems 1972-82, Sheet Music: Poems 1967-1982, Collected Poems Zoetropes, Zoetropes: Poems 1972-82, Sheet Music: Poems 1967-1982, Collected Poems

Milky Way Bar, Collected Poems

The Old Man's Example, Sheet Music: Poems 1967-1982, Collected Poem

What To Call Your Child, Collected Poems

How To Take Off Your Clothes at the Picnic, Sheet Music: Poems 1967-1982, Collected Poems

How To Take Off Your Clothes at the Picnic, Zoetropes: Poems 1972-82, Sheet Music: Poems 1967-1982, Collected Poems

My Sunshine, Collected Poems

Milky Way Bar, Collected Poems

The Elaboration, Zoetropes: Poems 1972-82, Sheet Music: Poems 1967-1982, Collected Poems

Collected Poems (attributed to What To Call Your Child)

Milky Way Bar, Collected Poems

What To Call Your Child, Collected Poems

What To Call Your Child, Collected Poems

What To Call Your Child, Collected Poems

Good Looks, Zoetropes: Poems 1972-82, Sheet Music: Poems 1967-1982, Collected Poems

. An Amazing Week in New Zealand, My Sunshine, Collected Poems

How To Take Off Your Clothes at the Picnic, Zoetropes: Poems 1972-82, Sheet Music: Poems 1967-1982, Collected Poems

My Sunshine, Collected Poems

What To Call Your Child, Collected Poems

What To Call Your Child, Collected Poens

My Sunshine, Collected Poems

Good Looks, Zoetropes: Poems 1972-82, Sheet Music: Poems 1967-1982, Collected Poems

Homelight: An Antarctic Miscellany, What To Call Your Child, Collected Poems

Good Looks, Sheet Music: Poems 1967-1982, Collected Poems

Dawn/Water

Milky Way Bar, Collected Poems

Milky Way Bar, Collected Poems

The Elaboration, Zoetropes: Poems 1972-82, Sheet Music: Poems 1967-1982, Collected Poems
My Sunshine, Collected Poens 


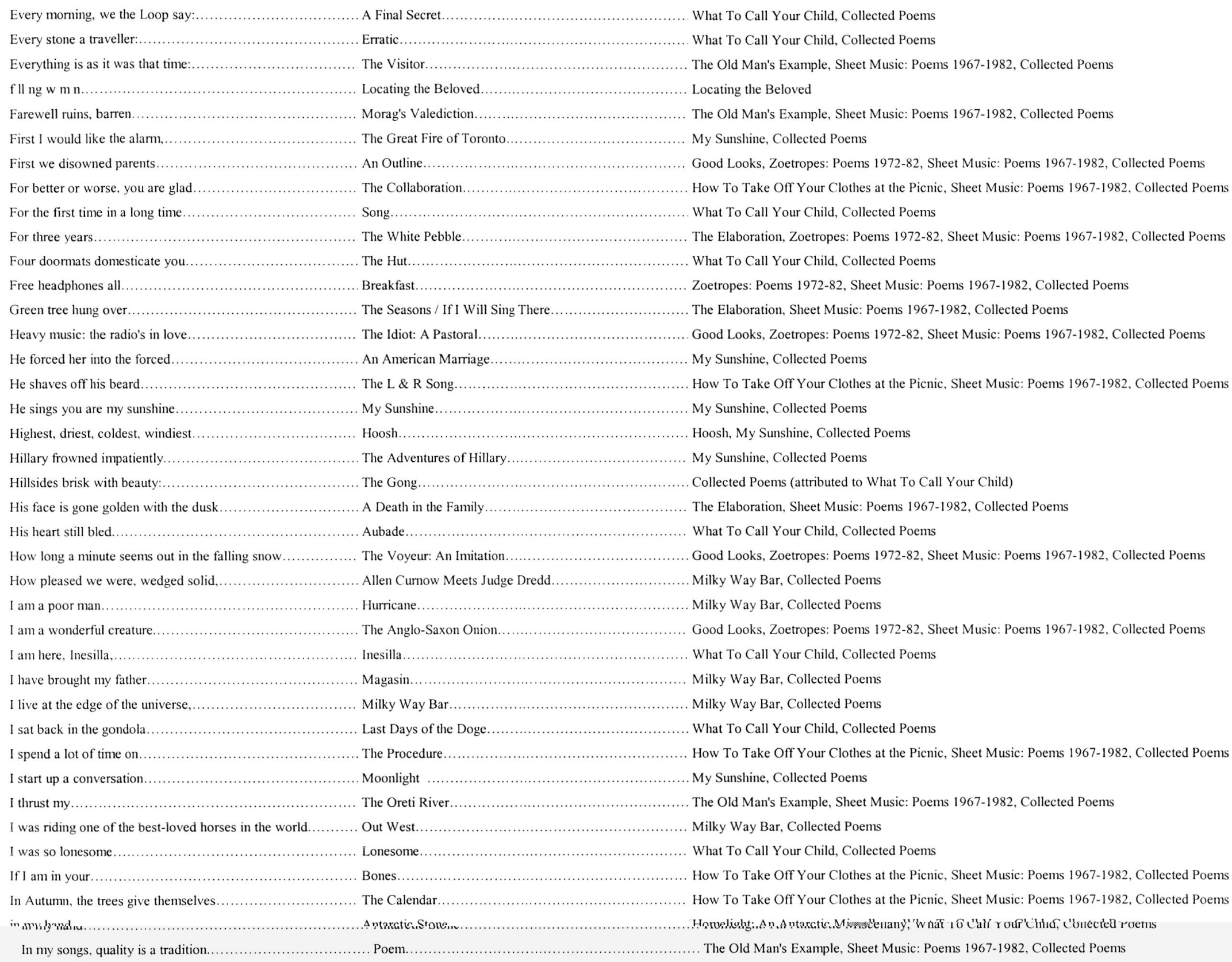


In the distance, the rookery's

Adélie

In the half light of the Early Settlers Museum.

In the month of wind the bones.

In the year most of the girls

In this way we came to the place of sacrifice.....

Innumerable worlds! We dream of them......

Is gazing at the moon again.

Isabel sits in her study

It is hardly sensuous, but having

It is so white.

It is the pitchy night. She has.

It was nothing like a legacy.

It's a large town..

It's about time I was on time, late

It's lonely in the world..

John Keats

Kaikoura, Bluff, the Haast

Let's just reject..

Like a dwelling......

Listen Nigel, I'll eat dogs if I have to

Long division and underprivilege,

Loosen up chum. The ocean.

Love is a fact.

Lovers, the bodies one by another,

malady.

Mary, Mary, quite to the contrary

McCahon said jump..

Men are singing by the willows.

Mike returns from filming the wind

Moths have chased you out

Mountains come close.

Mountains in boxes,

$\mathrm{Mr}$ Sharp gets out of the taxi.

Music beats sticks.......

Music is this task you undertake

My body as an act of derision,

'My lost youth

My lover's limbs are placed

My mother was teaching Polish soldiers
Picnic at Woodhaugh.

wo Songs for Morag

Miscarriage.

Americ

Contemplation of the Heaven

The Selenologist

Isabella Note

How To Take Off Your Clothes at the Picnic

Summer...

A Hope for Frank and Anne

Legacies.

Wellington

The Mutability Cantos

Party Going.

The Swallow

South Island Companion.

The Importance of Personal Relationships

Riddle.

. 'Listen Nigel'.

A Scottish Bride.

Loosening up Poen

Loss of the Forest

The Dream

Malady

Devotion...

Colin.

The Snow.

Time Lapse.

Wintrous.

Now You See It

Remarkables.

Colloquial Europe.

Moonlight Gossip. .

The Caravan.

The Song

My Lost Youth.

dyapati's Song.......

The English Teacher
What To Call Your Child, Collected Poems

What To Call Your Child, Collected Poems

The Elaboration, Sheet Music: Poems 1967-1982, Collected Poems

Milky Way Bar, Collected Poems

What To Call Your Child, Collected Poems

How To Take Off Your Clothes at the Picnic, Zoetropes: Poems 1972-82, Sheet Music: Poems 1967-1982, Collected Poems Good Looks, Zoetropes: Poems 1972-82, Sheet Music: Poems 1967-1982, Collected Poems

My Sunshine, Collected Poems

How To Take Off Your Clothes at the Picnic, Zoetropes: Poems 1972-82, Sheet Music: Poems 1967-1982, Collected Poems 作 The Elaboration, Sheet Music: Poems 1967-1982, Collected Poems

Zoetropes, Zoetropes: Poems 1972-82, Sheet Music: Poems 1967-1982, Collected Poems Good Looks, Zoetropes: Poems 1972-82, Sheet Music: Poems 1967-1982, Collected Poems How To Take Off Your Clothes at the Picnic, Zoetropes: Poems 1972-82, Sheet Music: Poems 1967-1982, Collected Poems Good Looks, Zoetropes: Poems 1972-82, Sheet Music: Poems 1967-1982, Collected Poems Good Looks, Zoetropes: Poems 1972-82, Sheet Music: Poems 1967-1982, Collected Poems Milky Way Bar, Collected Poems

How To Take Off Your Clothes at the Picnic, Zoetropes: Poems 1972-82, Sheet Music: Poems 1967-1982, Collected Poems Good Looks, Zoetropes: Poems 1972-82, Sheet Music: Poems 1967-1982, Collected Poems

What To Call Your Child, Southern Convergence, Collected Poems

Zoetropes, Zoetropes: Poems 1972-82, Sheet Music: Poems 1967-1982, Collected Poems Good Looks, Zoetropes: Poems 1972-82, Sheet Music: Poems 1967-1982, Collected Poems Good Looks, Zoetropes: Poems 1972-82, Sheet Music: Poems 1967-1982, Collected Poems How To Take Off Your Clothes at the Picnic, Sheet Music: Poems 1967-1982, Collected Poems Malady

How To Take Off Your Clothes at the Picnic, Sheet Music: Poems 1967-1982, Collected Poems What To Call Your Child, Collected Poems

How To Take Off Your Clothes at the Picnic, Sheet Music: Poems 1967-1982, Collected Poems What To Call Your Child, Collected Poems

How To Take Off Your Clothes at the Picnic, Sheet Music: Poems 1967-1982, Collected Poems What To Call Your Child, Collected Poems

My Sunshine, Collected Poems

My Sunshine, Collected Poems

Good Looks, Sheet Music: Poems 1967-1982. Collected Poem

Good Looks, Zoetropes: Poems 1972-82, Sheet Music: Poems 1967-1982, Collected Poems

Tow To Take Off Your Clothes at the Picnic, Zoetropes: Poems 1972-82, Sheet Music: Poems 1967-1982, Collected Poem

Milky Way Bar, Collected Poems

Good Looks, Sheet Music: Poems 1967-1982, Collected Poems 
Names for paint,

Now I am feeling grief

Oh it is serious and it changes

Oh star, you are wounded,..

On one trip he brought home.

On the road between Aye and Och Aye

On the wall a tapestry......

Our flat's attacked by tinsel. It steals

Palace scene in downtown L.A....

Patch me out to Lake Bomey

Poets, I want to follow them all.,........

Poor boy. Here he is,

Poor boy, poor boy.

Rainy days inside

Rest, preening, stretchin

Right ten degrees rudde

Rusty glacier snout:

Say goodbye to the penguins,.

She did not speak to me yesterday....

She had what people are given to dscibe as hery.

She is even gone now

She lived there once where you were once...

She lives behind the waterfall.

She overhears the sound of things in hiding....

She really was drawing! And it was....

She threw him the tea-towel.

She wants to fly.

She was a chaste gir

Sheets on the floor, a stick

Since I need something else....

Sit in the car with the headlights off

Sky and water, quiet.

Snow in the brain, under the skin.

Snow that is late arriving

Someone leaves Paradise Los

Sometimes you are distinctly

Somewhere all the wrong reaso

Song of the flute, the river's

Talking to you, Chinese poetry
Between Drinks.

The Clown at the Death of His Wife...

Pledge....

Poem Against the Natural World

Our Father...

Ain Folks

Going Outside..

A Winter Christmas

Some Screens

Deep Field Song

On Originality

Masturbating

eaving Home

City Life.

Displays.

Into the Ice Shelf

Blood Falls. .

Goodbye.

The Proof....

Jenny's Bicycle.

Watching Alison in Winter

Princess: The Treatme

Girl Reading

In the Studio

Domestic.

Poem for Vaness

Red Dream.

The Distance Between Bodics...

In the Tent, Elche.

Two Landscapes (Wingatui)

Opoutere Nest Song

The Incision.

Two Landscapes (Dettifoss)

Milton

The Contract.

The Occupation, Against Time

Landscape with Bride.

Poetics.
Collected Poems (attributed to What To Call Your Child)

The Old Man's Example, Sheet Music: Poems 1967-1982, Collected Poems

Whall Your Child, Collected Poems

Good Looks, Sheet Music: Poems 1967-1982, Collected Poem

Milky Way Bar, Collected Poems

My Sunshine, Collected Poems

What To Call Your Child, Collected Poems

Milky Way Bar, Collected Poems

My Sunshine, Collected Poems

Homelight: An Antarctic Miscellany, What To Call Your Child, Collected Poens

How To Take Off Your Clothes at the Picnic, Zoetropes: Poems 1972-82, Sheet Music: Poems 1967-1982, Collected Poems

Milky Way Bar, Collected Poems

How To Take Off Your Clothes at the Picnic, Sheet Music: Poems 1967-1982. Collected Poems

How To Take Off Your Clothes at the Picnic, Zoetropes: Poems 1972-82, Sheet Music: Poems 1967-1982, Collected Poems

What To Call Your Child, Collected Poems

What To Call Your Child, Collected Poems

What To Call Your Child, Collected Poems

What To Call Your Child. Collected Poems

The Elaboration, Sheet Music: Poems 1967-1982, Collected Poems

The Old Man's Example

The Elaboration, Sheet Music: Poems 1967-1982, Collected Poems

(1967-1982, Collected Poems

Milky Way Bar, Collected Poems

Zoetropes, Zoetropes: Poenss 1972-82, Sheet Music: Poems 1967-1982, Collected Poems

My Sunshine, Collected Poems

What To Call Your Child, Collected Poems

Good Looks, Zoetropes: Poems 1972-82, Sheet Music: Poems 1967-1982, Collected Poems

My Sunshine, Collected Poems

Zoctopes, Zoetropes: Poems 1972-82, Shect Music: Poems 1967-1982, Collected Poens

The Elaboration, Zoetropes: Poems 1972-82, Sheet Music: Poems 1967-1982, Collected Poems

Good Looks, Zoetropes: Poems 1972-82, Sheet Music: Poems 1967-1982, Collected Poems

My Sunshine, Collected Poems

How To Take Off Your Clothes at the Picnic, Zoetropes: Poems 1972-82, Sheet Music: Poems 1967-1982, Collected Poems

Good Looks, Sheet Music: Poems 1967-1982, Collected Poem

Milky Way Bar, Collected Poems

How To Take Off Your Clothes at the Picnic, Sheet Music: Poems 1967-1982, Collected Poem

The Elaboration, Sheet Music: Poems 1967-1982, Collected Poems

What To Call Your Child, Collected Poem 
Tenacious cries that shak

Thank you for listening so patienty...

Thank you, she said, we'll stick.

The Americans make many spectacular movies:.

The big chicks chase any adult

The big stage and golden curtain

The breath still in me,

The damp sky is eating your hair....

The dark lift of the lungs

The goddess Hypotherm

The green fields. The green field

The helicopter delivers us down......

The highly prized photograph of the paperweigh

The house was in the mountains .....

The kids want to grow up..

The light touching the concrete is the light I like, I

The likelihood is.

The little primus is off,.

The moon casts our shadows

The moon lives by damaging the ocean

The naked horse came into the roon

The plastic bags. .

The red crayon makes us ...

The rose can't hurt itself.

The skua alights among the penguin

the week it

There are places named for

There is a story that tells

There is no question.

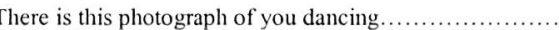

There must be some remedy for ar...

there was a way out of here

There was a young fellow called Single

There'll be the same non-stop palaver....

These drifting leaves, for instance.....

They take it from me:

This is our dying season

This lantern was designed.....
The Friends

Valedictory

Factory

The Cinema

Food Chain....

Doctor Zhivago

Riddle.

The Kiss.

Petenera.

Making History......

The Polar Explorer's Love So

The Poetry Reading

Cape Royds.

The Paperweight.

Pavilion ....

Last Thing

Landscape with Pines.

Children

Blue Flower..

The River

A Song about the Moon

Declining the Naked Hors

Onlookers: A Story

Red Horse.

Nevertheless.

Scavenger

The Proposition.

Water, A Stopping Place

The Missing Children.

Love Poem. .

You: A Fragment

The Elaboration.

Mukluk Limerick

The Next Thousand

The Old Man's Example....

Wulf..

For President Johnson on the Shores of America

Wings
How To Take Off Your Clothes at the Picnic, Sheet Music: Poems 1967-1982, Collected Poems

What To Call Your Child, Collected Poems

Milky Way Bar, Collected Poems

How To Take Off Your Clothes at the Picnic, Zoetropes: Poems 1972-82, Sheet Music: Poems 1967-1982, Collected Poems What To Call Your Child, Southern Convergence, Collected Poems

My Sunshine, Collected Poems

What To Call Your Child, Collected Poems

1972-82. Sheet Music: Poems 1967-1982. Collected Poems What To Call Your Child, Collected Poems

Good Looks, Sheet Music: Poems 1967-1982, Collected Poems

Homelight: An Antarctic Miscellany, What To Call Your Child, Collected Poems

. How To Take Off Your Clothes at the Picnic, Zoetropes: Poems 1972-82, Sheet Music: Poems 1967-1982, Collected Poems What To Call Your Child, Collected Poems

How To Take Off Your Clothes at the Picnic, Zoetropes: Poems 1972-82, Sheet Music: Poems 1967-1982. Collected Poems The Elaboration, Zoetropes: Poems 1972-82, Sheet Music: Poems 1967-1982, Collected Poenıs

Good Looks, Zoetropes: Poems 1972-82, Sheet Music: Poems 1967-1982, Collected Poems

What To Call Your Child, Collected Poems

Good Looks, Zoetropes: Poems 1972-82, Sheet Music: Poems 1967-1982, Collected Poems

What To Call Your Child, Collected Poems

The Elaboration, Sheet Music: Poems 1967-1982, Collected Poen

Good Looks, Zoetropes: Poems 1972-82, Sheet Music: Poems 1967-1982, Collected Poems

Good Looks, Zoetropes: Poems 1972-82, Sheet Music: Poems 1967-1982, Collected Poems

Milky Way Bar, Collected Poems

Good Looks, Zoetropes: Poems 1972-82, Sheet Music: Poems 1967-1982, Collected Poems

Collected Poems (attributed to What To Call Your Child)

What To Call Your Child, Southern Convergence, Collected Poems

How To Take Off Your Clothes at the Picnic, Zoetropes: Poems 1972-82, Sheet Music: Poems 1967-1982, Collected Poems Zoetropes, Zoetropes: Poems 1972-82, Sheet Music: Poems 1967-1982, Collected Poems

My Sunshine, Collected Poems

The Elaboration, Zoetropes: Poems 1972-82, Sheet Music: Poems 1967-1982, Collected Poems

How To Take Off Your Clothes at the Picnic, Zoetropes: Poems 1972-82, Sheet Music: Poems 1967-1982, Collected Poems

Good Looks, Zoetropes: Poems 1972-82, Sheet Music: Poems 1967-1982. Collected Poems

The Elaboration, Zoetropes: Poems 1972-82, Sheet Music: Poems 1967-1982, Collected Poems

Homelight: An Antarctic Miscellany

Collected Poems

The Old Man's Example, Sheet Music: Poems 1967-1982, Collected Poem

Good Looks, Zoetropes: Poems 1972-82, Sheet Music: Poems 1967-1982, Collected Poems

The Old Man's Example, Sheet Music: Poems 1967-1982, Collected Poems 
This pick still works

Time is months and your mother's promise

Toby lying on the floor

To improve his eyesight

To know his place on earth

Under an eyelash..

Unlikely combinations,

Veronica's heart belongs to her....

Walking down Princes Street

Water seeps through

Water: you surface by multiplying

Weary, stale, flat, unprofitable.

We get on well together

We talk and talk till silence interrupts.

Wen, wen, little wen.

What can you gain from my name?

What do you take

When there's moonlight

When we touch,.

When you make.

White inside the weather

Words touch the tongue

You go by coral and by sands

You never could resist.

You want to sing, halfway.....

You write a long poem.

Your absence is a hurt....
Outside the Hut.

Clouds

When You're Dead You Go on Television.....

Hirohito.

Sounding the Dark.

.. Millennial

. Phar Lap.

What to Call Your Child

The God Who Watches Over All Perhaps

Your Room.

Ornaments...

Some Epithets...

The Pickpocket.

Good Looks.

The Album.

The Prayer. .

Vanessa's Song.

Poem.

The Directory

Forecast.

Agitated Nation

Turtle

Life with Madame Ros

The Breakfast Session

Night Windows Carey's Bay

Your Absence.
What To Call Your Child, Collected Poems

How To Take Off Your Clothes at the Picnic, Zoetropes: Poems 1972-82, Sheet Music: Poems 1967-1982, Collected Poems

(1972-82, Sheet Music: Poems 1967-1982, Collected Poems

Milky Way Bar, Collected Poems

Collected Poems (attributed to The Old Man's Example)

What To Call Your Child, Collected Poems

Milky Way Bar, Collected Poems

What To Call Your Child, Collected Poems

The Old Man's Example, Sheet Music: Poems 1967-1982, Collected Poems

The Old Man's Example, Sheet Music: Poems 1967-1982, Collected Poems

How To Take Off Your Clothes at the Picnic, Zoetropes: Poems 1972-82, Sheet Music: Poems 1967-1982, Collected Poem How To Take Off Your Clothes at the Picnic, Good Looks, Zoetropes: Poems 1972-82, Sheet Music: Poems 1967-1982, Collected Poems

How To Take Off Your Clothes at the Picnic, Zoetropes: Poems 1972-82, Sheet Music: Poems 1967-1982, Collected Poems Good Looks, Zoetropes: Poems 1972-82, Sheet Music: Poems 1967-1982, Collected Poems

Good Looks, Sheet Music: Poems 1967-1982, Collected Poems

What To Call Your Child, Collected Poems

The Elaboration, Zoetropes: Poems 1972-82, Sheet Music: Poems 1967-1982, Collected Poems

Good Looks, Zoetropes: Poems 1972-82, Sheet Music: Poems 1967-1982, Collected Poems

The Elaboration, Zoetropes: Poems 1972-82, Sheet Music: Poems 1967-1982, Collected Poems

How To Take Off Your Clothes at the Picnic, Sheet Music: Poems 1967-1982. Collected Poems

What To Call Your Child, Collected Poems

Milky Way Bar, Collected Poems

How To Take Off Your Clothes at the Picnic, Sheet Music: Poems 1967-1982, Collected Poems

Milky Way Bar, Collected Poems

Good Looks, Zoetropes: Poems 1972-82, Sheet Music: Poems 1967-1982, Collected Poems

Good Looks, Sheet Music: Poems 1967-1982, Collected Poems

The Elaboration, Sheet Music: Poems 1967-1982, Collected Poems 


\section{Poem Title Index}

Poem title

Book title

A Death in the Family.

The Elaboration, Sheet Music: Poems 1967-1982, Collected Poems

A Final Secret.

What to Call Your Child, Collected Poems

A Hope for Frank and Anne.

The Elaboration, Sheet Music: Poems 1967-1982, Collected Poems

A Scottish Bride

Zoetropes, Zoetropes: Poems 1972-82, Sheet Music: Poems 1967-1982, Collected Poems (attributed to Zoetropes)

A Song about the Moon

Good Looks, Zoetropes: Poems 1972-82, Sheet Music: Poems 1967-1982, Collected Poems

A Winter Christmas........................................ Milky Way Bar, Collected Poems

Adélie.............. What to Call Your Child, Collected Poems

Agitated Nation........................................ Milky Way Bar, Collected Poems

Ain Folks.............................................. My Sunshine, Collected Poems

Allen Curnow Meets Judge Dredd........................... Milky Way Bar, Collected Poems

America................................................. What to Call Your Child, Collected Poems

An Amazing Week in New Zealand.......................... An Amazing Week in New Zealand, My Sunshine, Collected Poems

An American Marriage ................................... My Sunshine, Collected Poems

An Extended Family ....................................... Milky Way Bar, Collected Poems

An Outline .............................................. Good Looks, Zoetropes: Poems 1972-82, Sheet Music: Poems 1967-1982, Collected Poems

Antarctic Stone............................................... Homelight: An Antarctic Miscellany, what to call your child, Collected Poems

Aubade.

What to Call Your Child, Collected Poems

Beach Life.................................................. Milky Way Bar, Collected Poems

Between Drinks. Collected Poems (attributed to What to Call Your Child)

Between the Cough and the Howl............................ My Sunshine, Collected Poems

Blade \& Swing............................................... My Sunshine, Collected Poems

Blood Falls..................................................... What to Call Your Child, Collected Poems

Blue Flower............................................. What to Call Your Child, Collected Poems

Bones ... How to Take Off Your Clothes at the Picnic, Sheet Music: Poems 1967-1982, Collected Poems

Brazil....................................................... Milky Way Bar, Collected Poems

Breakfast (Damp white eggs...)._._. Good Looks, Sheet Music: Poems 1967-1982, Collected Poems

Breakfast (Free headphones all...)....................... Zoetropes: Poems 1972-82, Sheet Music: Poems 1967-1982, Collected Poems

Breaking the Habit.......................................... Milky Way Bar, Collected Poems

Buckets................................................... The Old Man's Example, Sheet Music: Poems 1967-1982, Collected Poems

Cape Royds............................................... What to Call Your Child, Collected Poems

Children _. Good Looks, Zoetropes: Poems 1972-82, Sheet Music: Poems 1967-1982, Collected Poems

City Life............................................. How to Take Off Your Clothes at the Picnic, Zoetropes: Poems 1972-82, Sheet Music: Poems 1967-1982, Collected Poems

Clouds .

Contemplation of the Heavens............................. How to Take Off Your Clothes at the Picnic, Zoetropes: Poems 1972-82, Sheet Music: Poems 1967-1982, Collected Poems 


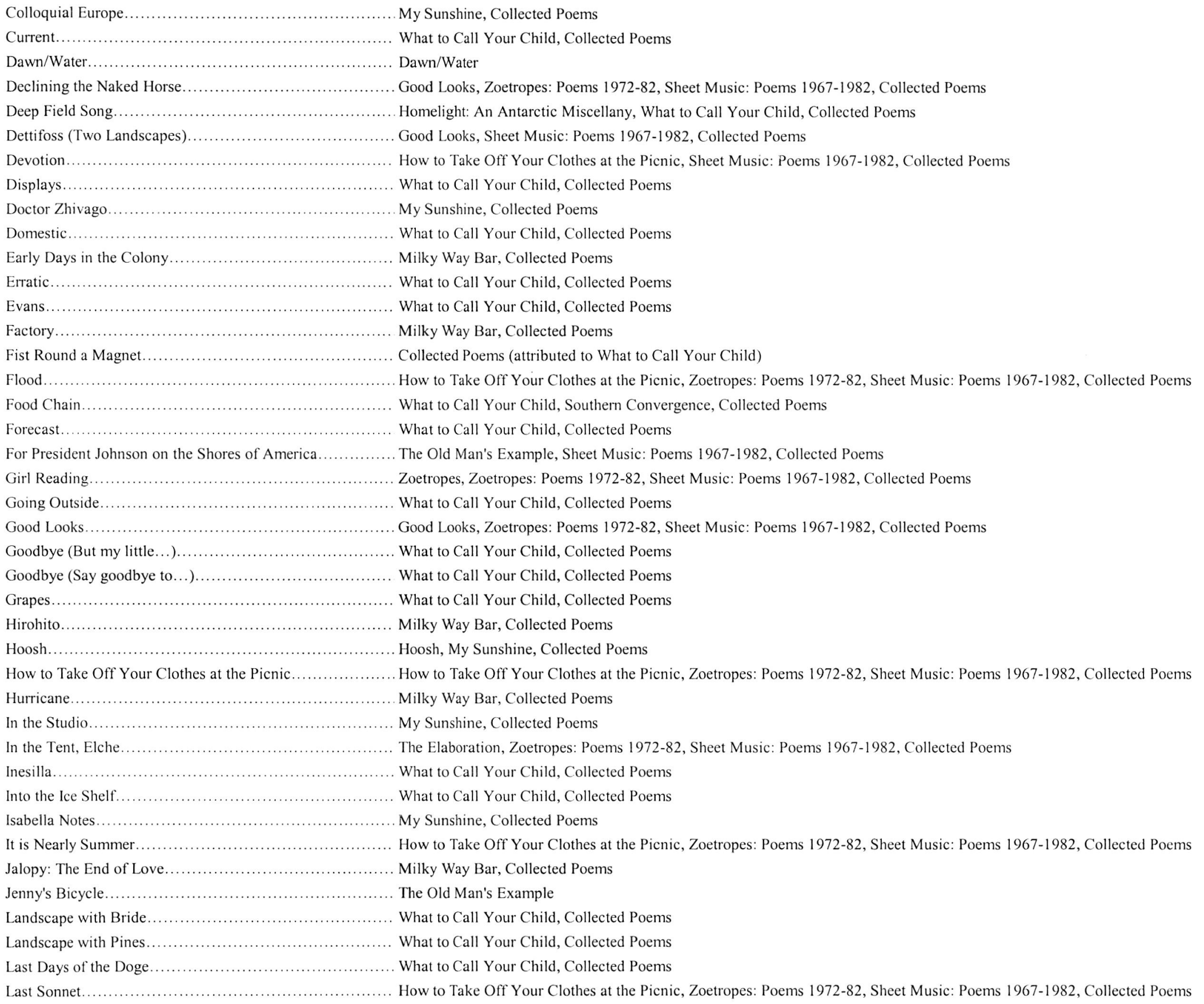




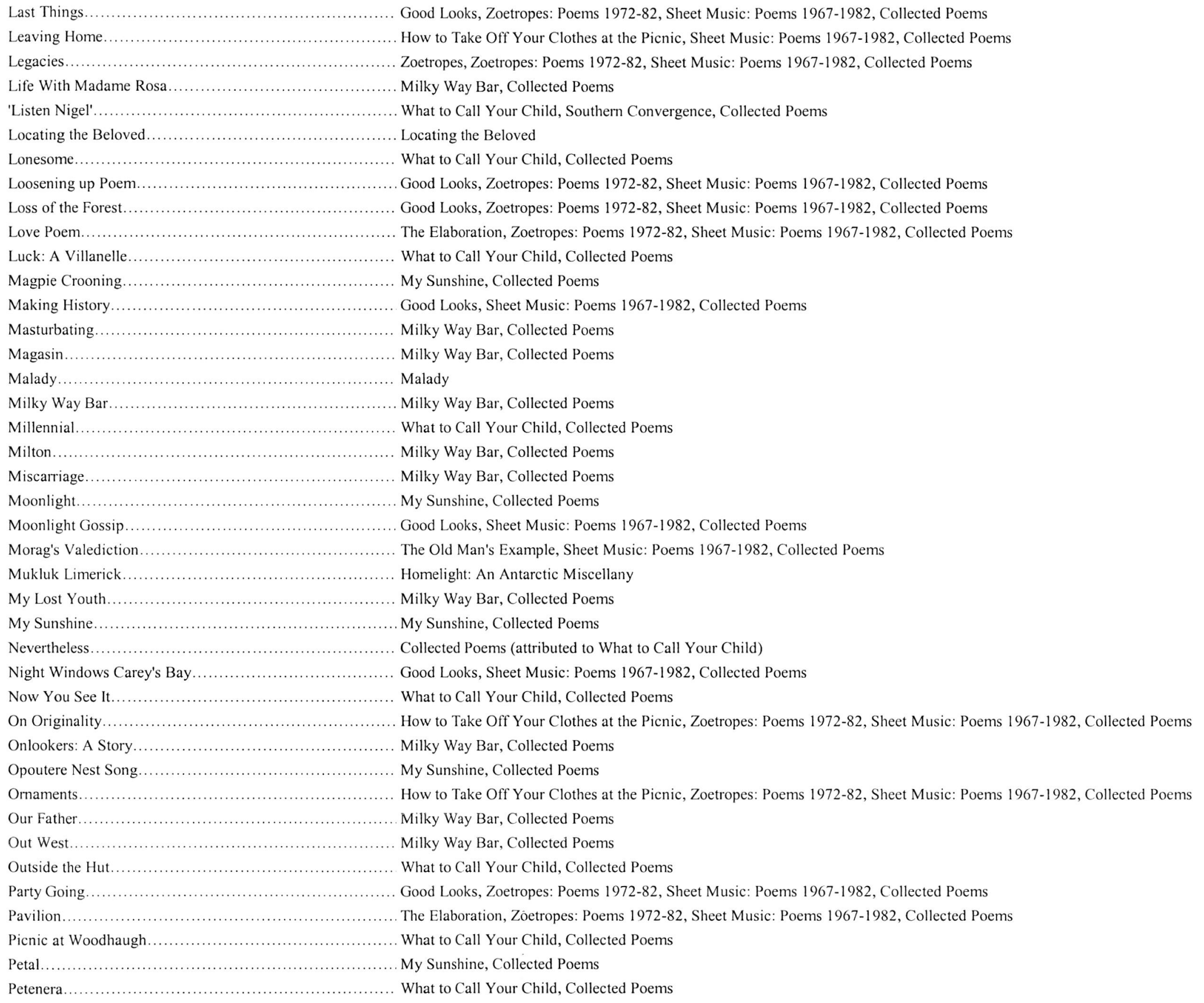


Phar Lap........................................... Milky Way Bar, Collected Poems

Pledge ....................................................... What to Call Your Child, Collected Poems

Poem (In my songs...).................................... The Old Man's Example, Sheet Music: Poems 1967-1982, Collected Poems

Poem (When we touch....................................... The Elaboration, Zoetropes: Poems 1972-82, Sheet Music: Poems 1967-1982, Collected Poems

Poem Against the Natural World............................. Good Looks, Sheet Music: Poems 1967-1982, Collected Poems

Poem for Vanessa .......................................... Good Looks, Zoetropes: Poems 1972-82, Sheet Music: Poems 1967-1982, Collected Poems

Poetics.................................................. The Old Man's Example, Sheet Music: Poems 1967-1982, Collected Poems

Princess: The Treatment...................................... Milky Way Bar, Collected Poems

Recovered Noah ....................................... What to Call Your Child, Collected Poems

Red Dream................................................ My Sunshine, Collected Poems

Red Horse ...................................................... Good Looks, Zoetropes: Poems 1972-82, Sheet Music: Poems 1967-1982, Collected Poems

Remarkables................................................ My Sunshine, Collected Poems

Riddle (Like a dwelling......................................... Good Looks, Zoetropes: Poems 1972-82, Sheet Music: Poems 1967-1982, Collected Poems

Riddle (The breath still...)................................ What to Call Your Child, Collected Poems (attributed to Good Looks)

Scavenger............. What to Call Your Child, Southern Convergence, Collected Poems

She Says................................................. Zoetropes: Poems 1972-82, Sheet Music: Poems 1967-1982, Collected Poems

Some Epithets....................................... to Take Off Your Clothes at the Picnic, Good Looks, Zoetropes: Poems 1972-82, Sheet Music: Poems 1967-1982, Collected Poems

Some Frames................................................... What to Call Your Child, Collected Poems

Some Screens ........................................... My Sunshine, Collected Poems

Song......................................................... What to Call Your Child, Collected Poems

Sounding the Dark........................................... Collected Poems (Attributed to The Old Man's Example)

South Island Companion...................................... Milky Way Bar, Collected Poems

Summer.................................................. How to Take Off Your Clothes at

Synopsis (Handel's Imeneo )................................. Milky Way Bar, Collected Poems

The Adventures of Hillary..................................... My Sunshine, Collected Poems

The Afterlife........................................... Good Looks, Zoetropes: Poems 1972-82, Sheet Music: Poems 1967-1982, Collected Poems

The Album..................................................... What to Call Your Child, Collected Poems

The Anglo-Saxon Onion .................................... Good Looks, Zoetropes: Poems 1972-82, Sheet Music: Poems 1967-1982, Collected Poems

The Breakfast Session................... Good Looks, Zoetropes: Poems 1972-82, Sheet Music: Poems 1967-1982, Collected Poems

The Buried Soap .......................................... Good Looks, Zoetropes: Poems 1972-82, Sheet Music: Poems 1967-1982, Collected Poems

The Calendar........................................ How to Take Off Your Clothes at the Picnic, Sheet Music: Poems 1967-1982, Collected Poems

The Caravan.................................................. Good Looks, Zoetropes: Poems 1972-82, Sheet Music: Poems 1967-1982, Collected Poems

The Cinema ............................................ How to Take Off Your Clothes at the Picnic, Zoetropes: Poems 1972-82, Sheet Music: Poems 1967-1982, Collected Poems

The Clown at the Death of His Wife....................... The Old Man's Example, Sheet Music: Poems 1967-1982, Collected Poems

The Coast............................................ How to Take Off Your Clothes at the Picnic, Zoetropes: Poems 1972-82, Sheet Music: Poems 1967-1982, Collected Poems

The Collaboration....................................... How to Take Off Your Clothes at the Picnic, Sheet Music: Poems 1967-1982, Collected Poems

The Collection.............................................. How to Take Off Your Clothes at the Picnic, Sheet Music: Poems 1967-1982, Collected Poems

The Contract............................................... How to Take Off Your Clothes at the Picnic, Sheet Music: Poems 1967-1982, Collected Poems

The Directory ........................................ How to Take Off Your Clothes at the Picnic, Sheet Music: Poems 1967-1982, Collected Poems

The Distance Between Bodies.............................. Zoetropes, Zoetropes: Poems 1972-82, Sheet Music: Poems 1967-1982, Collected Poems

The Dream 
The Elaboration

The English Teacher..

The Elaboration, Zoetropes: Poems 1972-82, Sheet Music: Poems 1967-1982, Collected Poems

The Friends.

The God Who Watches over All Perhaps. My Sunshine, Collected Poems

The Gong...........

The Great Fire of Toronto.................................. My Sunshine, Collected Poems

How to Take Off Your Clothes at the Picnic, Sheet Music: Poems 1967-1982, Collected Poems

The Old Man's Example, Sheet Music: Poems 1967-1982, Collected Poems

The Hut .................................................... What to Call Your Child, Collected Poems

The Idiot: A Pastoral.................................... Good Looks, Zoetropes: Poems 1972-82, Sheet Music: Poems 1967-1982, Collected Poems

The Importance of Personal Relationships.................. How to Take Off Your Clothes at the Picnic, Zoetropes: Poems 1972-82, Sheet Music: Poems 1967-1982, Collected Poems

The Incision_- How to Take Off Your Clothes at the Picnic, Zoetropes: Poems 1972-82, Sheet Music: Poems 1967-1982, Collected Poems

The Kiss.............................................. How to Take Off Your Clothes at the Picnic, Zoetropes: Poems 1972-82, Sheet Music: Poems 1967-1982, Collected Poems

The L \& R Song ........................................... How to Take Off Your Clothes at the Picnic, Sheet Music: Poems 1967-1982, Collected Poems

The Late Victorian Girl..................................... Good Looks, Zoetropes: Poems 1972-82, Sheet Music: Poems 1967-1982, Collected Poems

The Missing Children........................................ My Sunshine, Collected Poems

The Mutability Cantos..................................... How to Take Off Your Clothes at the Picnic, Zoetropes: Poems 1972-82, Sheet Music: Poems 1967-1982, Collected Poems

The Next Thousand .................................... Collected Poems

The Occupation, Against Time .......................... The Elaboration, Sheet Music: Poems 1967-1982, Collected Poems

The Old Man's Example.................................. The Old Man's Example, Sheet Music: Poems 1967-1982, Collected Poems

The Oreti River............................................. The Old Man's Example, Sheet Music: Poems 1967-1982, Collected Poems

The Paperweight.......................................... How to Take Off Your Clothes at the Picnic, Zoetropes: Poems 1972-82, Sheet Music: Poems 1967-1982, Collected Poems

The Pickpocket.......................................... How to Take Off Your Clothes at the Picnic, Zoetropes: Poems 1972-82, Sheet Music: Poems 1967-1982, Collected Poems

The Poetry Reading...................................... How to Take Off Your Clothes at the Picnic, Zoetropes: Poems 1972-82, Sheet Music: Poems 1967-1982, Collected Poems

The Polar Explorer's Love Song ............................. Homelight: An Antarctic Miscellany, what to call your child, Collected Poems

The Prairie Poet...................................... My Sunshine, Collected Poems

The Prayer............................................. The Elaboration, Zoetropes: Poems 1972-82, Sheet Music: Poems 1967-1982, Collected Poems

The Procedure ............................................ How to Take Off Your Clothes at the Picnic, Sheet Music: Poems 1967-1982, Collected Poems

The Proof .................................................. The Elaboration, Sheet Music: Poems 1967-1982, Collected Poems

The Proposition ...................................... How to Take Off Your Clothes at the Picnic, Zoetropes: Poems 1972-82, Sheet Music: Poems 1967-1982, Collected Poems

The River.............................................. The Elaboration, Sheet Music: Poems 1967-1982, Collected Poems

The Seasons / If I Will Sing There ........................... The Elaboration, Sheet Music: Poems 1967-1982, Collected Poems

The Selenologist.......................................... Good Looks, Zoetropes: Poems 1972-82, Sheet Music: Poems 1967-1982, Collected Poems

The Snow............................................. to Take Off Your Clothes at the Picnic, Sheet Music: Poems 1967-1982, Collected Poems

The Song ............................................... How to Take Off Your Clothes at the Picnic, Zoetropes: Poems 1972-82, Sheet Music: Poems 1967-1982, Collected Poems

The Spell .............................................. The Elaboration, Zoetropes: Poems 1972-82, Sheet Music: Poems 1967-1982, Collected Poems

The Swallow................................................... Good Looks, Zoetropes: Poems 1972-82, Sheet Music: Poems 1967-1982, Collected Poems

The Trees.................................................. How to Take Off Your Clothes at the Pienic, Zoetropes: Poems 1972-82, Sheet Music: Poems 1967-1982, Collected Poems

The Visitor................................................. The Old Man's Example, Sheet Music: Poems 1967-1982, Collected Poems

The Voyage ........................................... The Elaboration, Zoetropes: Poems 1972-82, Sheet Music: Poems 1967-1982, Collected Poems

The Voyeur: An Imitation.................................... Good Looks, Zoetropes: Poems 1972-82, Sheet Music: Poems 1967-1982, Collected Poems

The White Pebble .................................. The Elaboration, Zoetropes: Poems 1972-82, Sheet Music: Poems 1967-1982, Collected Poems

Time Lapse .................................................. What to Call Your Child, Collected Poems 
Turtle.......

How to Take Off Your Clothes at the Picnic, Sheet Music: Poems 1967-1982, Collected Poems

Two Landscapes (Wingatui and Dettifoss) Good Looks

The Elaboration, Sheet Music: Poems 1967-1982, Collected Poems

Valedictory.......

What to Call Your Child, Collected Poems

Vanessa's Song......................... Good Looks, Zoetropes: Poems 1972-82, Sheet Music: Poems 1967-1982, Collected Poems

Vidyapati's Song

Good Looks, Sheet Music: Poems 1967-1982, Collected Poems

Visiting Mr Shackleton.......

Homelight: An Antarctic Miscellany, what to call your child, Collected Poems

Watching Alison in Winter.

The Elaboration, Sheet Music: Poems 1967-1982, Collected Poem

Water, A Stopping Place

Zoetropes, Zoetropes: Poems 1972-82, Sheet Music: Poems 1967-1982, Collected Poems

Wellington...

(1967-1982, Collected Poems

Wen

Good Looks, Sheet Music: Poems 1967-1982, Collected Poems

What it Means to be Naked

Good Looks, Zoetropes: Poems 1972-82, Sheet Music: Poems 1967-1982, Collected Poems

What to Call Your Child

What to Call Your Child, Collected Poems

When You're Dead You Go on Television....

Good Looks, Zoetropes: Poems 1972-82, Sheet Music: Poems 1967-1982, Collected Poems

Wingatui (Two Landscapes)

Wings

The Old Man's Example, Sheet Music: Poems 1967-1982, Collected Poems

Wintrous

How to Take Off Your Clothes at the Picnic, Sheet Music: Poems 1967-1982, Collected Poems

Wulf

Good Looks, Zoetropes: Poems 1972-82, Sheet Music: Poems 1967-1982, Collected Poems

You: A Fragment

Good Looks, Zoetropes: Poems 1972-82, Sheet Music: Poems 1967-1982, Collected Poems

Your Absence.

The Elaboration, Sheet Music: Poems 1967-1982, Collected Poem

Your Room

The Old Man's Example, Sheet Music: Poems 1967-1982, Collected Poems

Zoetropes....

Zoetropes, Zoetropes: Poems 1972-82, Sheet Music: Poems 1967-1982, Collected Poems 


\section{First Sentence Index}

\section{First Sentence}

Aarey Milk Colony, .

Clinton threw his schoolbag through the door and raced in after it.

It was just after the assassination of Indira Gandhi that I came into the

employ of Jason Michael Stretch.

e says: 'Give me something significant.'

High above the Australian interior I sit in a Malaysian Airlines DC10 -

knees under my chin, Wings of Gold on my knees.

Q. Through here?

She had what people are given to describe as heavy, sensuous lips:

a kind of fracture that opened across her face. .......................

That's good then, says Emily to Mr Bliss who shuffles between his two

blue suitcases.

There is a photograph of early Dunedin, taken from the top of the Town

Hall in 1883 .

The bishops come ashore.

The poet looks at the poet's wife and says: You are my best poem.

The woman from the Historic Places Trust is nervous. ....

They are in Rotorua, but the Bellevue no longer has a view and is

$$
\text { also double-booked. }
$$

They were travelling in a part of the country famous for its waterfalls.

Two days before he left New Zealand Allen received a phone call.

We were sailing in the Pacific.

You are just an ordinary New Zealander.

\section{Story Title}

Index.

Flights of Angels

Ponies

Songs of My Life....

Wings of Gold: A Week Among Poets

Some Questions I Am Frequently Asked.

Jenny's Bicycle

The Moon at the End of the Century ....

The Days of Sail

Highlights

Siena.

South Pacific.

Cannibals

The Brain of Katherine Mansfield..
Book

The New Land: A Picture Book

South Pacific, Songs of My Life

The New Land: A Picture Book, South Pacific, Songs of My Life

South Pacific, Songs of My Life

South Pacific, Songs of My Life

The New Land: A Picture Book, South Pacific, Songs of My Life

South Pacific, Songs of My Life

South Pacific, Songs of My Life

The New Land: A Picture Book, South Pacific, Songs of My Life The New Land: A Picture Book, South Pacific, Songs of My Life South Pacific, Songs of My Life

The New Land: A Picture Book, South Pacific, Songs of My Life

The New Land: A Picture Book, South Pacific, Songs of My Life The New Land: A Picture Book, South Pacific, Songs of My Life The New Land: A Picture Book, South Pacific, Songs of My Life The New Land: A Picture Book, South Pacific, Songs of My Life . The Brain of Katherine Mansfield, South Pacific, Songs of My Life 


\section{Story Title Index}

Story Title

Book

Cannibals.

Flights of Angels

The New Land: A Picture Book, South Pacific, Songs of My Life South Pacific, Songs of My Life

Highlights

The New Land: A Picture Book, South Pacific, Songs of My Life

Index

The New Land: A Picture Book

Jenny's Bicycle

South Pacific, Songs of My Life

Nonchalance, or The New Land: A Picture Book

The New Land: A Picture Book, South Pacific, Songs of My Life

Ponies

The New Land: A Picture Book, South Pacific, Songs of My Life

Siena....

The New Land: A Picture Book, South Pacific, Songs of My Life

Some Questions I Am Frequently Asked.

The New Land: A Picture Book, South Pacific, Songs of My Life

Songs of My Life.

South Pacific, Songs of My Life

South Pacific........................................ The New Land: A Picture Book, South Pacific, Songs of My Life

The Brain of Katherine Mansfield..

The Brain of Katherine Mansfield, South Pacific, Songs of My Life

The Days of Sail

The New Land: A Picture Book, South Pacific, Songs of My Life

The Moon at the End of the Century....

South Pacific, Songs of My Life

The Poet's Wife..

South Pacific, Songs of My Life

Ventriloquial..............................

The New Land: A Picture Book, South Pacific, Songs of My Life South Pacific, Songs of My Life 


\section{Author Index}

$A$

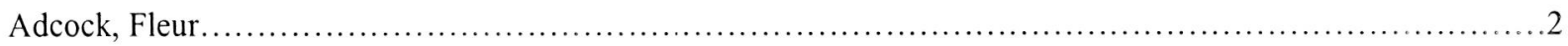

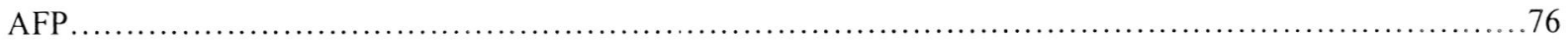

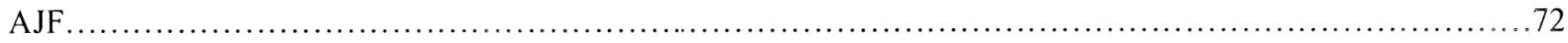

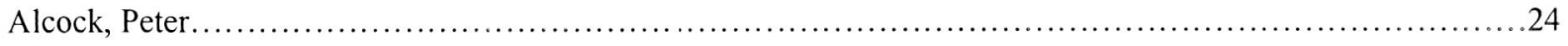

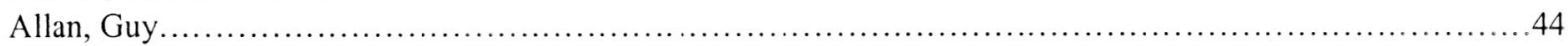

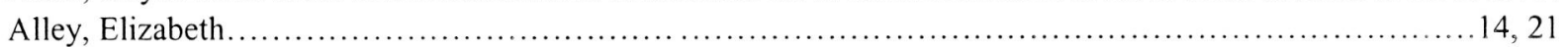

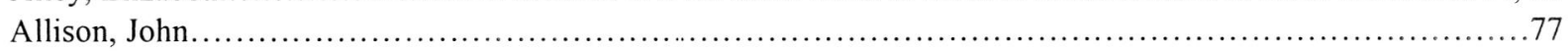

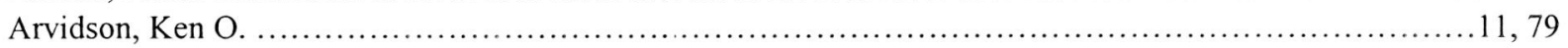

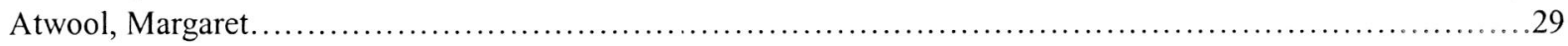

$B$

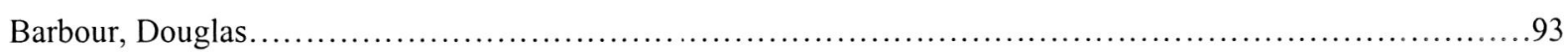

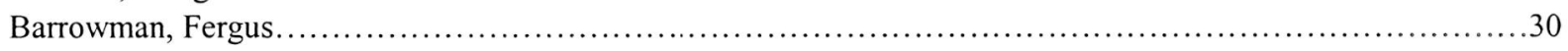

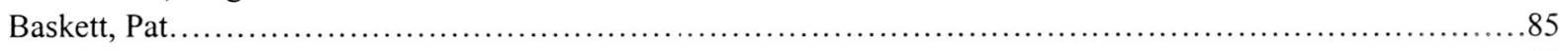

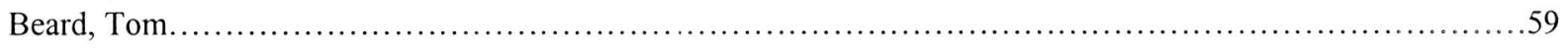

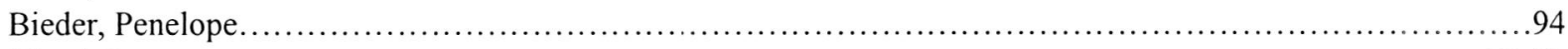

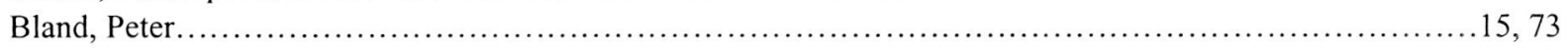

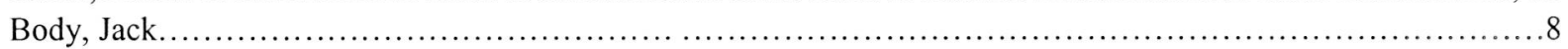

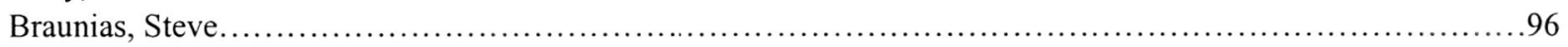

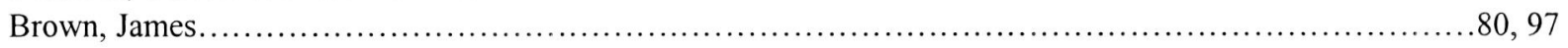

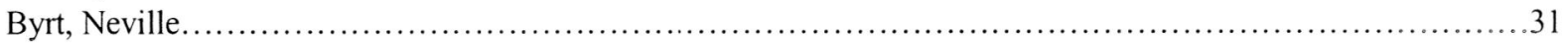

$C$

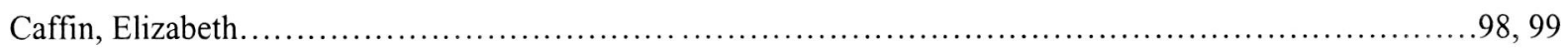

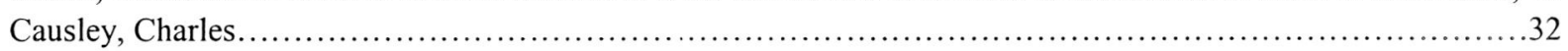

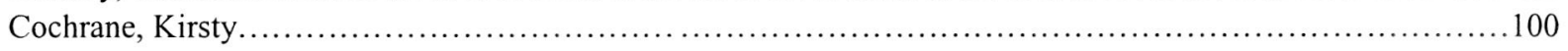

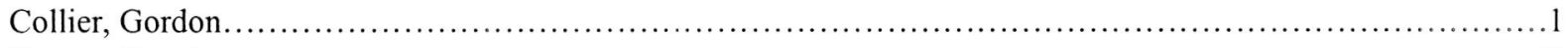

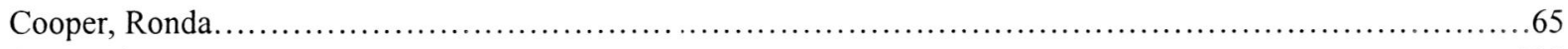

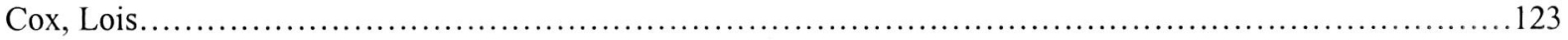

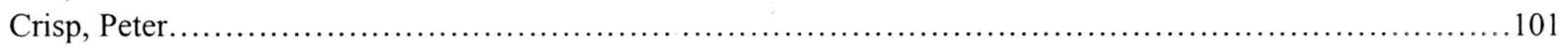

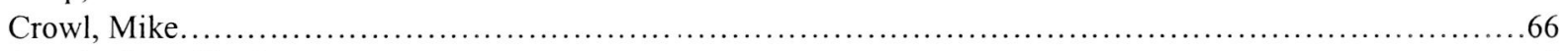

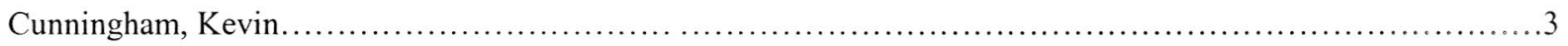

\section{$D$}

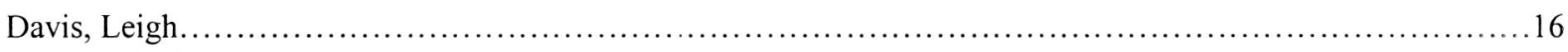

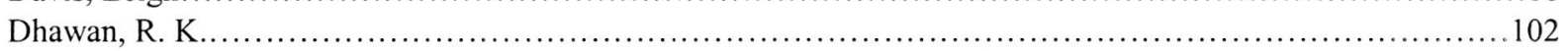

$E$

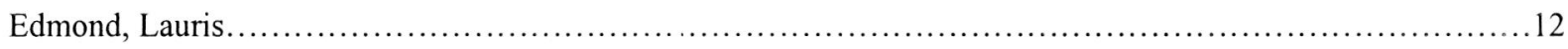

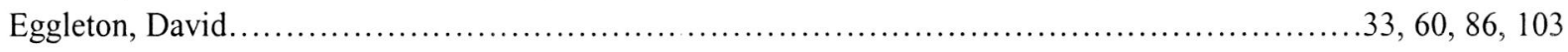

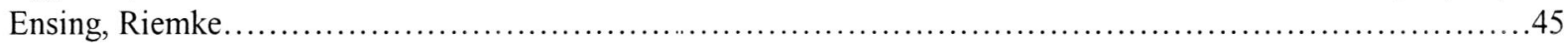

$F$

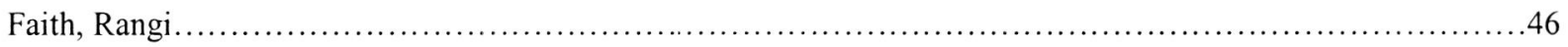

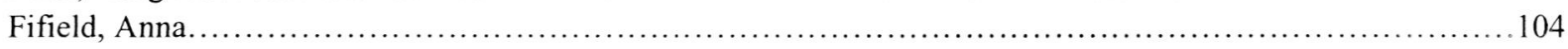

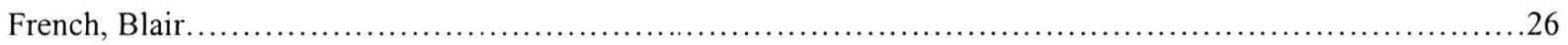




\section{$\boldsymbol{G}$}

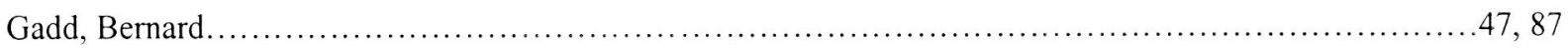

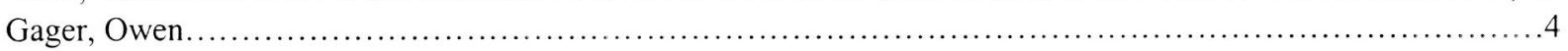

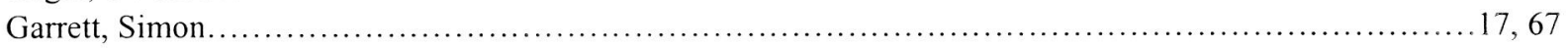

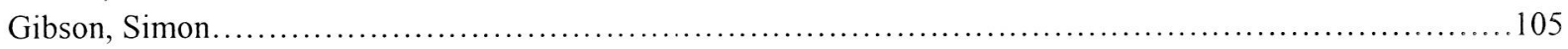

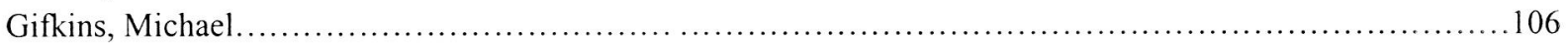

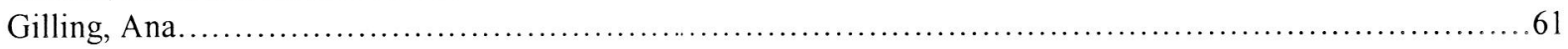

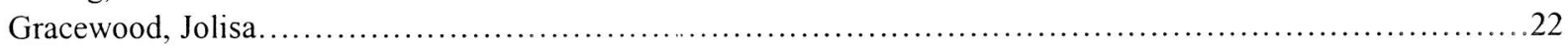

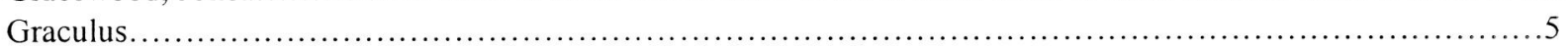

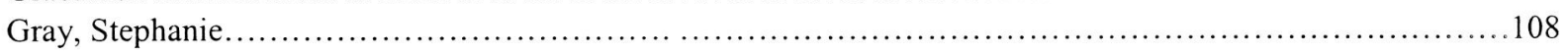

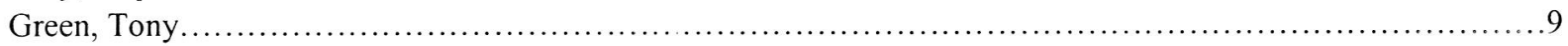

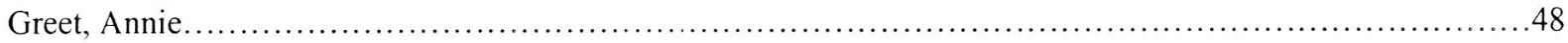

\section{$H$}

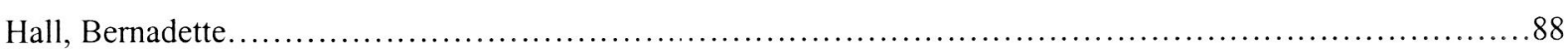

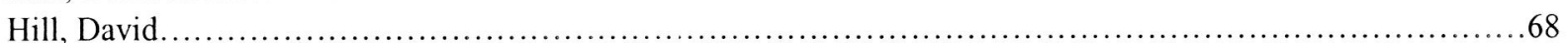

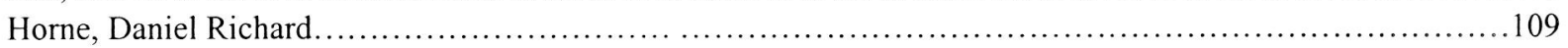

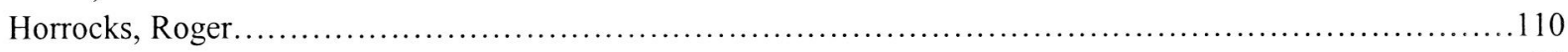

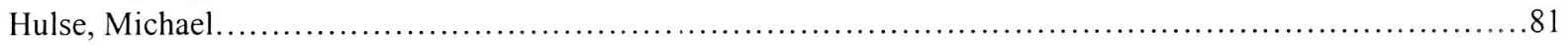

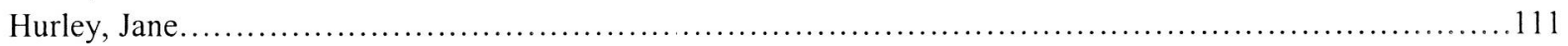

$I$

Isaacs, Clarke.

\section{$J$}

Johnson, Louis.

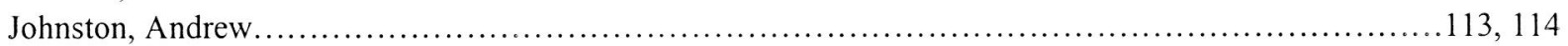

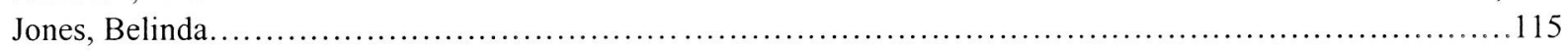

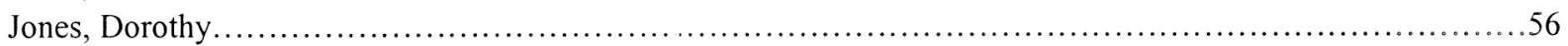

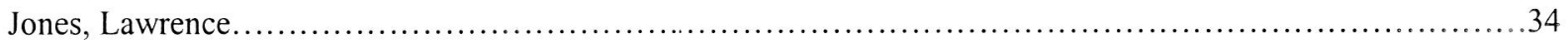

K

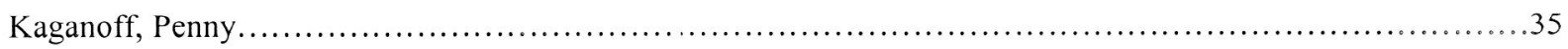

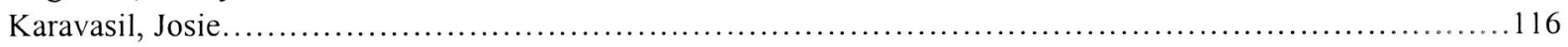

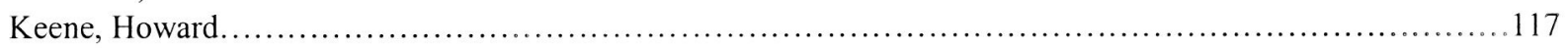

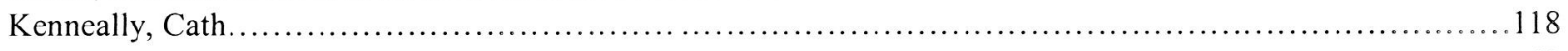

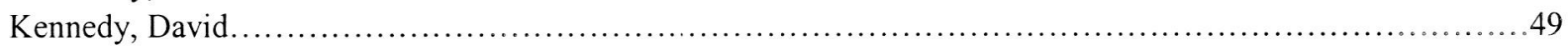

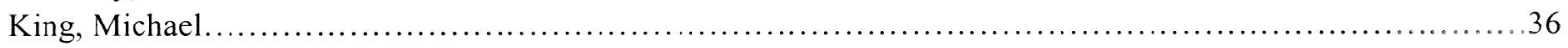

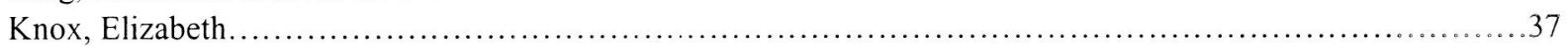

$L$

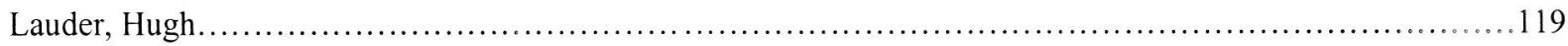

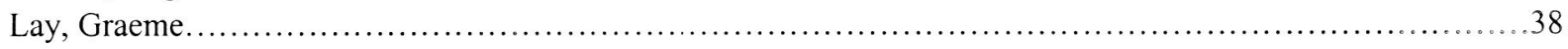

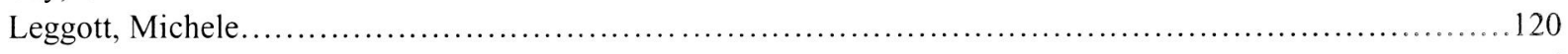

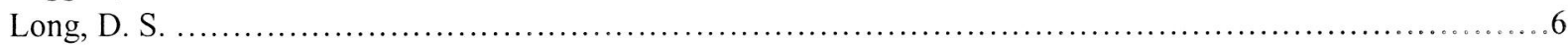


$M$

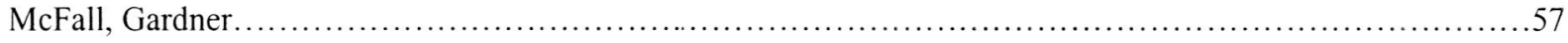

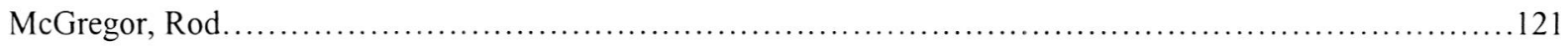

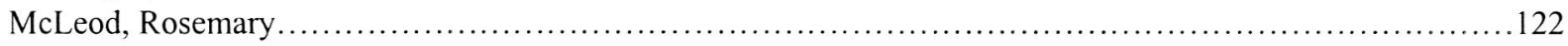

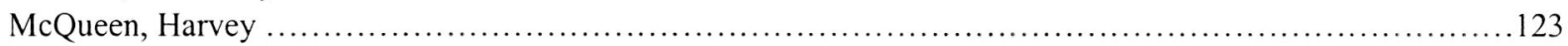

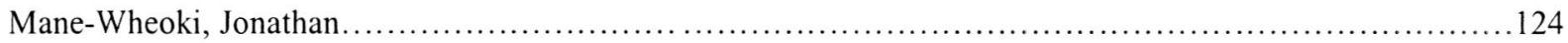

Manhire, Bill............................................................................... 168-180

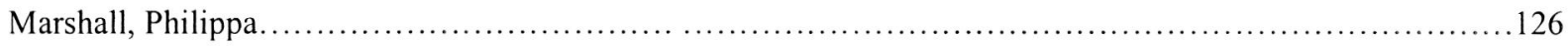

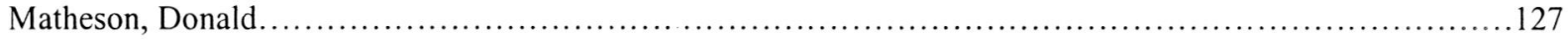

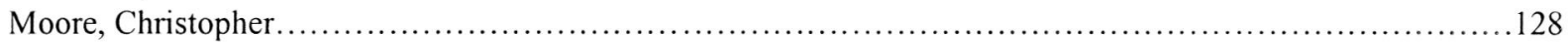

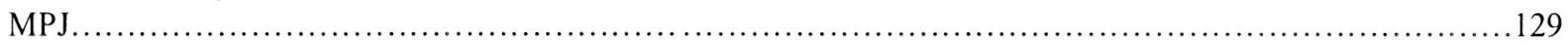

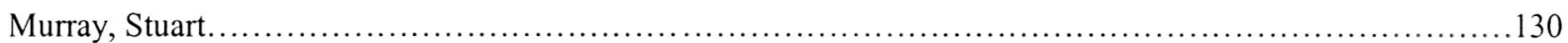

$N$

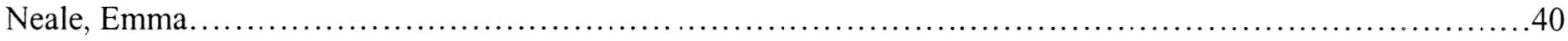

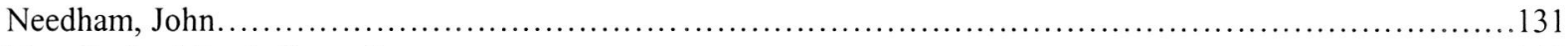

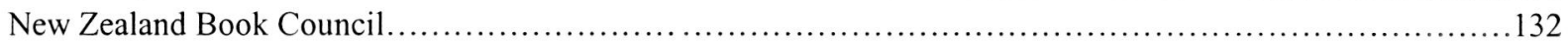

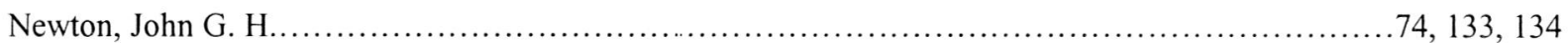

$O$

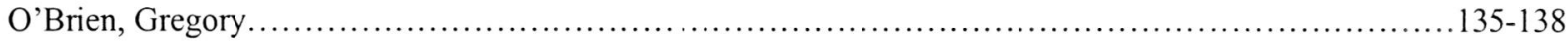

$P$

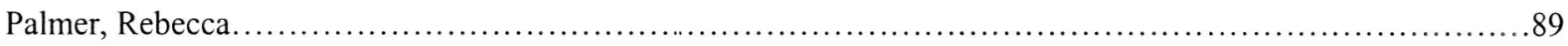

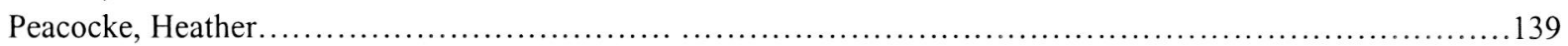

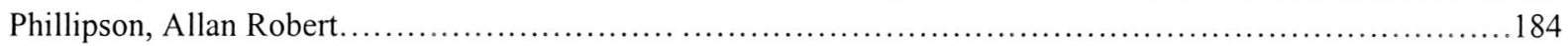

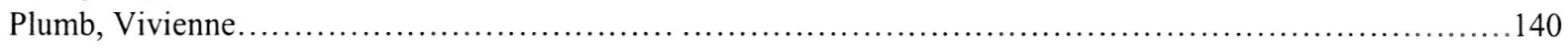

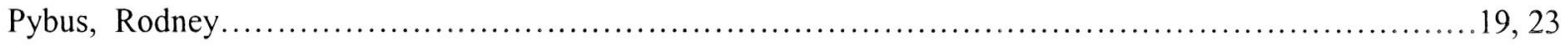

\section{$\boldsymbol{R}$}

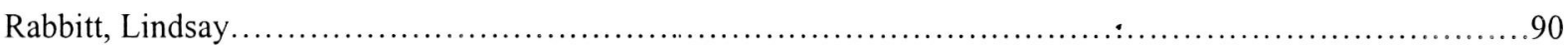

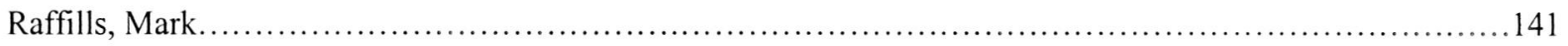

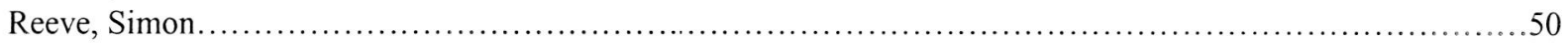

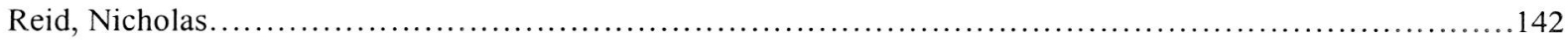

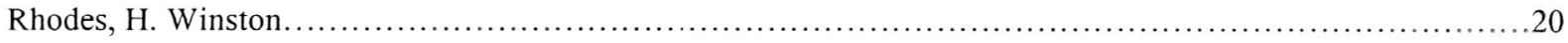

Riach, Alan....................................................................... 51, 62, 82, 144-146

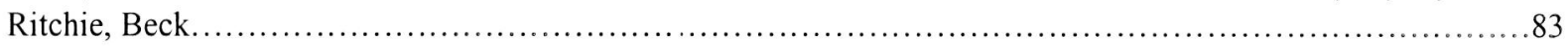

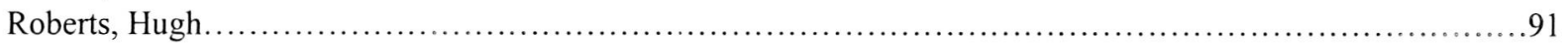

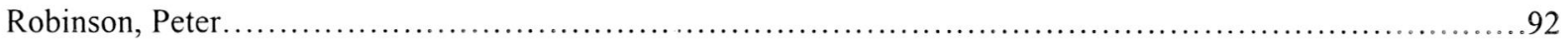

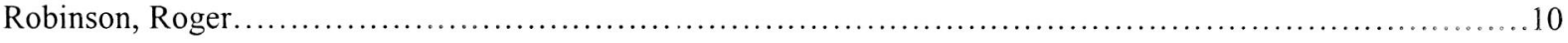

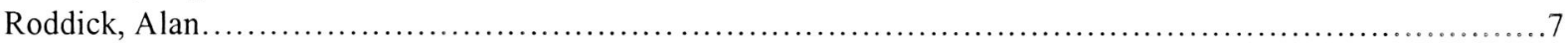




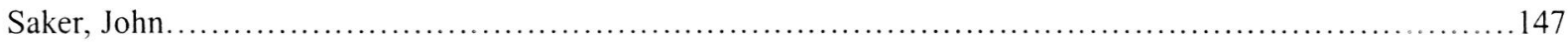

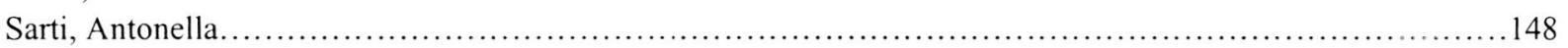

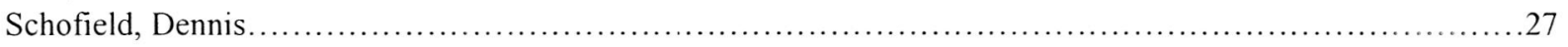

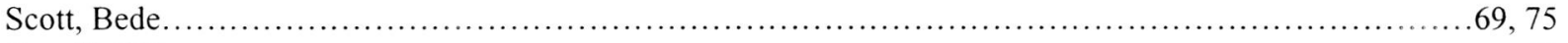

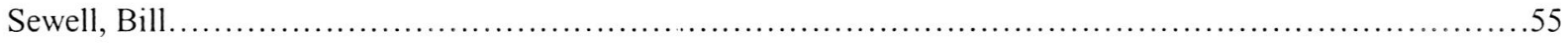

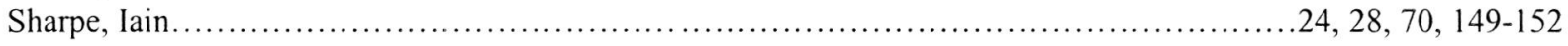

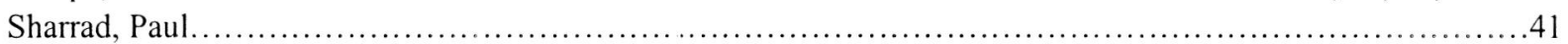

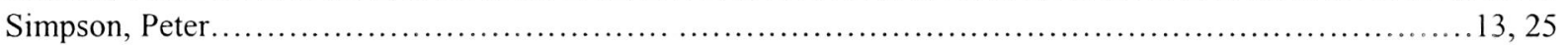

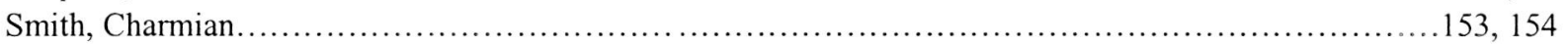

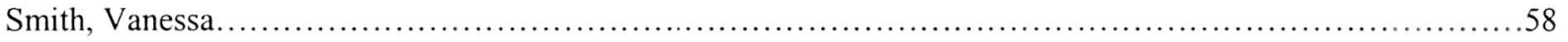

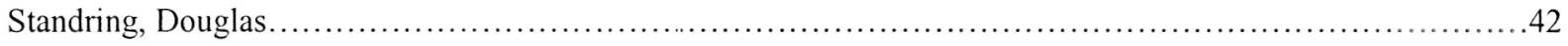

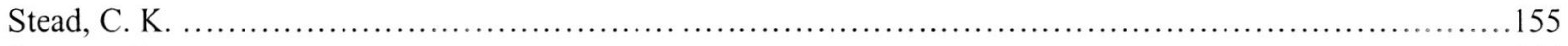

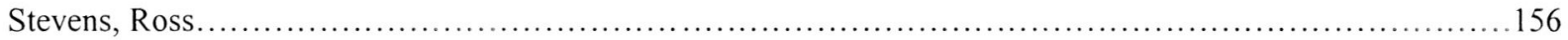

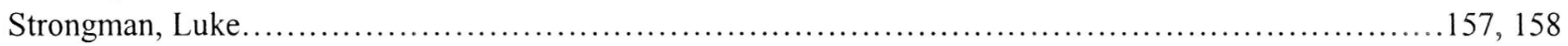

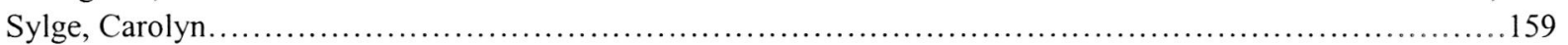

\section{$T$}

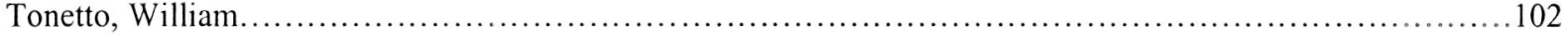

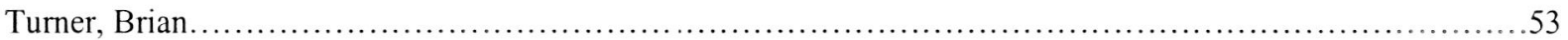

$\boldsymbol{W}$

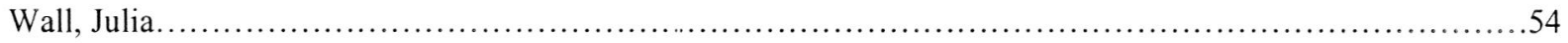

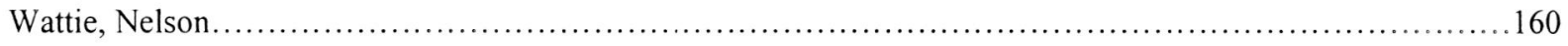

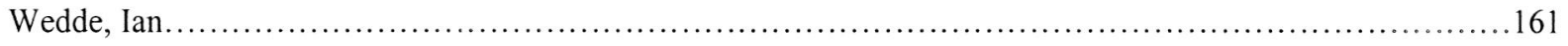

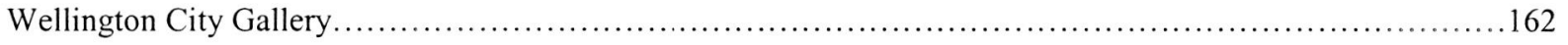

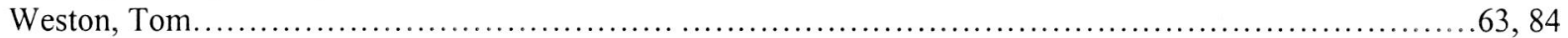

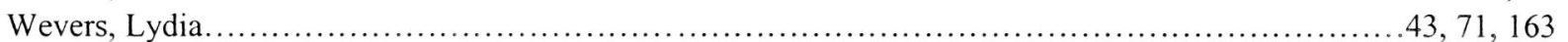

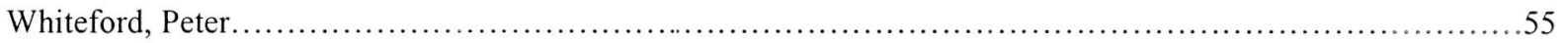

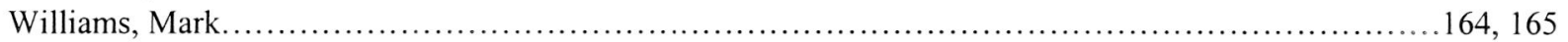

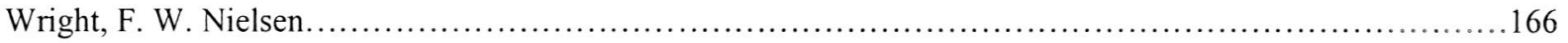

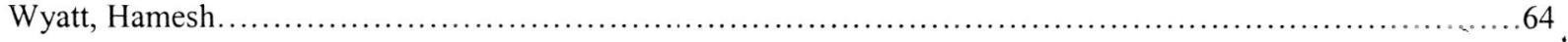




\section{Subject Index}

"A Death in the Family".

$3,5,129,132,133,134,168$

"A Final Secret"

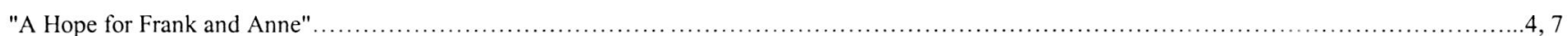

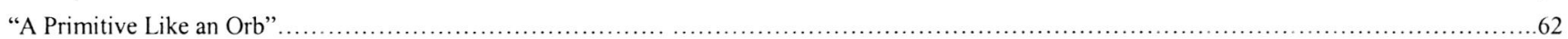

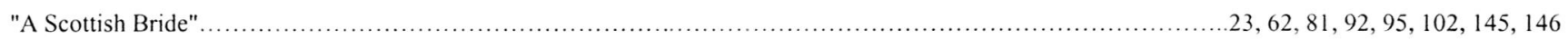

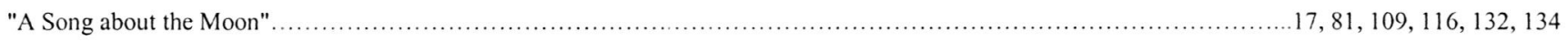

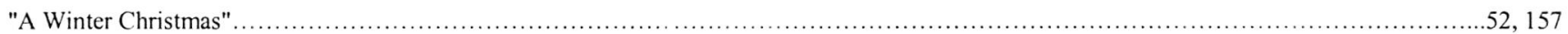

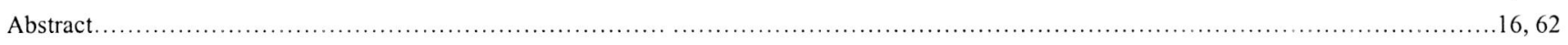

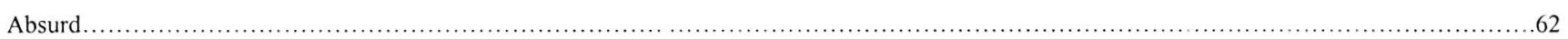

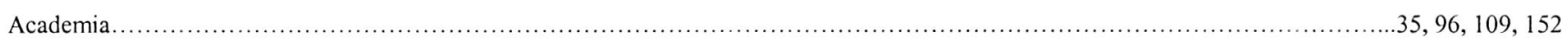

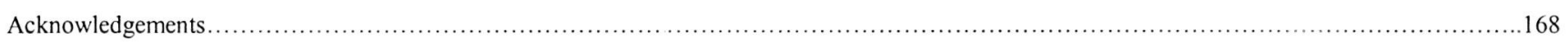

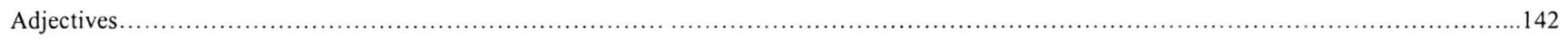

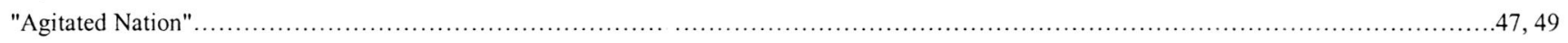

"Ain Folks" ...

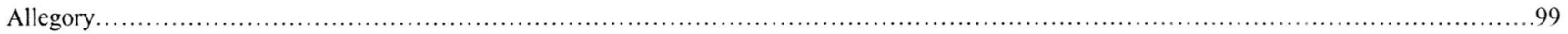

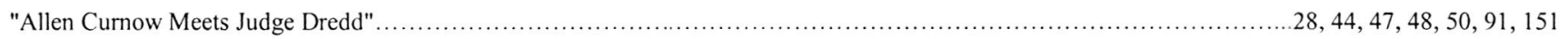

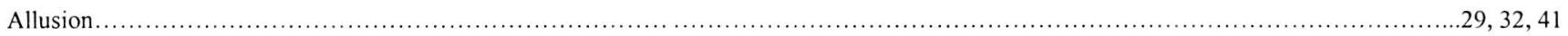

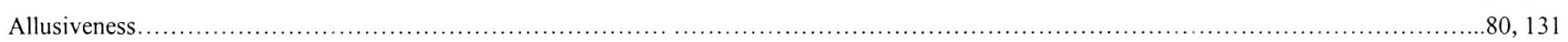

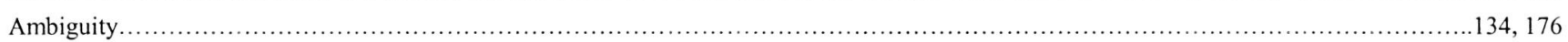

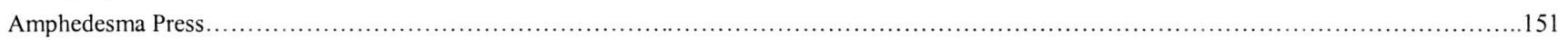

"An Amazing Week in New Zealand".................................................................59, 61, 63, 64, 74, 75, 92, 95, 129, 132, 148, 166

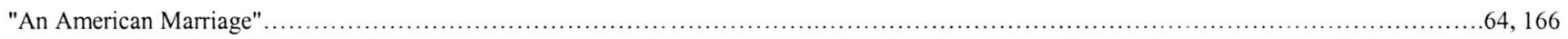

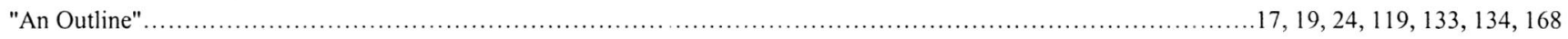

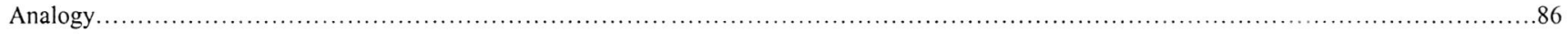

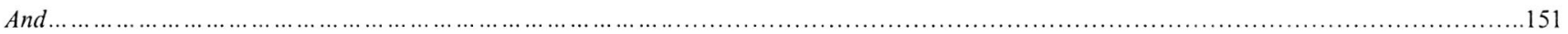

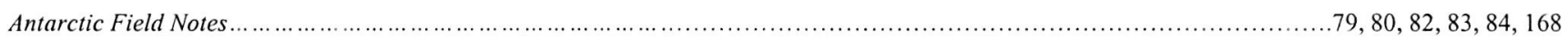

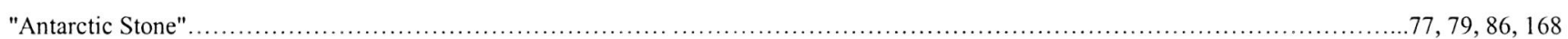

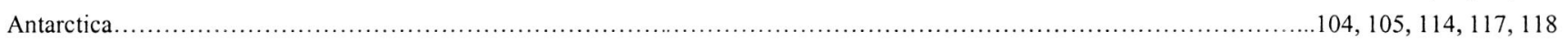

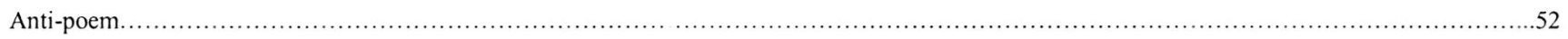

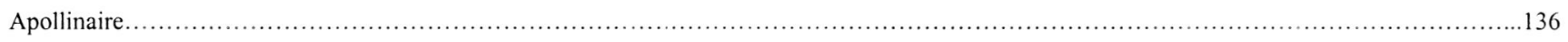

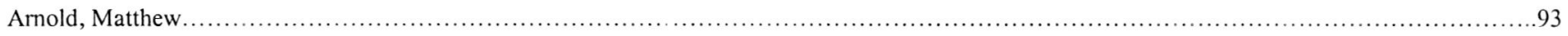

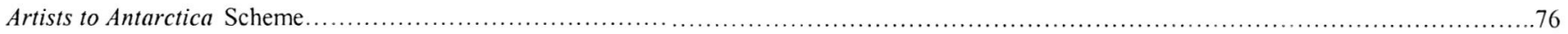

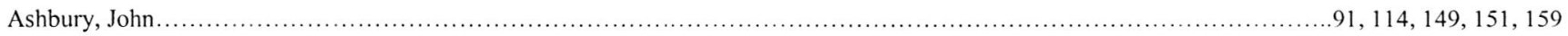

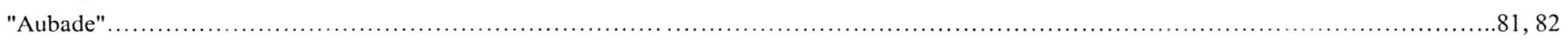

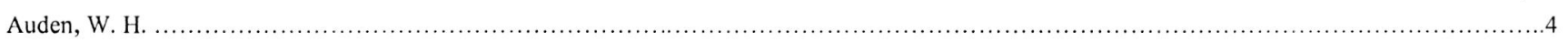

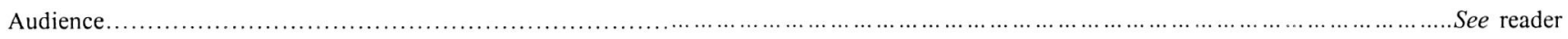

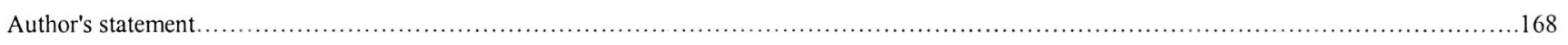

$\boldsymbol{B}$

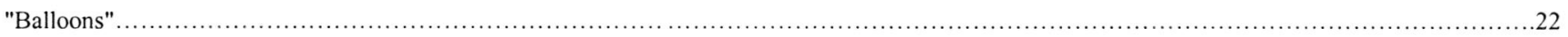

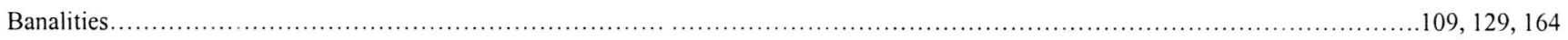

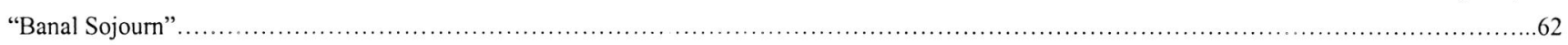

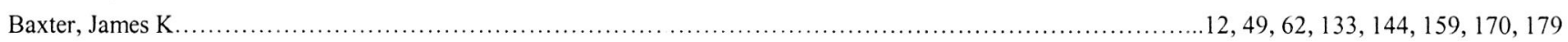

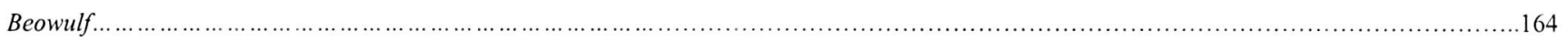

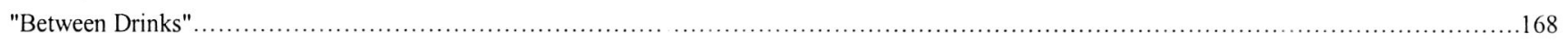

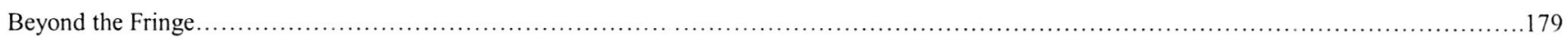

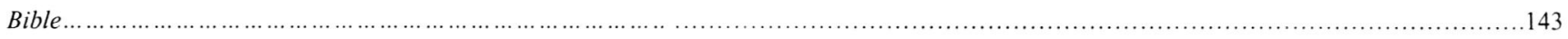

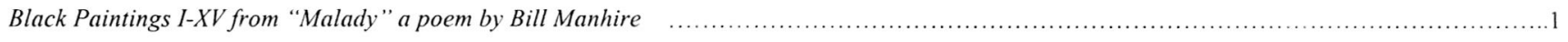

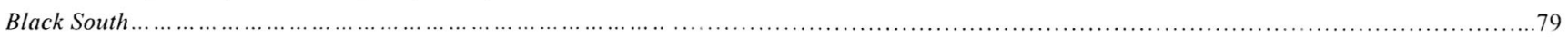


Black Window

"Blade \& Swing"

"Blood Falls"

Bly, Robert.

$24,73,136,151$

Blyton, Enid

"Bones"......

Book of Twentieth-Century Poetry in English (Harvill)..

Bornholdt, Jenny

Bruno S......

Brunton, Alan

"Buckets".

Butor, Michel......

\section{C}

"Cannibals"

$33,34,38,39,41,42,43,56,57,58,62,69,71,94,129,132,163$

"Cape Royds"...

Carcanet....

Characters

$7,27,40,48,58,59,60,71,101,163$

Charms......

Childishness

"Children"

$20,92,98,99,100,119,133,135$

Cliché ....

$23,24,33,41,55,65,68,93,95,98,99,100,110,123,125,129,132$

$152,163,164$

Closed rhyme

Closure..

"Clouds"

Code-switching

$109,144,171$

"Colin".

Collected Poems.

$85-92,132,168$

"Colloquial Europe"

Concert FM... 
$D$

Darkness........

"Declining the Naked Horse".

$24,61,93,95,99,123,132,135,152,177$

"Deep Field Song".

$78,85,128,168,174$

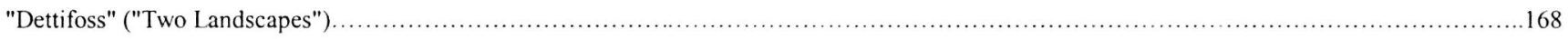

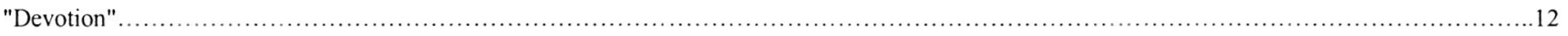

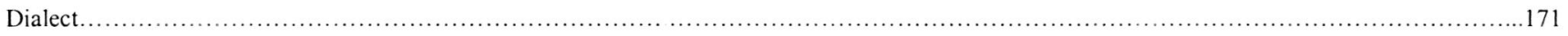

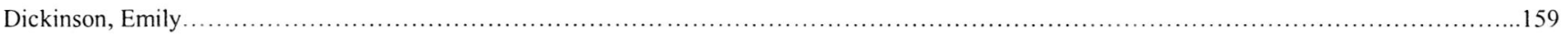

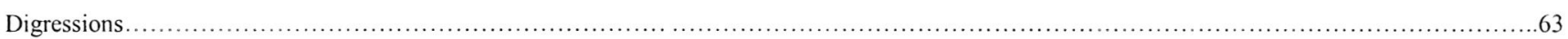

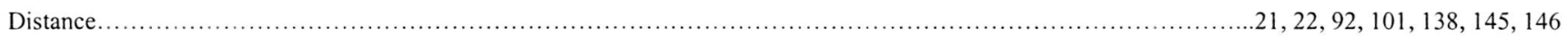

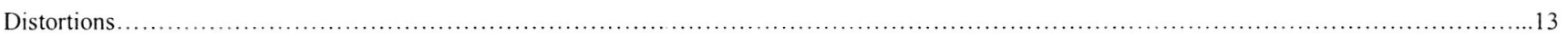

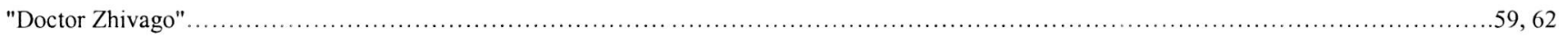

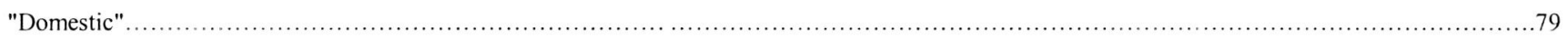

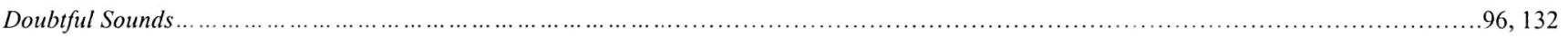

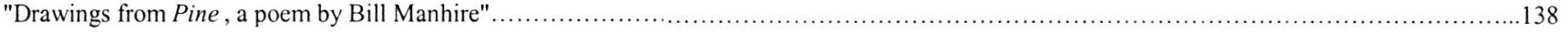

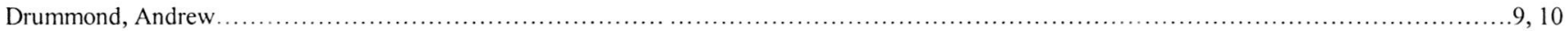

$E$

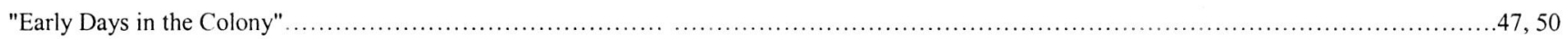

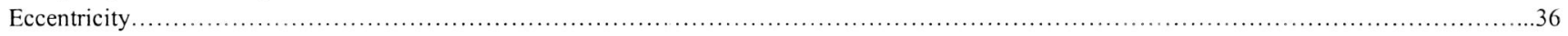

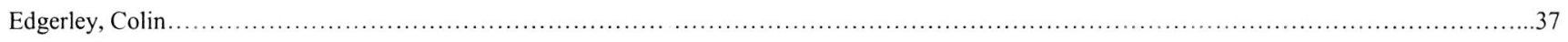

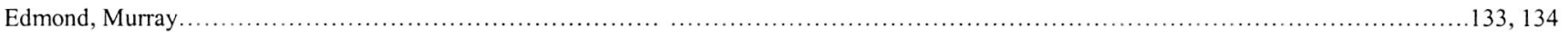

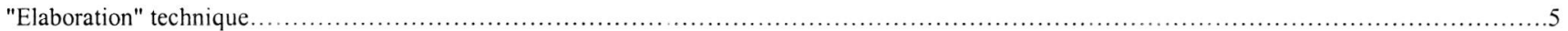

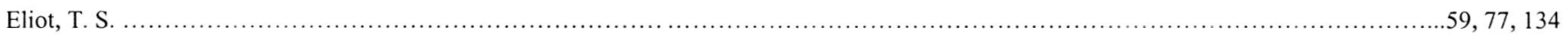

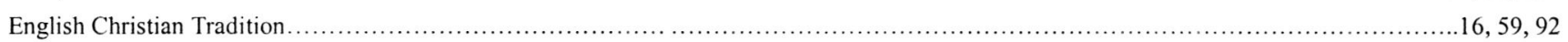

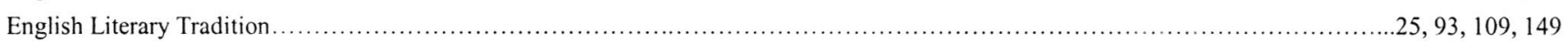

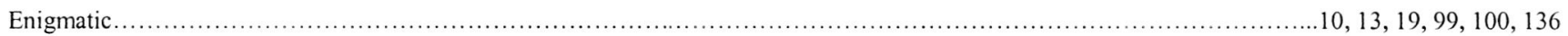

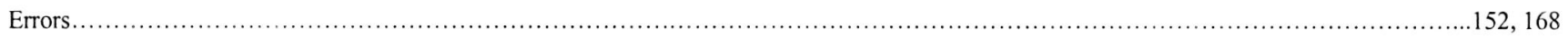

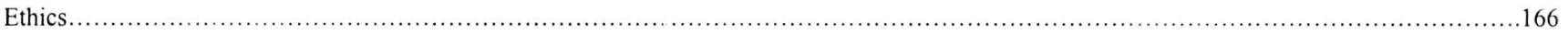

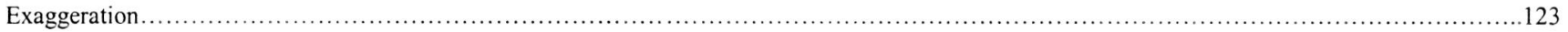

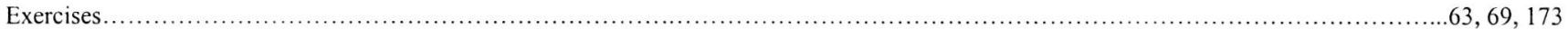

F

"Factory"

.46

Fantasy

$13,34,101,119$

Farce

62

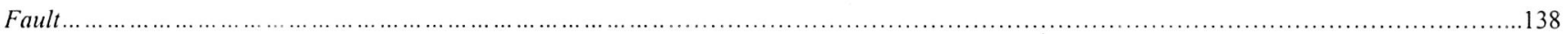

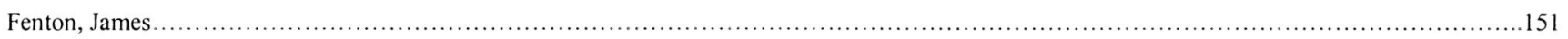

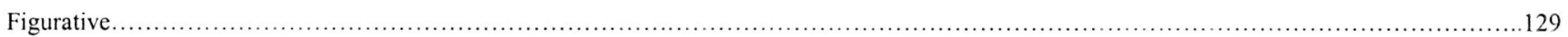

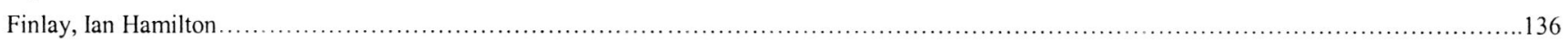

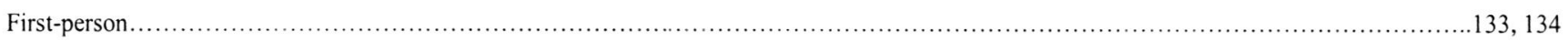

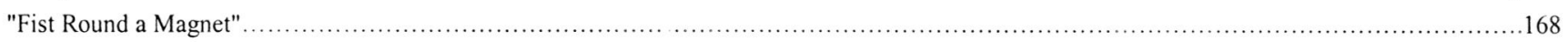

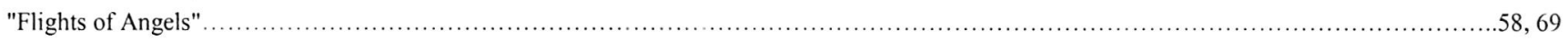

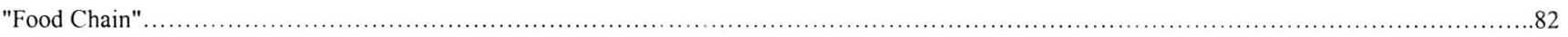

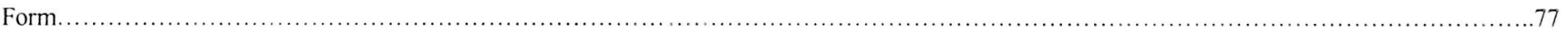

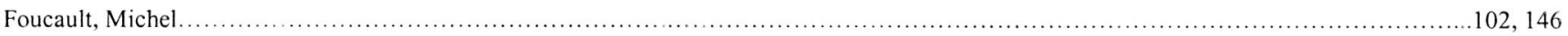

Found words.... 
Frame, Janet.

G

Games....

$12,47,56,84,109,130$

Genre..

$71,85,129$

adventure

boys own.

interview.

...42

pick-a-path .

See Genre, twist-a-plot

twist-a-plot.

$28,71,108,148$

131,133

"Girl Reading"

$4,88,92$

Good Looks...

$51,166,168$

"Good Looks".

$14,16,24,120$

Goon Show, The.

36,179

Graham, Billy.

....88

Graham, James

...62

Grammar.

$71,95,151$

"Grapes".

$.79,168$

Grimm's fairytales

140,143

"Growth".....

"Gull".

Gunn, Daniel

\section{H}

Haiku..

Haines, John.

Hans Christian Andersen

"Hello".

$29,31,33,34,37,38,41,42,56,57,58,69,106,159$

"Hirohito".

History.. $44,47,48,51,52,73,85,113,151,168$

Homelight.

$145,146,148,157$

$76-78,168$

"Hoosh".

$.59,61,64,73,74,75,80,85,87,88,99,103,166,168$

Horrocks,

"Hotere"

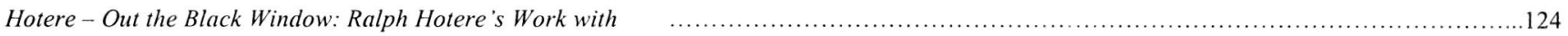

New Zealand Poets

Hotere, Ralph

How To Take Off Your Clothes at the Picnic.

$1,3,5,6,7,79,92,115,124,136,137,138,151,162$

"How To Take Off Your Clothes at the Picnic"

$11-13,25,59,93,100,101,119,133,134,152,166,168$

"How To Take Off Your Clothes at the Picnic:

$13,24,62,79$

Drawings for Bill Manhire"

Hughes, Ted.

Humour....

Hunt, Sam. 
"Hurricane".

Hypertext. .

\section{I}

I, use of. $3,27,59,99,109,119,133,134$

"I Know a Man"

Ignatow, David

Imagery...

$11,3,6,11,12,19,31,32,35,45,50,54,56,59,64,78,79,81,86,87,95$ $99,100,101,109,110,119,129,131,132,134,136$

"In the Studio".

Interconnectedness.

Intertextuality

\section{$J$}

"Jalopy: The End of Love"

\section{K}

Keaton, Buster.

$L$

"La Noche" 
Lauder, Hugh

Layout

$2,5,9,10,24,79,85,90,130,135,151,168,176$

"Leaving Home"

152,168

"Legacies"

.25

Leunig (Australian cartoonist).

.84

"Life With Madame Rosa"

$47,148,151$

Light

75,132

Line-endings

.3, 21

Lines

$7,23,50,71,87,92,93,99,100,109,124,151$

List, Dennis...

166

Lists.

177

"'Listen Nigel"'.

.78

Literal.

129

Literary criticism

151

Literary theory.

157

Logic

13,151

110

Lonie, Alan

.53

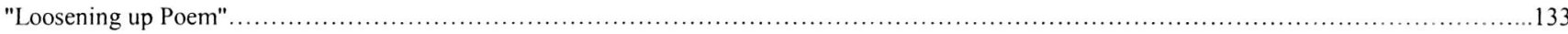

136

"Loss of the Forest"

168

"Love Poem"....

$8,24,62,109,124,134,136,145$

"Luck: A Villanelle"

$79,82,87,96,97,116,154,168,180$

Lyric.

Lyricism.

$. .11,74,93,96,101,114,136,137,169$

$59,79,81,87,95,101,110,119,124,138,149$

M 


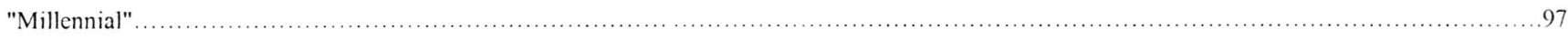

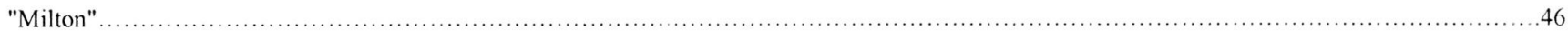

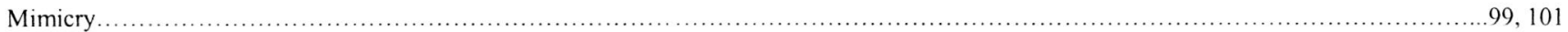

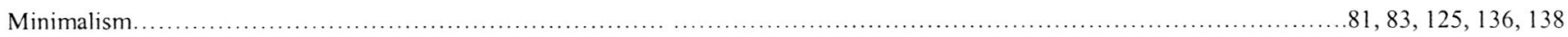

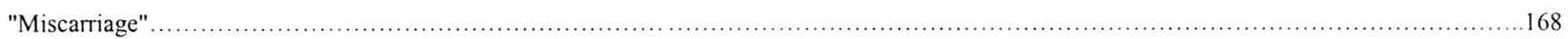

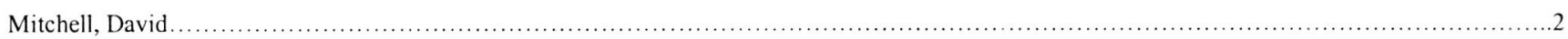

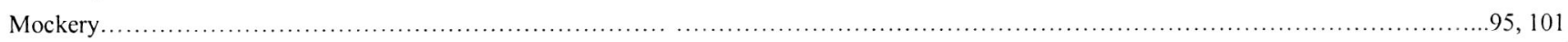

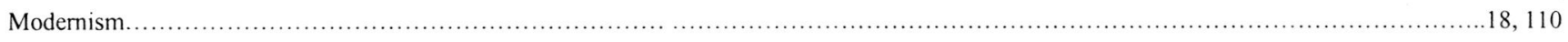

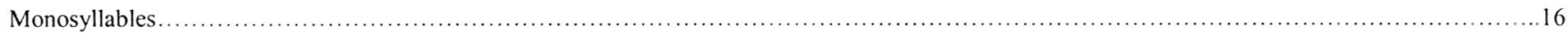

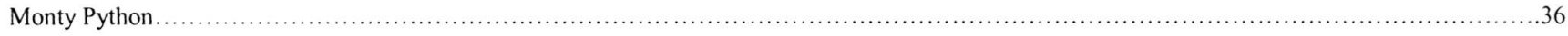

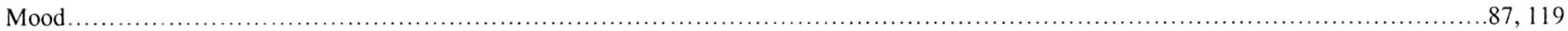

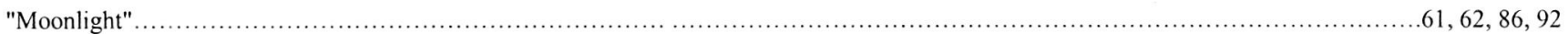

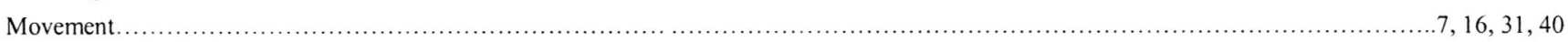

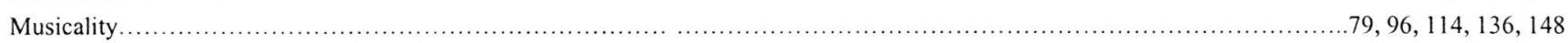

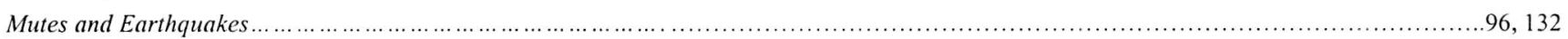

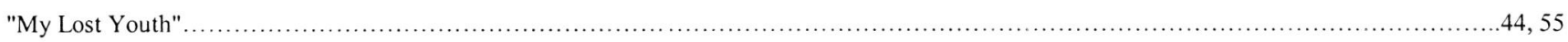

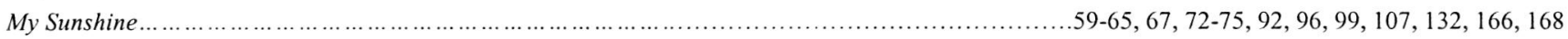

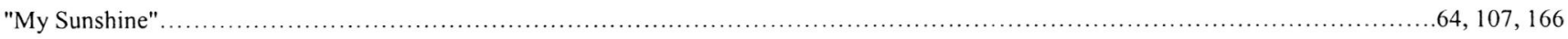

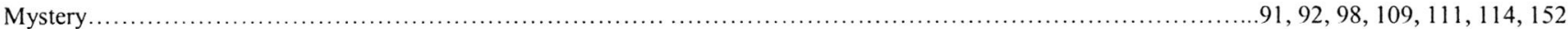

N

Narrative

$19,21,27,37,38,48,56,58,59,93,95,97,114,129,132,134,148,149$

Narrator.

$30,33,164$

Neruda, Pablo

.170

"Nevertheless".

.168

New Zealand

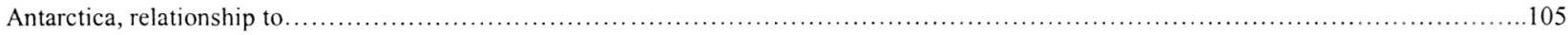

heritage

$38,42,58,61,62,148$

literary stage.

37,159

literary tradition

65,145

use of in writing.

$.13,22,25,26,34,39,40,41,43,48,56,70,71,73,74,86,88,92,96$

$109,118,129,132,135,148,157$

Newton, John

. .96

"Night Windows Carey's Bay"

$133,134,136$

"No Ordinary Sun"

...136

"Nonchalance, or The New Land: A Picture Book"

$31,34,38,42,58,71$

Nonsense...

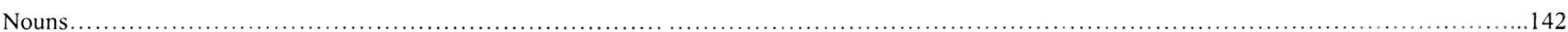

Now See Hear! Exhibition.

.151

Nuclear, anti-

$30,115,138,156$

$\boldsymbol{O}$

Objectivity

O'Brien, Gregory

"Odysseus"...

Olson, Charles.

130,151

"On Originality".

$25,61,62,88,93,95,100,109,132,145,170$

Ondaatje,

.158

Open-form.

.100

Optimism.

...134

Orsman, Chris.

$79,99,117$

"Our Father" 
"Out West".

\section{$P$}

Pain.

Palmer, Michael.

Pathos.

"Pavilion".

$3,6,7,100,123,152$

Penguin Book of New Zealand Verse.

Perec, Georges

Performance

$.21,107$

Pessimism.

"Picnic at Woodhaugh"

$. .79,81$

"Pine".

$124,136,137,138,162$

"Phar Lap"

$45,48,49,51,55,87,157,168,171$

Phrasing.

$3,12,99,101$

Plath, Sylvia

"Pledge".

"Poem"..

"Poem for Vanessa"

Poems

longer

$.24,61,66,73,74,129,132$

shorter.

Poet

as a subject.

Poet laureateship.

$97,128,141,150,154,180$

Poetry File, The

"Ponies".

$30,34,38,41,69,70,118$

Popular culture.

$26,60,95,129,132$

Post-colonialism.

$.43,157,158$

Post-modernism.

$30,43,47,71,74,80,129,157,158,159$

Post-purist.

.184

Pound, Ezra.

$75,164,169$

"Princess: The Treatment"

$47,129,132$

Pronouns..

Pronunciation.

$60,62,91,161$

Pseud's Corner.

168, 169

Publication

....79

Pushkin, anniversary of birth.

\section{$Q$}

Questions.

145,146

Quiet..

$\boldsymbol{R}$

"Ralph Hotere at the Intensity Centre". 
expectations

$12,40,48,95,119$

input of.

$5,6,26,27,95,119,152,170$

positioning.

$129,131,134,159$

relationship with writer

response

$.13,27,32,47,96,97,108,121,127,128,148,153,157$

Realism.

$11,16,18,39,44,55,63,65,86,130$

$30,34,56,62,79,110,155$

"Red Dream"

"Red Horse"

Referents

Register.

$98,99,119,129,144,17$

"Remarkables".

Repetition.

$8,16,60,86,91,113,136,138$

Revision.

Rhetoric

Rhetorical questions

Rhyme.

$78,81,96,166$

Rhythm

$.3,21,55,62,130,148$

Rich, Adrienne.

.159

"Riddle".

$79,109,133,168$

Riddles

$.62,82,133$

Rilke, Rainer Maria

Roethke, Theodore.

$S$

Sadness

$.40,79$

Sandburg, Carl

Satire

$.19,34,37,39,42,49,57,59,70,71,132,148$

Sealy, I. Allan

Second-person.

133,134

Sellers, Peter.

Sharp, Iain

"She Says".

Sheet Music: Poems 1967-1982

$.59-64,67,73,74,96,107,132$

Shelley, Percy Bysshe

Short Back \& Sideways

"Siena".

$29,41,42,58,159$

Signifiers.

$25,27,93,133,157$

Silence......

$60,83,100$

Simic, Charles

Similies..

Simpson, Louis

151,170

Six by Six....

Some Other Country

"Some Questions I Am Frequently Asked".

$31,33,34,35,36,37,38,42,57,58,62,69,70,71,106,138,132,134$

138,163

"Some Screens"

"Song".

Song.......

Song Cycle...

$8,124,136-138,162$

Songs of My Life...

$60,62,65-71,114,129,132$

"Songs of My Life".

$.71,148$

"Sounding the Dark" 
South: An Antarctic Journey

"South Island Companion".

\section{$T$}

Talking of Poets series

Te Mata Estate.

See Poet laureateship

Technology

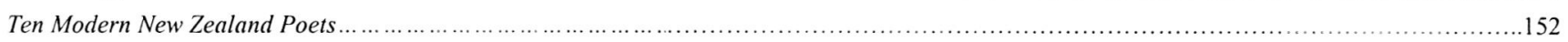

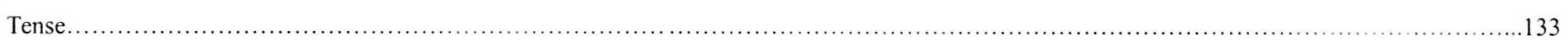

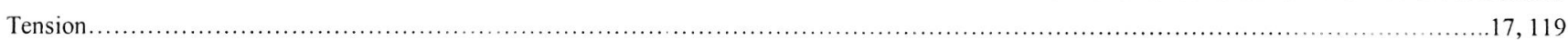

"The Adventures of Hillary".

$.81,95$

"The Afterlife".

$.23,24,25,59,109,110,119,133,134$

"The Album".

$79,82,168$

"The Anglo-Saxon Onion".

$24,109,133,166,168$

"The Asterisk Machine".

$46,148,151$

"The Brain of Katherine Mansfield". $.56-58,60,62,65,70,71,96,98,106,108,114,129,132,135,148,149$

$151,157,159,166$

"The Breakfast Session".

$17,133,134,168$

"The Buried Life"

$17,24,81,93,99$

"The Buried Soap".

"The Calendar"

$. .59,119$

"The Caravan".

$64,133,134$

"The Cinema".

$24,99,123,152,170$

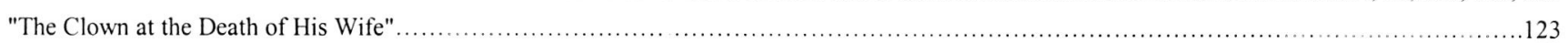

"The Coast"...

"The Collection".

$13,101,119,133,134$

"The Days of Sail".

$33,34,35,40,42,56,58$

"The Distance Between Bodies"

The Elaboration.

$2-7,25,59,86,92,93,99-101,133,134,138,151,152,166,168$

"The Elaboration".

$2,3,7,24,60,100,123$

"The English Teacher" 
"The Gong"

"The Idiot: A Pastoral".

109,119

"The Importance of Personal Relationships".

$13,24,59,100,109$

"The Incision"

$12,133,134,168$

"The Islands"

"The Kiss".

$\ldots 11,168$

"The L \& R Song"

101,133

"The Late Victorian Girl"

$92,109,131,133$

The Magic Faraway Tree

143,172

"The Magpies"

"The Moon at the End of the Century"

"The Mutability Cantos"...

$.12,24,97$

The New Land: A Picture Book.

29-43, 59, 70, 98, 129, 138, 148, 149, 151, 157, 163, 166

"The Next Thousand"

$86,87,92,116,168$

"The Occupation, Against Time"

The Old Man's Example...

$134,138,166,168$

"The Old Man's Example".

"The Oreti River"

"The Paperweight"

"The Pickpocket"

$24,95,96,98,99,119,123,152,164$

"The Poetry Reading"

$91,93,95,133$

"The Poet's Wife".

$58,60,70,71$

"The Polar Explorer's Love Song"

$78,79,81,105,168$

"The Prayer".

$3,25,59,101,134$

"The Procedure"

101,152

"The Proof".

..3, 123

"The Proposition"

59,170

"The Riddle".

"The River"...

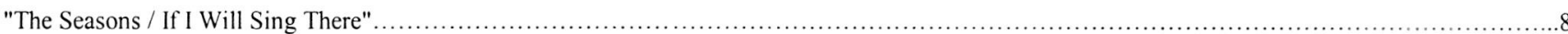

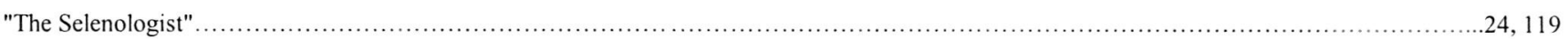

"The Snow".

"The Song".

$11,24,95,101,119,168$

"The Spell"

...4, 101, 133

"The Swallow".

$18,95,109,119,129,132,133,168$

"The Trees".

$101,131,134$

"The Voyage"

$8,101,124,136,137$

"The Voyeur: An Imitation"

"The White Pebble"

$24,92,95,109,110,119,133,134$

"The Wind"

$5,60,168$

The Young New Zealand Poets....

$8,124,136,137,138$

Theft.

See Technique, found words

Themes.

..86, 101, 119, 146, 155

$30,64,72,78,88$

Antarctica

...119

$.53,72,100,128,135$

communication.

death.

$20,99,119$

domesticity

$24,79,128,129,149$

family

129,133

friends...

$. .17,100$

future.

....20

human predicament.

$20,24,50,69$

internationalism. 


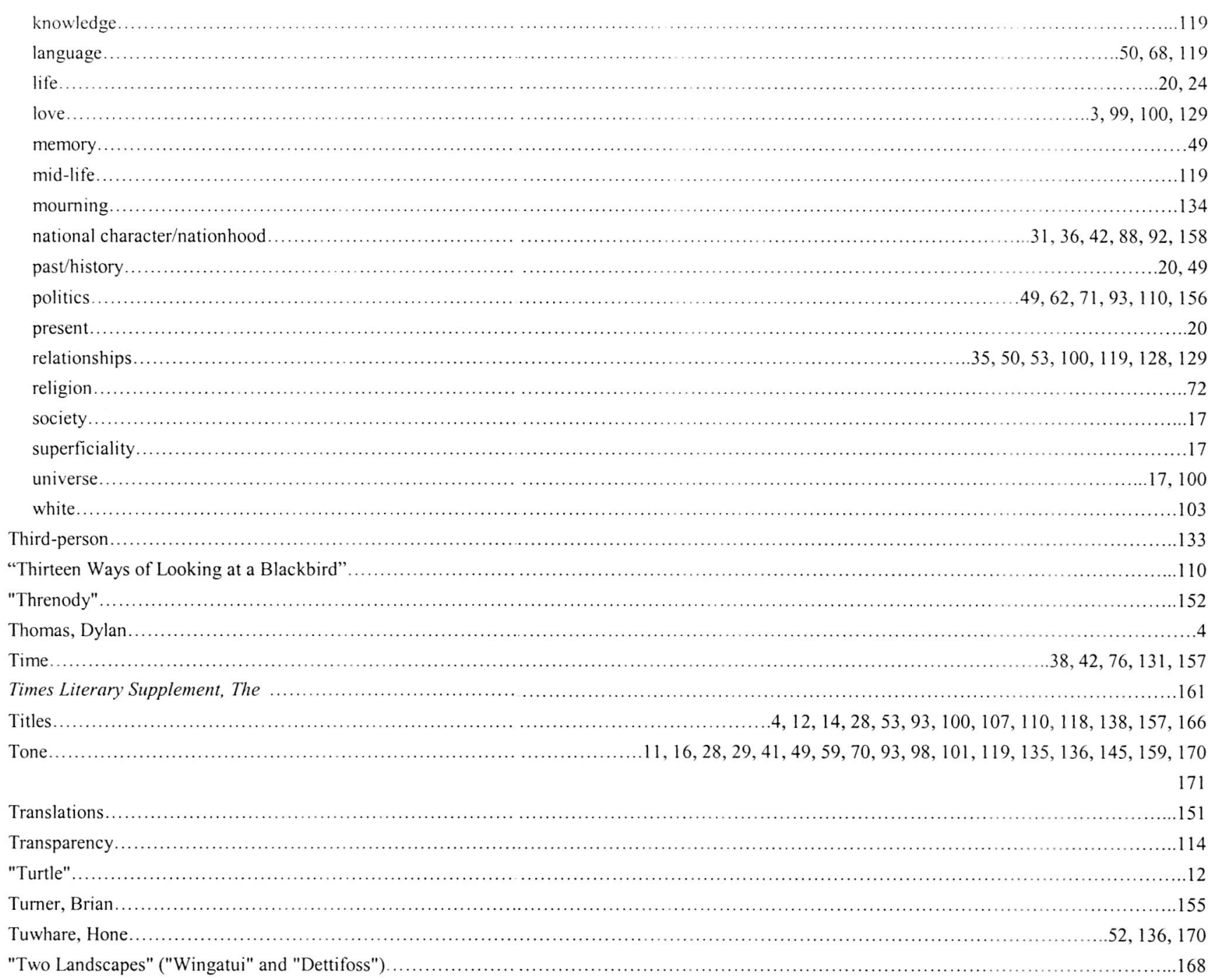




\section{$W$}

Walcott, Derek

"Watching Alison in Winter"

$.86,101$

"Water, A Stopping Place"

$.22,91,93,110,131,134$

We, use of

16,134

Wedde, Ian

$25,98,99,101,110,133,134,157,158,164,170,184$

"Wellington".

$. .19,20,24,92,93,110,116,129,132,133$

Wellington School

See Manhire School

"Wen".

$109,133,168,175$

"What it Means to be Naked"

What to Call Your Child..

$. .79-84,95-97,128,132,168$

"What to Call Your Child"

$79,87,96$

"When You're Dead You Go on Television".

$14,24,135$

Whitman, Walt

$12,147,170$

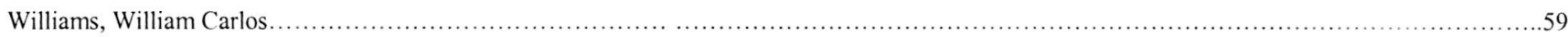

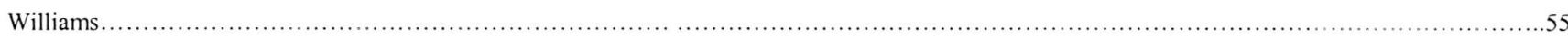

"Wingatui" ("Two Landscapes")..................................................60, 62, 86, 91, 92, 110, 129, 132, 151, 157, 159, 161, 168

"Wings".

"Wings of Gold: A Week Among Poets"

Women, portrayal of

$56,57,60,62,65,67,69,71,129,130,132,150,159$

Wright, James.

Writer

presence in poems

"Wulf".....

$\boldsymbol{Y}$

Yeats, W. B.

You, use of.

$17,27,59,93,99,119,133,134,170$

"You: A Fragment".

$.20,119$

"Your Absence"

"Your Room"

$Z$

Zoetropes 